\title{
Protocolo Otimista Time Warp para Sincronização de Simulação Distribuída Orientada a Eventos
}

\author{
Regiane Yumiko da Silva Kawasaki
}

Orientadora: Profa. Dra. Regina Helena C. Santana

Dissertação apresentada ao Instituto de Ciências Matemáticas e de Computação da Universidade de São Paulo - ICMC/USP, como parte dos requisitos para a obtenção do título de mestre em Ciências - Área: Ciências de Computação e Matemática Computacional.

USP - São Carlos

Dezembro/1998 
"A vida se contrai e se expande proporcionalmente à coragem do indivíduo" (Anaïs Nin) 
A Renato Francês, a pessoa mais admirável que conheço...Todo o meu Amor. 


\section{AGRADECIMENTOS}

A Deus, pela infinita bondade de me mostrar que os obstáculos são sempre superáveis, mesmo quando as saídas parecem ser um pouco nebulosas.

Aos meus pais, Maria Cleide e Kotaro Kawasaki, que me ensinaram através de gestos e palavras o verdadeiro sentido do amor, dedicação e respeito. E que, apesar de todas as dificuldades impostas pela vida, conseguiram proporcionar aos fillhos uma educação digna.

À Profa. Regina Helena Carlucci Santana, pela compreensão e pela orientação, e principalmente pelo crédito que me concedeu durante todo o período do mestrado, sempre de maneira cordial.

Ao Prof. Marcos Santana, que contribuiu para uma melhor delimitação e estruturação deste trabalho.

Aos meus irmãos, pelo companheirismo e pelos incentivos sempre presentes quando eu mais precisei.

À Cleise e Alex, pela grande amizade que só os verdadeiros amigos demonstram em cada atitude. Obrigada pela agradável convivência.

Aos amigos Rita e Flávio, pelo respeito e sinceridade que demonstraram desde o início da nossa amizade.

À Adriana, pelas conversas descontraidas e pelas dicas valiosas que me ajudaram bastante a chegar ao término deste trabalho.

Aos colegas da portaria, pela simpatia e educação que sempre demonstraram.

À CAPES, pelo apoio financeiro, que se constituiu em elemento fundamental para essa pesquisa, e que, infelizmente, os futuros recém-graduados não poderão usufruir.

Às amigas da secretaria da Pós-Graduação Beth, Laura e Marília, por fazerem sempre o possível para ajudar a todos os alunos.

A todas as pessoas que contribuíram de maneira direta ou indireta com a realização deste trabalho. 


\section{ÍNDICE}

ÍNDICE

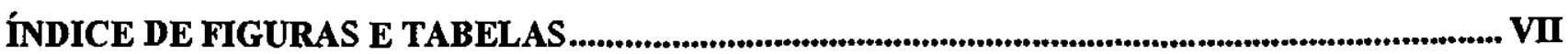

TABELA DE ABREVIATURAS.................................................................................................................IX

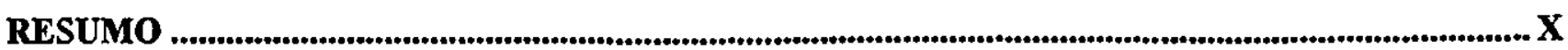

ABSTRACT

CAPÍTULO 1. INTRODUÇÃO_.........................................................................................................................

CAPÍTULO 2. SIMULAÇÃO.........................................................................................................6

2.1. INTRODUÇÃO

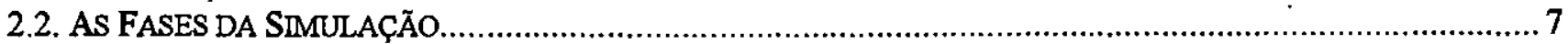

2.3. DESENVOLVIMENTO DE UM MODELO PARA SIMULAÇÃO ............................................................... 11

2.3.1. Simulação Orientada a Evento.......................................................................................... 13

2.3.2. Simulação Orientada ao Exame da Attvidade....................................................................... 15

2.3.3. Simulação Orientada a Processo …………………….....................................................16

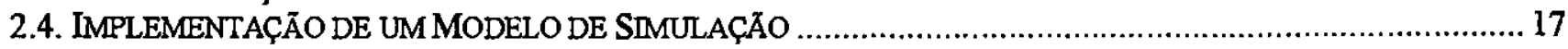

2.4.1. Linguagens de Programação Convencionais........................................................................ 18

2.4.2. Linguagens de Simulação .............................................................................................. 18

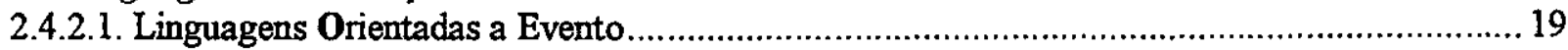

2.4.2.2. Linguagens Orientadas ao Exame da Atividade................................................................ 19

2.4.2.3. Linguagens Orientadas a Processo ………………………................................................ 19

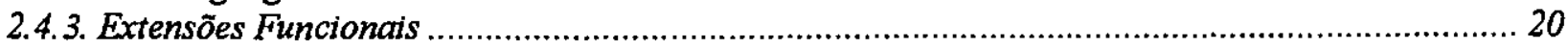

2.4.4. Pacotes de Simulação de Uso Especifico................................................................................. 20

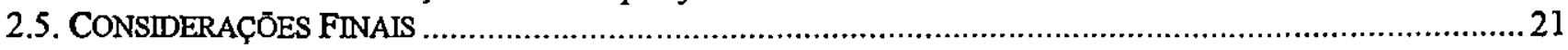

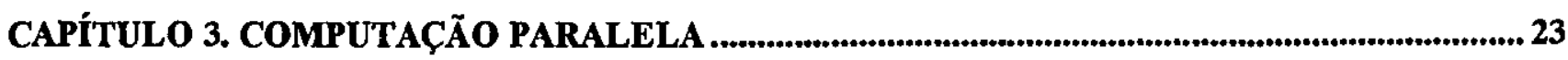

3.1. INTRODUÇÃO

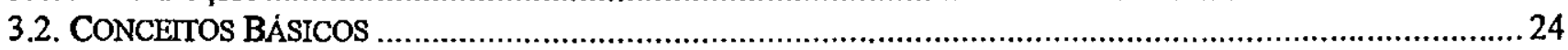

3.3.1. Tipos de Paralelismo ............................................................................................... 24

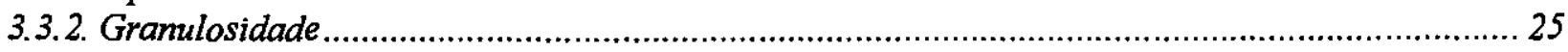

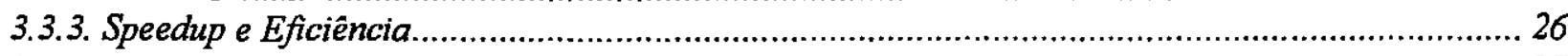

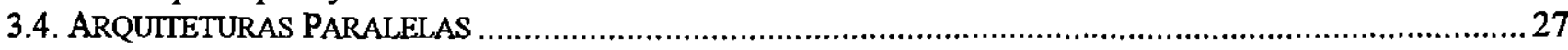

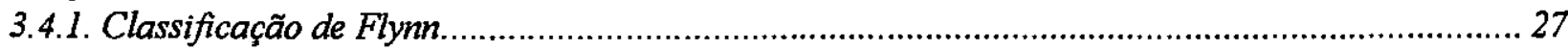

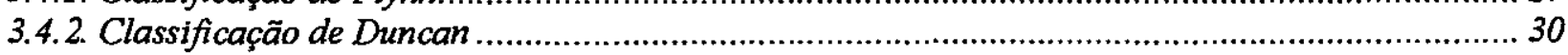

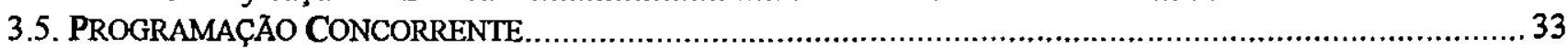

3.5.1. Declaração de Processos Concorrentes .................................................................................. 34

3.5. 2. Comunicação e Sincronismo ................................................................................................. 37

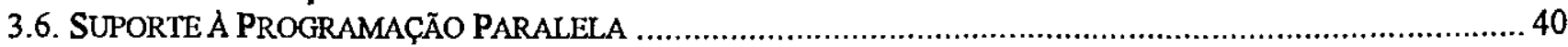

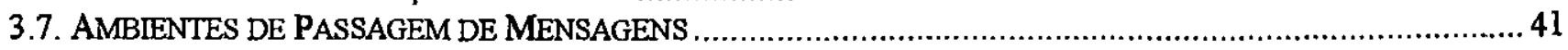

3.8. EXEMPLOS DE AMBIENTES DE PASSAGEM DE MENSAGENS ..........................................................4

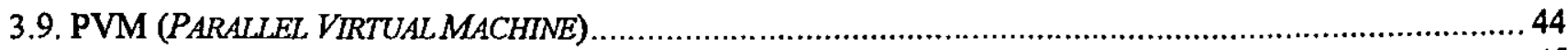

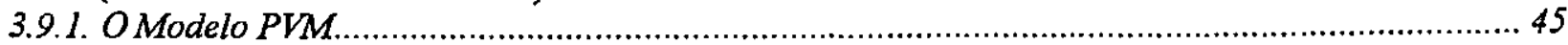




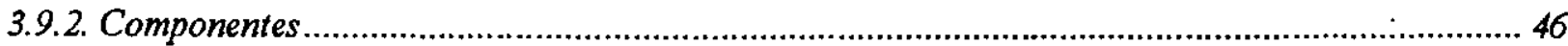

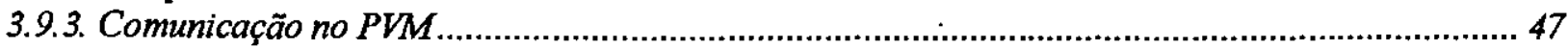

3.9.4. PVM em Sistemas com Multiprocessadores............................................................................. 49

3.9.5. Importância da Utilização do PVM.......................................................................................... 49

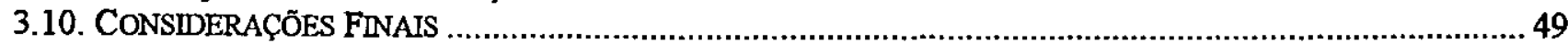

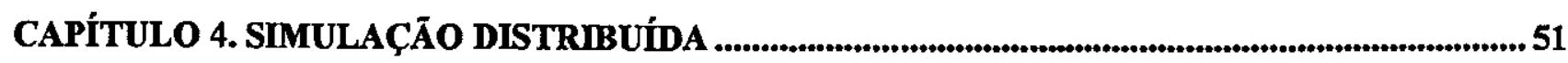

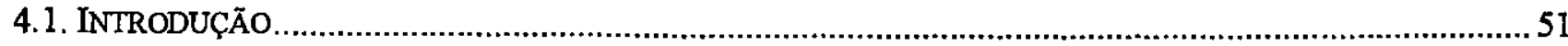

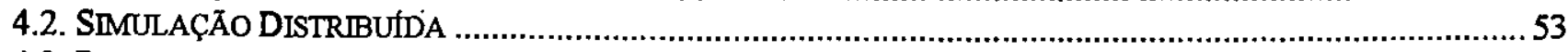

4.3. PROTOCOLOS PARA SINCRONIZAÇÃO EM SIMULAÇÃO DISTRIBỨDA..................................................... 55

4.3.1. O Protocolo CMB (Prevenção de Deadlock utilizando Mensagens Nulas)................................. 55

4.3.2. Transmissão de Mensagens Nulas Sob Demanda .................................................................... 58

4.3.3. Detecção e Recuperação do Deadlock .................................................................................. 60

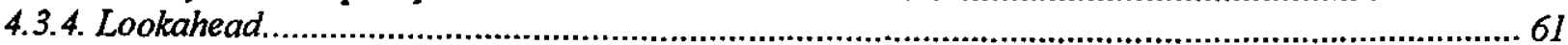

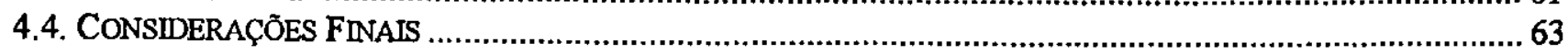

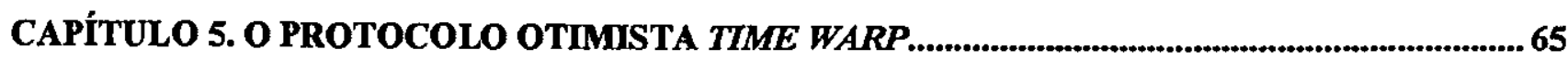

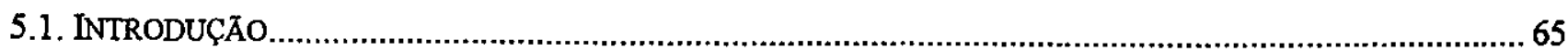

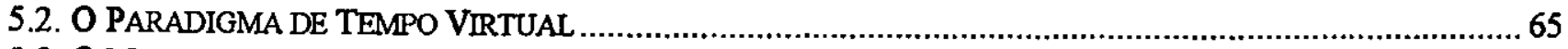

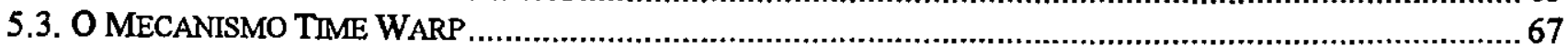

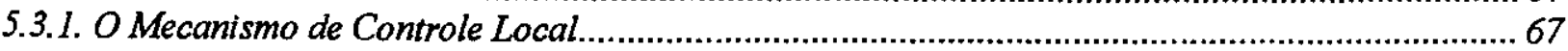

5.3.2. O Mecanismo de Controle Global............................................................................................ 74

5.3.2.1. Uso de GVT para Gerenciamento de Memória e Controle de Fluxo............................. 75

5.3.2.2. Entrada e Saída ......................................................................................................... 76

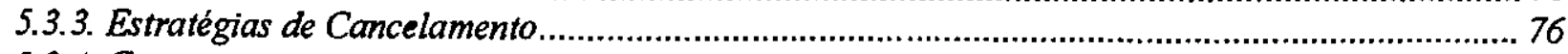

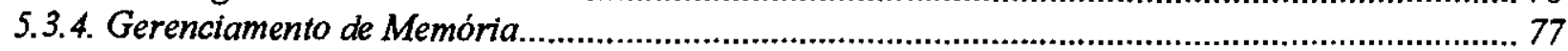

5.3.4.1. Esquemas que Reduzem a Média de Memória Utilizada ...................................................... 78

5.3.4.2. Esquemas que Recuperam Memória "Sob Demanda" ......................................................... 79

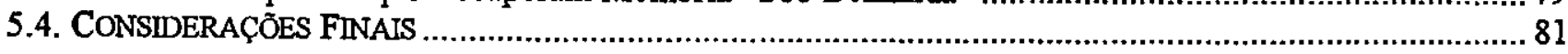

CAPÍTULO 6. PROJETO E IMPLEMENTAÇÃO DO SISTEMA TIME WARP (STW)..................... 82

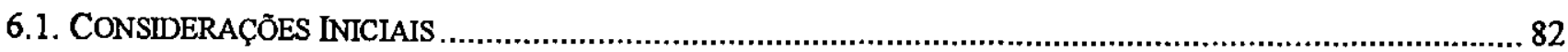

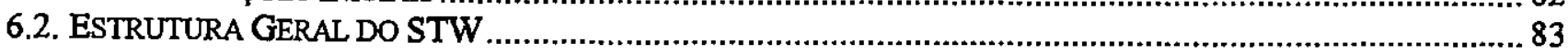

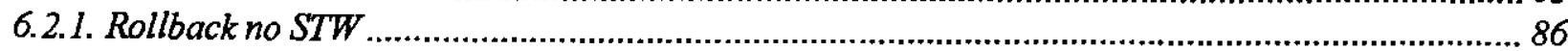

6.2.2. Estratégia de Cancelamento no STW …................................................................................ 88

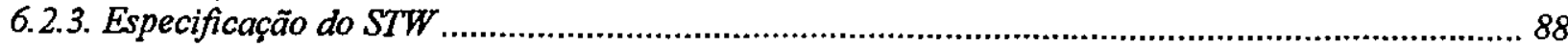

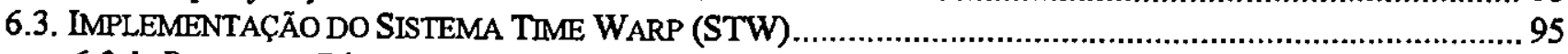

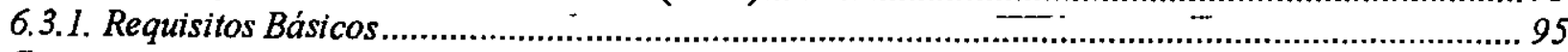

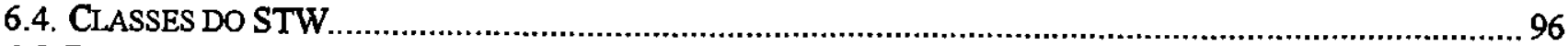

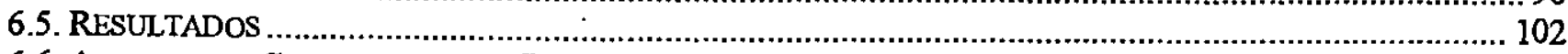

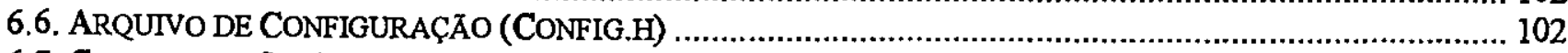

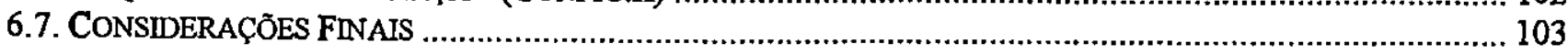

CAPÍTULO 7. ESTUdO DE CASO E ANÁlISE DOS RESULTADOS.............................................. 105

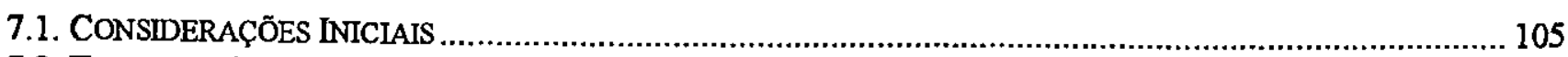

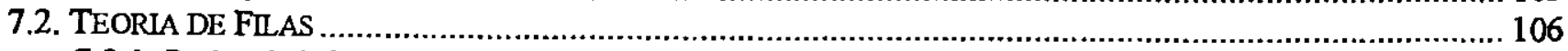

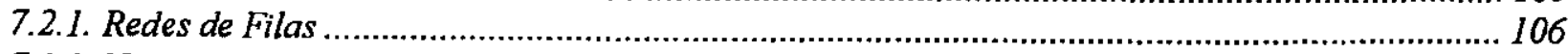

7.2.2. Notação para Sistemas de Filas ..................................................................................... 108

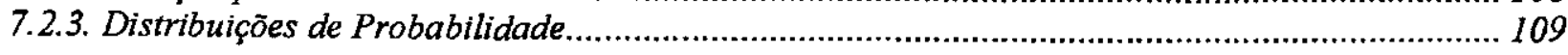


7.2.4. Disciplinas de Atendimento aos Clientes........................................................................... 110

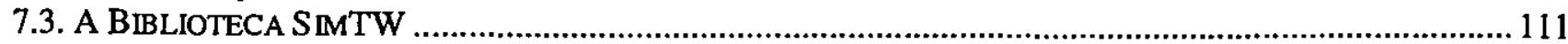

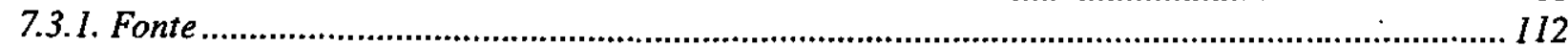

7.3.2. Fork

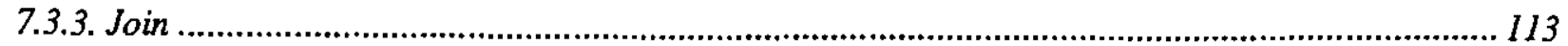

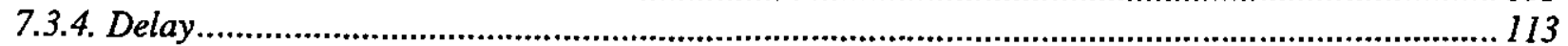

7.3.5. Fila

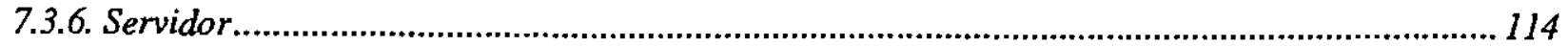

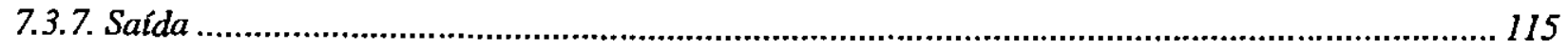

7.4. INSTANCIAÇÃO DOS OBJETOS DA BIBLIOTECA SIMTW.................................................................. 116

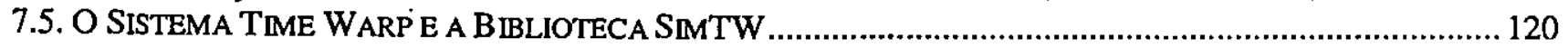

7.6. ESTUDO DE CASO: STW COMO MODELO DE SIMULAÇĀO................................................................. 122

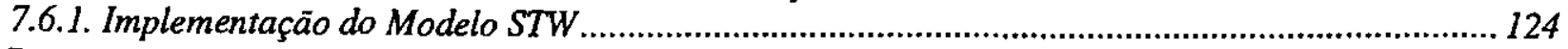

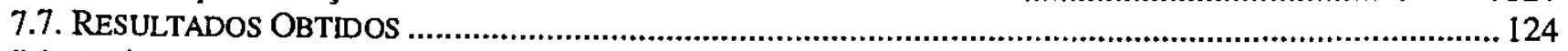

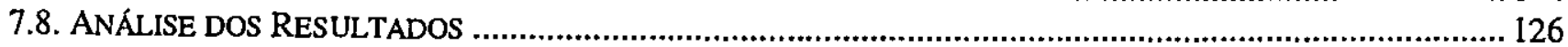

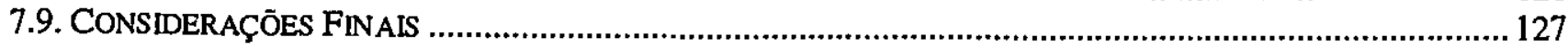

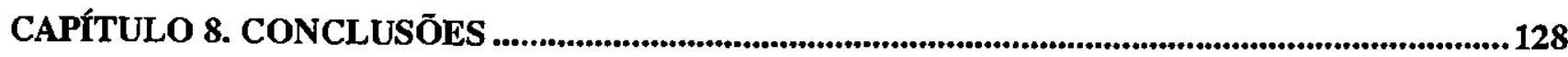

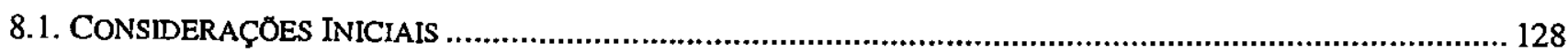

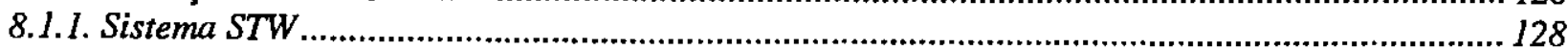

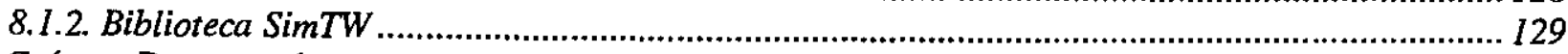

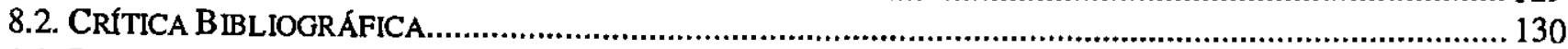

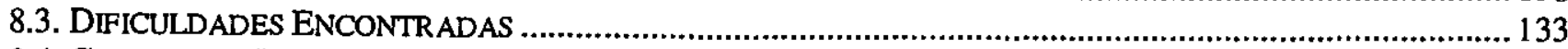

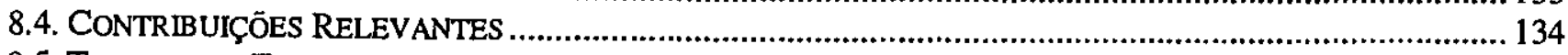

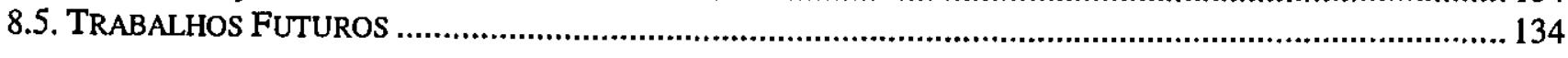

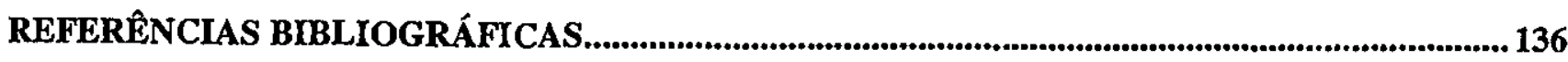

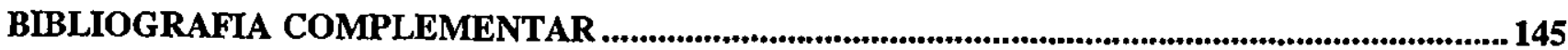




\section{ÍNDICE DE FIGURAS E TABELAS}

FIGURA 2.1 - VARIÁVEL DEPENDENTE EM UM MODELO DISCRETO .........................................................9

FIGURA 2.2 - VARIÁ VEL DEPENDENTE EM UM MODELO CONTINUO ….....................................................9

FIGURA 2.3 - RELAÇÕES ENTRE EVENTO, PROCESSO E ATTVIDADES ...................................................... 11

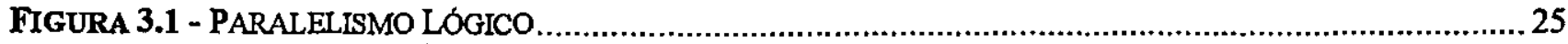

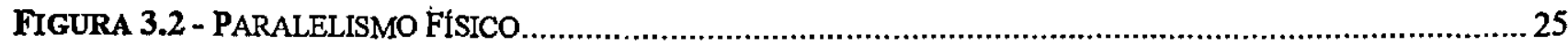

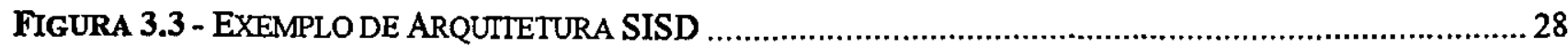

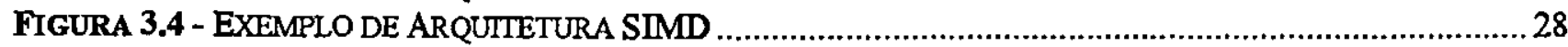

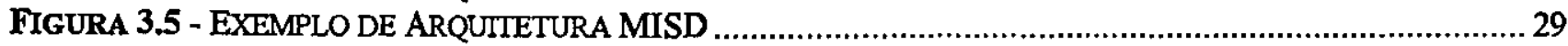

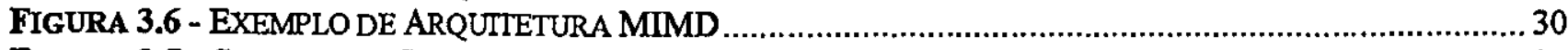

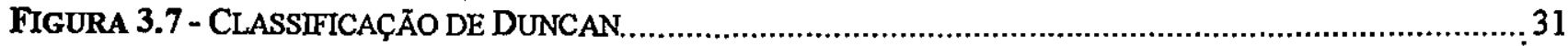

FIGURA 3.8 - ARQUTTETURAS MIMD. (A) MEMÓRIA COMPARTIL HADA (B) MEMÓRIA DISTRIBUIDA .......... 32

FIGURA 3.9 - EXEMPLO DA UTILIZAÇÃO DOS COMANDOS FORK/JOIN ............................................. 35

FIGURA 3.10 - EXEMPLO DA UTILIZAÇÃO DOS COMANDOS COBEGIN/COEND ..................................... 35

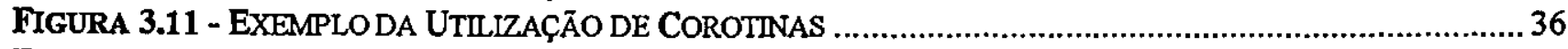

FIGURA 3.12 - EXEMPLO DA UTILIAÇÃO DO DOALL …..................................................................... 37

FIGURA 3.13 - PRIMITIVAS SEND/RECEIVE. (A) BLOQUEANTE (B). NÃO BLOQUEANTE................................. 38

FIGURA 3.14 - MECANIMMOS DE COMUNICAÇÃO. (A) PONTO A PONTO (B) RENDEZVOUZ ........................... 39

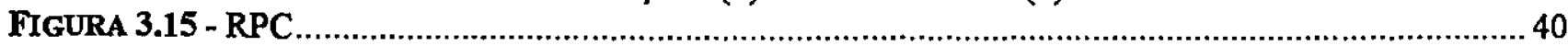

FIgURA 3.16 - SisTEMA PVM. (A) MODELO COMPUTACIONAL (B) VISÃo ARQUTIETURAL......................... 46

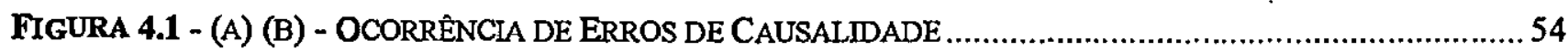

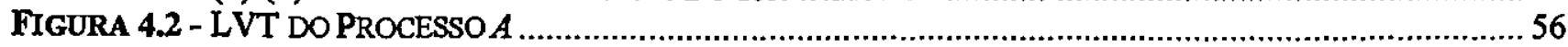

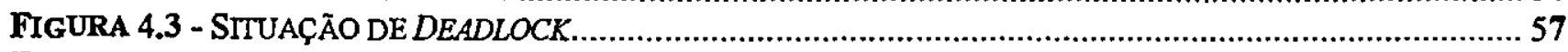

FIGURA 4.4 - (A) (B) TRANSMISSÃo DE MENSAGENS NULAS SOB DEMANDA ..............................................5 59

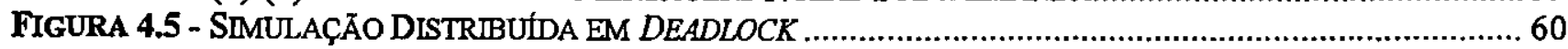

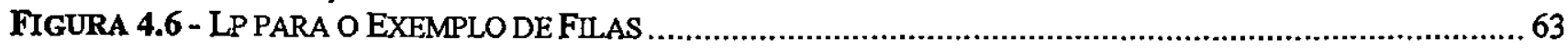

FIGURA 5.1 - UM PROCESSO TIME WARP ................................................................................... 70

FIGURA 5.2 - ROLLBACK PARA O TEMPO 135 .............................................................................. 72

FIGURA 5.3 - RELAÇÃO ENTRE OS VALORES DO TEMPO DE SIMULAÇÃO ................................................ 74

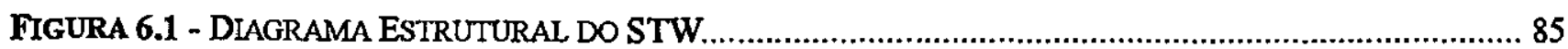

FIGURA 6.2 - OCORRÊNCIA DE VIOLAÇÃO DE CAUSALIDADE ......................................................... 87

FIGURA 6.3 - MECANISMO DE ROLLBACK E ANTIMENSAGENS ……....................................................... 87

FIGURA 6.4 - ELEMENTOS BÁSICOS DE UMA REDE DE PETRI ............................................................ 89

FIGURA 6.5 - PROTOCOLO SIMPLES DE COMUNCAÇÃO EM REDE DE PETRI ..............................................8 89

FIGURA 6.6 - MODELO EM REDE DE PETRI PARA STW, UTIIIZANDO O CANCELAMENTO AGRESSIVO ........... 90

FIgURA 6.7 - MODEL EM REDE dE PETRI PARA STW, UTILIZANDO O CANCELAMENTO PREGUÇOSO ........ 93

FIGURA 7.1 - UM CENTRO DE SERVIÇO COM UM ÚNICO SERVIDOR.................................................... 107

FIGURA 7.2 - MÚLTIPLOS CENTROS DE SERVIÇO COM APENAS UM SERVIDOR ....................................... 107

FIGURA 7.3 - REPRESENTAÇÃO GRÁFICA DE UM SISTEMA BANCÁRIO .............................................. 115

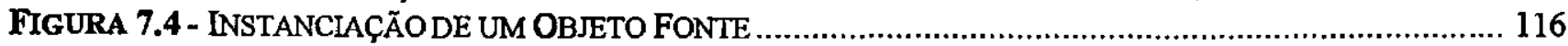

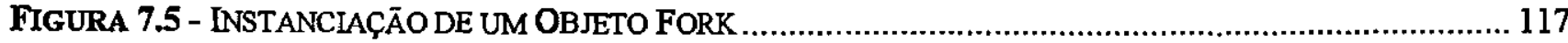

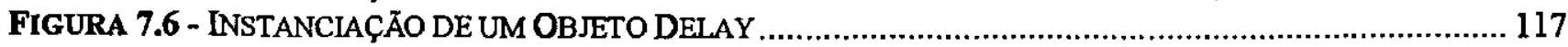

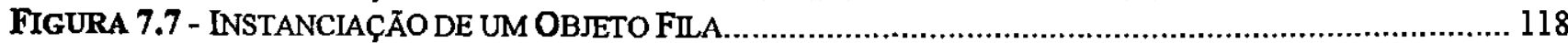




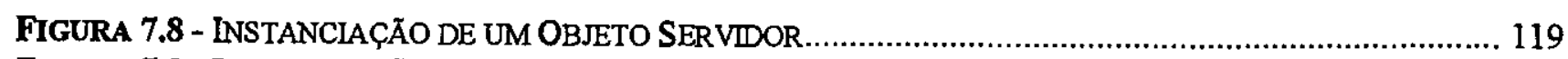

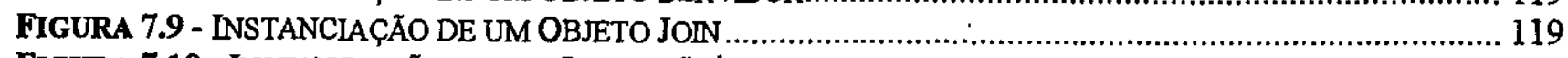

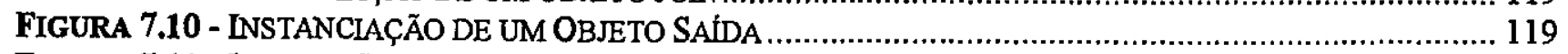

FIGURA 7.11 - INTERAÇÃo ENTRE A APLICAÇÃO DO USUÁRIO, A BIBLIOTECA SIMTW,

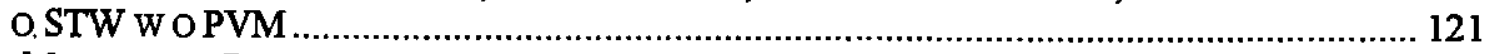

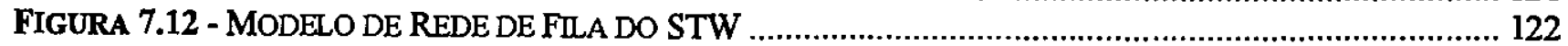

FIGURA 7.13 - GRÁFICO DE COMPARAÇÃo ENTRE TEMPOS DE SIMULAÇĀO DO CANCEL_AMENTO AGRESSIVO, CANCELAMENTO PREGUIÇOSO E SEQUENCIAL ................................................. 126

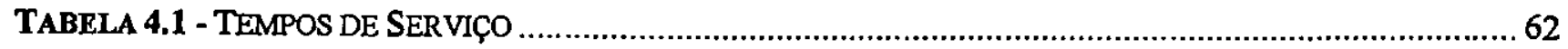

TABELA 6.1 - ELEMENTOS QUE COMPÕEM UM PROCESSO STW ............................................................8 84

TABELA 6.2 - TABELA DE LUGARES DOS PROCESSOS TRANSMISSOR E RECEPTOR

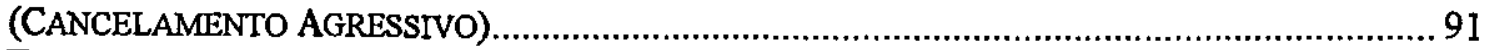

TABELA 6.3 - TABELA DE TRANSIÇÕES DOS PROCESSOS TRANSMISSOR E RECEPTOR

(CANCELAMENTO AGRESSIVO) ................................................................................ 91

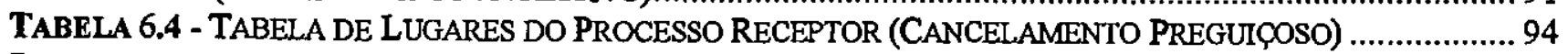

TABELA 6.5 - TABELA DE TRANSIÇŌES DO PROCESSO RECEPTOR (CANCEI_AMENTO PREGUIÇOSO) ............... 94

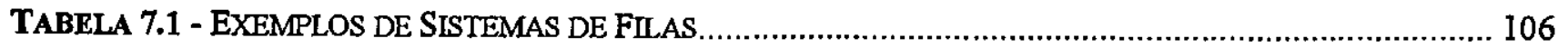




\section{TABELA DE ABREVIAÇÕES}

\begin{tabular}{|c|c|c|}
\hline Abreviaturation & $\begin{array}{l}3 \\
3\end{array}$ & 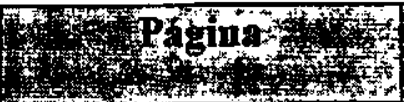 \\
\hline CMB & Chandy, Misra e Bryant & 2 \\
\hline PVM & Parallel Virtual Machine - Máquina Paralela Virtual & 3 \\
\hline STW & Sistema Time Warp & 5 \\
\hline MPI & $\begin{array}{c}\text { Message Passing Interface - Interface de Passagem de } \\
\text { mensagens }\end{array}$ & 34 \\
\hline $\mathbf{L p}$ & Processo Lógico & 44 \\
\hline $\mathbf{P p}$ & Processo Físico & 44 \\
\hline LVT & Tempo Virtual Local & 45 \\
\hline GVT & Tempo Virtual Global & 61 \\
\hline
\end{tabular}

OBS: Algumas abreviações utilizadas ao longo desta dissertação. 


\section{RESUMO}

Este trabalho aborda o problema de sincronização entre processos em uma simulação distribuída orientada a eventos. Dentre os mecanismos voltados à sincronização entre processos, propostos na literatura, optou-se pela abordagem otimista Time Warp.

O trabalho enfoca a dificuldade de processamento que um modelo de um sistema real resolvido por simulação seqüencial pode vir a apresentar. Com o intuito de minimizar o tempo de execução de uma simulação seqüencial, vem-se adotando a simulação distribuída. No entanto, a utilização desta técnica introduz outros problemas, entre eles, o problema de sincronismo entre processos.

Um sistema que descreve o funcionamento do mecanismo Time Warp é desenvolvido. Esse sistema, chamado STW, incorpora alguns algoritmos que otimizam a utilização do mecanismo Time Warp. As otimizações introduzidas no sistema são a estratégia de cancelamento agressivo e o cancelamento preguiçoso.

Uma biblioteca destinada à construção de modelos de sistemas de filas, denominada SimTW, é implementada e utilizada no estudo de caso. O modelo utilizado pelo estudo de caso é o STW. Os resultados obtidos com a simulação desse modelo indicam uma análise comportamental das otimizações introduzidas no sistema STW. 


\section{ABSTRACT}

This dissertation focuses on the interprocess synchronization problem in distributed discrete-event simulation. The literature presents several approaches for interprocess synchronization and in this work the Time Warp optimistic approach is adopted.

The work discusses the processing power demand presented by sequential simulation. In order to minimize running time of sequential simulation, distributed simulation has been adopted. However, the utilization of these techniques introduces some other questions, such as, the interprocess synchronization problems.

A system that implements the Time Warp approach is developed. This system, named STW, aggregates some algorithms that optimize the use of the Time Warp approach. Some optimizations are introduced in the system, including: Lazy and Aggressive Cancellation Strategies.

A library which the aims of providing the ways for building models of queuing systems (SimTW) is implemented and used in a case study. The model used to validate the case study represents the STW. The results obtained through the model simulation show a behavioral analysis of the optimizations introduced into the STW. 


\section{Capítulo 1}

\section{Introdução}

A evolução dos sistemas computacionais, desde a sua origem até os dias atuais, tem perseguido duas metas básicas: desempenho e confiabilidade. Em termos de confiabilidade, têm-se atualmente técnicas que aumentam a disponibilidade e a segurança dos sistemas computacionais. Em desempenho, observou-se um dos mais rápidos desenvolvimentos tecnológicos da história da computação. Um assunto que vem preocupando os projetistas e usuários de sistemas computacionais é a análise de desempenho desses sistemas. A avaliação de desempenho vem se tornando mais atrativa, uma vez que esta indica a qualidade do trabalho executado pelo sistema, e é de vital importância na seleção de sistemas alternativos, no projeto de novos sistemas e na análise de sistemas existentes (Morselli, 1995).

Diversas ferramentas têm sido utilizadas para avaliação de desempenho de sistemas, sendo que a escolha entre essas ferramentas depende fundamentalmente do objetivo da avaliação em andamento e do tipo de avaliação desejada (Santana, 1994). Para exemplificar essa afirmação acima, pode-se citar a comparação de diversas máquinas disponíveis no mercado. Neste caso, as arquiteturas a serem avaliadas existem e podem-se utilizar monitores de hardware, monitores de software, benchmarks ${ }^{3}$, entre outros. Já para o caso em que se deseja avaliar um projeto em que a máquina ainda não está disponivel, as técnicas mencionadas no anteriormente se tornam menos adequadas. Nesse caso, a utilização de modelos resolvidos por simulação pode auxiliar no entendimento do projeto, na sua validação e na avaliação do desempenho que será obtido (Swain, 1995). Uma outra situação em que a simulação pode ser utilizada com vantagens é na avaliação de modificações em

\footnotetext{
${ }^{1}$ Monitores de hardware são hardware especificos empregados para coletar e analisar alguns dados pertinentes ao objeto em estudo (Orlandi, 1995).

${ }^{2}$ Monitores de software são usados nos casos em que se deseja observar características especificas de software, como por exemplo a verificação da existência ou inexistência de uma fila de espera associada a um recurso do sistema. Essas características muito peculiares ao software não poderiam ser detectadas por monitores de hardware (Orlandi, 1995).

${ }^{3}$ Benchmarks são padrões de desempenho, ou seja, programas usados para testar o desempenho de software ou hardware ou um sistema computacional (Collin, 1993).
} 
arquiteturas existentes. Essa técnica é capaz de responder de forma tanto quantitativa quanto qualitativa às perguntas (e se?) feitas constantemente pelos projetistas de sistemas. Como exemplo dessa situação pode-se citar a avaliação da influência de um processador duas vezes mais rápido no desempenho de uma máquina. Assim, pode-se obervar que simulação é uma ferramenta flexível e que pode ser utilizada em diferentes situações. Algumas vantagens enicontradas na utilização da simulação são apresentadas a seguir:

- Flexibilidade: a simulação se baseia em um programa que pode ser facilmente alterado, permitindo a verificação de um grande número de alternativas de projeto em um curto espaço de tempo;

- Custo Relativamente Baixo: a simulação não requer que o sistema a ser avaliado exista, dispensando a aquisição de sistemas e componentes de custos elevados, todas as características do sistema são representadas através de um modelo e por um programa de simulação (Soares, 1992).

Apesar de todas as vantagens descritas acima, a implementação de uma simulação não é uma tarefa trivial, como pode parecer em uma análise preliminar. Para que os resultados de uma simulação sejam válidos, inicialmente deve-se ter um modelo que represente o sistema a ser avaliado. A partir desse modelo deve ser construído um programa de simulação. A execução desse programa se baseia na utilização de variáveis aleatórias ${ }^{4}$, o que torna necessária a análise dos resultados para garantir que os dados obtidos sejam válidos, ou seja, obter um alto grau de confiabilidade nas medidas adquiridas (a validação é um processo complexo e é discutida de maneira interessante em (MacDougall, 1987)).

O problema mais crítico relacionado com a simulação se encontra no possível grande esforço computacional necessário para a execução de uma simulação realista. Às vezes, o tempo de processamento chega a ser inviável. Para esses casos, a utilização de simulação distribuída vem, gradativamente, substituindo a simulação seqüencial. A simulação distribuída (Fujimoto, 1990)

\footnotetext{
${ }^{4}$ Varióveis aleatórias são regras de associação de um valor numérico a cada ponto de um espaço amostral. Por exemplo, em um lançamento de duas moedas $(\mathrm{k}=$ cara e $\mathrm{C}=$ coroa), o espaço amostral é $\mathrm{E}=\{\mathrm{KK}, \mathrm{KC}, \mathrm{CK}, \mathrm{CC}\}$ e $\mathrm{KK}$ pode ser associada à variável aleatória de valor 2 (Farias et al., 1991).
} 
(Misra, 1986) explora a utilização de máquinas paralelas com vários processadores e alta capacidade de comunicação (Almasi \& Gottlieb, 1994).

Para possibilitar a utilização de diversos processadores na execução de uma simulação é necessário adaptar a simulação seqüencial para essa nova situação. Um problema crítico na simulação distribuida é o sincronismo entre os processos. A simulação seqüencial se baseia em uma lista de eventos futuros que armazena os eventos a serem executados pela simulação, ordenados pelo tempo em que eles devem ocorrer (MacDougall, 1987). A ativação desses eventos é ordenada por um relógio que controla o tempo de simulação.

O problema da simulação distribuída está na natureza seqüencial da lista de eventos futuros. Nela, um único evento é retirado (do topo da lista) para ser executado; este evento poderá gerar novos eventos com diferentes localizações na lista. Este mecanismo torna dificil a execução concorrente dos eventos, uma vez que a lista de eventos futuros não pode ser simplesmente particionada.

Para solucionar o problema de sincronismo entre os processos de uma simulação distribuída, diferentes protocolos de sincronização têm sido propostos. A maioria deles são extensões dos clássicos $\mathrm{CMB}$ (protocolo conservativo) (Misra, 1986) (Chandy, 1981) e do protocolo otimista Time Warp (Jefferson, 1985).

No protocolo $\mathrm{CMB}$, a estrutura seqüencial imposta pela lista de eventos futuros não é utilizada. A execução segue a ordem imposta pelo tempo real do sistema. O esquema proposto pelo método $\mathrm{CMB}$ garante que um processo só executará um evento quando estiver seguro que todos os eventos, cuja execução pode influenciar o evento em questão, já foram processados. Este protocolo é denominado conservativo e se baseia no bloqueio da execução de eventos. Para evitar a ocorrência de deadlocks por causa do bloqueio, utiliza-se a emissão de mensagens nulas.

O protocolo Time Warp utiliza um mecanismo otimista para a sincronização dos processos. Nesse protocolo, assume-se que o próximo evento disponível no processo em questão pode ser executado. Se após executá-lo, for recebido um evento com tempo de chegada (timestamp) menor que o valor do relógio local do processo receptor do evento, um mecanismo de rollback é utilizado, isto é, o estado anterior à execução do evento deve ser recuperado e mensagens cancelando as erroneamente enviadas são transmitidas. Assim, o novo evento é executado e então o evento que já tinha sido executado é executado novamente. 
O objetivo deste trabalho é desenvolver um sistema que utilize os conceitos que descrevem o protocolo otimista Time Warp. Essa implementação se baseou no conceito de tempo virtual proposto por Jefferson (Jefferson, 1985), culminando no Sistema Time Warp (STW). Esse sistema utiliza alguns algoritmos de otimização propostos na literatura. As otimizações que fazem parte do Sistema Time Warp são o cancelamento preguiçoso e o salvamento (checkpointing) periódico dos estados dos processos. Além dessas otimizações, o cancelamento agressivo, que é a estratégia de cancelamento padrão de qualquer sistema baseado no paradigma Time Warp, também faz parte do STW.

O STW se destina a dois tipos de usuários: aqueles que desejam construir modelos de aplicações distribuídas, tais como simulação distribuída orientada a eventos, e aqueles que desejam apenas experimentar o Time Warp.

Uma biblioteca destinada à construção e simulação de modelos de redes de filas também é desenvolvida neste trabalho. Essa biblioteca, batizada de SimTW, faz parte do estudo de caso apresentado nesta pesquisa. Esse estudo de caso se destina a modelar o funcionamento do sistema Time Warp, através da construção de um modelo de rede de fila. 0 modelo de rede de fila resultante é experimentado e analisado sobre o STW. Os resultados obtidos com a experimentação do modelo implementado no estudo de caso variam de acordo com o tipo de cancelamento e do salvamento (checkpointing) utilizados.

Esta dissertação é organizada em oito capitulos. $\mathrm{O}$ capitulo 2 discute tópicos relevantes e alguns parâmetros relacionados à simulação. Esse capítulo descreve os passos necessários ao desenvolvimento de um processo de simulação, além de citar três alternativas de modelagem que podem ser utilizadas por uma simulação discreta ${ }^{5}$ : (1) modelagem orientada a evento, (2) modelagem orientada ao exame da atividade $e(3)$ modelagem orientada a processo.

o capítulo 3 apresenta os conceitos básicos e as ferramentas necessárias para a implementação de um sistema concorrente. Esse capítulo também aborda os ambientes de programação via troca de mensagens, que visam possibilitar o transporte de programas paralelos entre arquiteturas computacionais distintas. Vários exemplos são expostos, destacando-se o PVM por ser considerado o padrão "de fato" desses ambientes, e por sua utilização neste trabalho.

\footnotetext{
${ }^{5}$ Em uma Simulação discreta, os eventos mudam em pontos especificos (discretos) no tempo.
} 
O capítulo 4 expõe os mecanismos para a implementação de uma simulação distribuída. $O$ protocolo conservativo CMB também é discutido nesse capítulo.

O capítulo 5 aborda o protocolo otimista Time Warp, descrevendo os mecanismos utilizados para detectar e recuperar o sistema, quando ocorre algum conflito. Algumas dificuldades inerentes a esse protocolo são relatadas nesse capítulo.

Os capítulos 6 e 7 descrevem o trabalho desenvolvido nesta dissertação de mestrado. $O$ capítulo 6 apresenta a implementação do sistema STW (Sistema Time Warp). A estrutura comportamental do sistema é explicada. As estratégias de cancelamentos Agressivo e Preguiçoso são descritas com maior riqueza de detalhes. Uma especificação formal, utilizando Redes de Petri, é utilizada para descrever tanto o funcionamento da estratégia de cancelamento agressivo, quanto da estratégia de cancelamento preguiçoso. As principais classes que formam o STW também são apresentadas.

O capítulo 7 apresenta o estudo de caso referente à implementação do sistema Time Warp (STW). Esse capítulo exibe a implementação de uma biblioteca (SimTW) destinada à construção modelos de redes de filas. O estudo de caso manipula o sistema Time Warp, através da construção de um modelo do próprio sistema. Esse modelo é resolvido por simulação, usando para tal objetivo a biblioteca SimTW. Os resultados obtidos com a simulação desse modelo, e a análise desses resultados são abordados no final do capítulo.

O capítulo 8 apresenta as conclusões obtidas com esta pesquisa. Uma breve explanação das principais dificuldades encontradas durante a confecção deste trabalho, além das contribuições desta pesquisa são descritas. Ao final, as propostas para continuidade deste trabalho são citadas.

Finalmente, o capítulo 9 apresenta as referências bibliográficas utilizadas durante o desenvolvimento deste trabalho. 


\section{Capítulo 2}

\section{Simulação}

Este capitulo apresenta algumas definições básicas sobre simulação. Consideram-se os conceitos de orientação a evento, ao exame da atividade e a processo. Também são descritas as fases envolvidas no processo de desenvolvimento da simulação. As linguagens e pacotes disponiveis para simulação são analisados, ressaltando-se as suas vantagens e desvantagens e o processo de construção de um programa de simulação.

\subsection{Introdução}

Semanticamente, a palavra simular significa imitar, fingir (Fernandes, 1993). Seguindo essa definição, pode-se inferir que simulação é a reprodução ou representação do comportamento de um objeto ou sistema. Em computação, a simulação refere-se ao emprego de um processo computacional para implementar um modelo que imite algum fenômeno ou sistemas dinâmicos (sistemas cujos estados se alteram com o tempo) (Orlandi, 1995).

O conceito de simulação, em computação, foi inicialmente proposto por John von Neumann, que visualizou a aplicação da computação para possibilitar a automação de dados estatísticos na modelagem de fenômenos. Isso foi definido como processo Monte Carlo, onde o comportamento do sistema é descrito através de distribuição de probabilidade. Uma distribuição de probabilidade é uma associação de cada valor de uma variável aleatória ao seu respectivo valor de probabilidade.

Desde a década de 60 , a simulação tem apresentado um crescimento significativo em sua metodologia. Por possuir caracteristicas de flexibilidade, facilidade de utilização e custo relativamente baixo, a simulação está sendo cada vez mais empregada em diversas áreas do conhecimento humano (Pedgen, 1991). Como exemplo, pode-se citar sua aplicação em metereologia, sistemas urbanos, sistema ambiental, avaliação de redes de telecomunicações, indústrias siderúrgicas, medicina, engenharia aeronáutica, engenharia nuclear, entre outros. 
Atualmente, na área da computação, a literatura indica que simulação é uma ferramenta que auxilia no projeto, validação e avaliação de desempenho de um sistema real (existente ou apenas em projeto) (Swain, 1995). Dentre os fatores que incentivaram o avanço da simulação nessa área, podem-se citar o desenvolvimento de hardware e as linguagens de programação, que reduziram de certa maneira os esforços necessários para programar um modelo de simulação (Adam, 1979)(Fishwick, 1995).

A simulação pode ser abordada sob diversos enfoques, levando-se em consideração as características do sistema em estudo. A seção 2.2. descreve o desenvolvimento do processo de simulação, a seção 2.3 aborda o desenvolvimento de um modelo para simulação e a seção 2.4 discute a implementação de um modelo de simulação.

\subsection{As Fases da Simulação}

A simulação é uma abordagem geral para o estudo de problemas, geralmente complexos, para os quais não se dispõe de solução analítica. Num contexto mais amplo, a simulação refere-se à construção de modelos de qualquer natureza (fisicos, matemáticos, sistemas produtivos e de distribuição) e simulação de cenários para o apoio à tomada de decisão. Em termos computacionais, a simulação consiste basicamente na execução de um programa de computador, desenvolvido a partir de um modelo do sistema real (existente ou apenas em projeto), reproduzindo o comportamento do sistema e a carga de trabalho a ele submetida (Fernando, 1992).

Dentro de um processo de simulação, os seguintes estágios de desenvolvimento podem ser identificados (Soares, 1992):

1. Estudo do Sistema e Definição dos Objetivos.

2. Construção do Modelo.

3. Determinação dos Dados de Entrada e de Saída.

4. Tradução do Modelo.

5. Verificação (programa $X$ modelo).

6. Validação (modelo $\mathrm{X}$ sistema).

7. Experimentação. 
8. Análise dos Resultados.

9. Documentação.

O primeiro passo na elaboração de uma simulação é composto pelo estudo e entendimento do sistema considerado. O sistema deve ser definido com precisão e as metas pretendidas devem ser claras e objetivas (Maryanski, 1986)(Pedgen, 1991). Uma compreensão errônea dos objetivos da simulação pode determinar conseqüências desastrosas para o estudo, chegando a provocar que todo o processo seja refeito.

Depois de estudar o sistema e definir os seus objetivos, inicia-se o processo de construção do modelo. Um modelo é uma abstração de um sistema, e representa uma visão particular do mesmo. $O$ modelador deve conhecer bem a estrutura e as regras de operação do sistema, sabendo extrair o essencial do sistema, sem incluir detalhes desnecessários. $O$ modelo deve ser de fácil compreensão, mantendo, contudo, uma complexidade tal que reflita realisticamente as características importantes do sistema real (Morselli, 1995).

A natureza de um sistema é avaliada de acordo com as mudanças (alterações) nas suas variáveis de estado. O tempo, na maioria das simulações, é a principal variável independente. As outras variáveis incluidas na simulação são funções do tempo e, portanto, são variáveis dependentes. As mudanças podem ser discretas ou contínuas (dependendo do sistema a ser modelado), gerando duas técnicas básicas para modelagem de sistemas estocásticos ${ }^{6}$ (Soares, 1992):

Modelo de mudança discreta (ou modelo discreto) é aquele em que as variáveis dependentes variam discretamente em pontos específicos do tempo simulado, referidos como tempo de evento, conforme apresentado na figura 2.1 .

\footnotetext{
${ }^{6}$ Sistemas estocásticos são aqueles que variam com o tempo (Soares, 1992).
} 


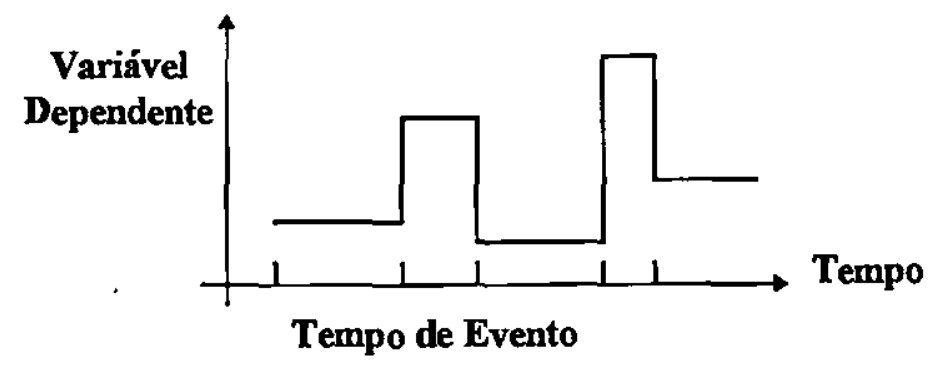

Figura 2.1 - Variável Dependente em um Modelo Discreto.

Modelo de mudança contínuo (ou modelo contínuo) é aquele em que as variáveis dependentes podem variar continuamente ao longo do tempo simulado, conforme apresentado na figura 2.2 .

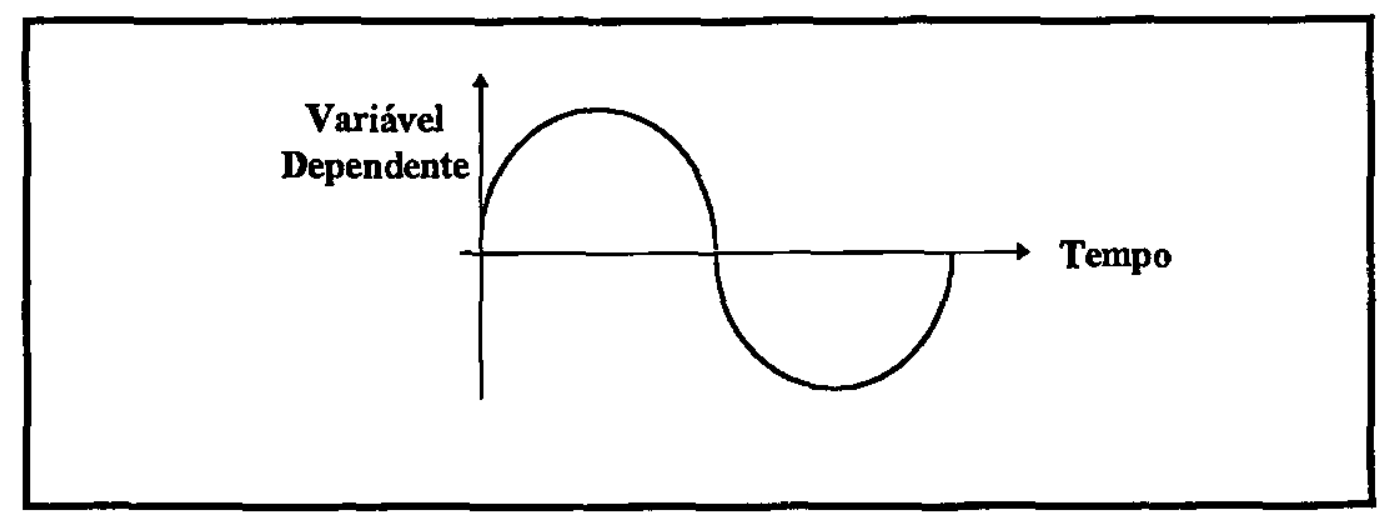

Figura 2.2 - Variável Dependente em um Modelo Contínuo.

Este trabalho dá ênfase à simulação discreta, devido à maior parte dos fenômenos de um sistema computacional ser tratada como discreta. O desenvolvimento de modelos é discutido em maiores detalhes na seção 2.3 .

A fase de formulação do modelo gera os requisitos para os dados de entrada. Em geral, os valores de entrada são inicialmente hipotéticos ou baseados em alguma análise preliminar. A sensibilidade dos resultados da simulação às mudanças nos dados de entrada pode ser avaliada pela realização de uma série de repetições da simulação, variando-se os dados de entrada.

Os dados de entrada são considerados fatores importantes em uma simulação. Esta pode obedecer a dois critérios de entradas de dados: Estocástico e Determinístico (Orlandi, 1995). 
Na Simulação Estocática (Probabilística ou Monte Carlo), os dados de entrada são gerados através das médias de distribuições probabilísticas e o modelo descreve o sistema em termos do tempo gasto em cada estado.

Na Simulação Determinística, os dados de entrada são descritos como uma seqüência de passos de trabalho, definida através de dados adquiridos a partir de um sistema existente.

A próxima etapa (tradução do modelo) de uma simulação consiste em traduzir o modelo para uma forma aceitável pelo computador. Um modelo para simulação pode ser programado através da utilização de várias ferramentas usuais de programação, tais como linguagens de programação de propósito geral, linguagens específicas de simulação, pacotes de simulação ou extensões funcionais de linguagens de programação convencionais (seção 2.4). A escolha da linguagem deve se basear no tipo de abordagem definida: evento, processo ou atividade (seção 2.3). Tal escolha também deve ponderar fatores como complexidade de desenvolvimento, restrições da linguagem, tempo de processamento, custo de execução, facilidade de programação, flexibilidade e portabilidade.

A etapa de verificação consiste em determinar se o modelo traduzido executa no computador como o esperado. Essa fase é responsável por verificar se o programa é ou não uma representação válida do modelo. Tal fato é normaimente realizado por uma checagem através de cálculos manuais. O processo de verificação também pode ser realizado através de métodos estatísticos (Soares, 1992).

O processo de validação consiste em determinar se o modelo é uma representação razoável do sistema real. O problema da validação pode ser dividido em dois grupos (MacDougall, 1987): validação de modelos de sistemas existentes e validação de modelos de projetos de sistemas. No primeiro caso, a validação pode ser feita através da comparação dos resultados fornecidos pelo programa de simulação com as medidas do sistema real. No segundo, a validação é realizada examinando-se o projeto do sistema. A validação pode se basear em comparações com outros modelos do sistema já validados, como por exemplo, modelos resolvidos analíticamente ${ }^{7}$ (Soares, 1992).

As etapas seguintes em um processo de simulação são a experimentação e a análise dos resultados, que envolvem a exercitação do modelo e uma cuidadosa interpretação das saídas.

\footnotetext{
${ }^{7} \mathrm{Um}$ modelo resolvido analiticamente descreve as operações de um sistema e a sua carga de trabalho em termos matemáticos; as soluções podem ser obtidas analítica ou numericamente. Normalmente os modelos resolvidos
} 
A última etapa consiste na documentação do modelo para simulação e da utilização do programa desenvolvido. Deve ficar claro que, embora o processo de desenvolvimento de uma simulação tenha sido descrito de maneira seqüencial, ele de fato não o é, pois permite interações entre os diversos passos do desenvolvimento da simulação.

O desenvolvimento de modelos e sua tradução para execução em um computador são duas fases de grande importância em um processo de simulação. Essas fases são discutidas nas seções 2.3 e 2.4 .

\subsection{Desenvolvimento de um Modelo para Simulação}

Um modelo de simulação descreve o comportamento dinâmico de um sistema, isto é, a maneira como este executa um determinado trabalho.

Pode-se dizer que um sistema é uma coleção de processos interativos, onde cada processo é composto por diversas atividades, com as suas interações controladas e coordenadas pela ocorrência de eventos (MacDougall, 1987). Os processos; as atividades e os eventos são representados como entidades ${ }^{8}$ no modelo a ser simulado.

O objetivo de um modelo para simulação é reproduzir o comportamento das entidades e, a partir daí, conhecer algo sobre o comportamento e desempenho do sistema. A relação entre essas entidades pode ser melhor entendida através da figura 2.3, e são definidas a seguir:

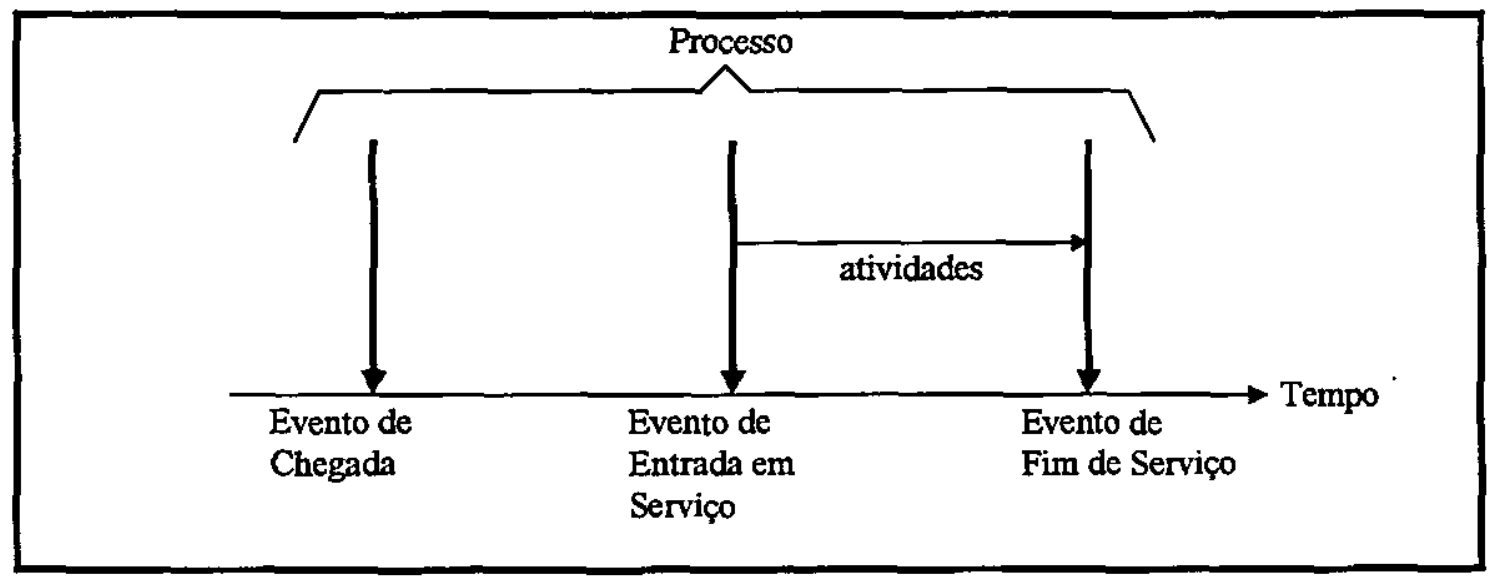

Figura 2.3 - Relações entre Evento, Processo e Atividade.

analiticamente, de sistemas computacionais, são representados através de redes de filas (Fernandes, 1992) (Soares, 1992).

${ }^{8}$ Entidades são objetos em um sistema. Existem diversos tipos de entidades, e cada uma possui vários tipos de caracteristicas ou atributos (Soares, 1992)(Tanir \& Sevinc, 1994). 
- Atividade: é uma unidade de trabalho e depende da visão particular do sistema. A íniciação e término de uma atividade são causados por eventos. Uma atividade pode ser, por exemplo, a execução de um passo de uma instrução ou uma tarefa completa, dependendo do nível de detalhamento considerado;

- Processo: é um conjunto de atividades logicamente relacionadas. O sistema em estudo é visto dinamicamente como uma coleção de processos que se interagem. Essa interação é controlada e coordenada pela ocorrência de eventos. A definição dos processos de uma simulação depende do nível de abstração adotado, por exemplo, um programa inteiro pode ser visto como um processo (compreendendo atividades de computação, leitura e escrita de dados). Em um outro nível, a execução de uma atividade de escrita pode ser vista como um processo compreendendo posicionamento, latência e transferência de dados. Uma operação definida como uma atividade em um nível de abstração pode ser definida como um processo compreendendo um conjunto de atividades em um outro nível de abstração;

- Evento: um evento corresponde a uma mudança ocorrida instantaneamente no estado de uma entidade do sistema, causada pela ação de uma atividade.

Um modelo para simulação discreta pode ser organizado segundo uma das três entidades básicas, abordadas anteriormente, resultando as seguintes orientações (Soares, 1992):

- Orientação a evento: definição das mudanças nos estados que podem ocorrer em cada tempo de evento.

- Orientação ao exame da atividade: descrição das atividades nas quais as entidades do sistema se envolvem;

- Orientação a processo: descrição dos processos através dos quais as entidades fluem; 
Esses conceitos levam naturalmente a três alternativas ou enfoques de modelagem para simulação discreta (Soares, 1992):

- Modelagem Orientada a Evento;

- Modelagem Orientada ao Exame da Atividade;

- Modelagem Orientada a Processo.

\subsubsection{Simulação Orientada a Evento}

Na simulação orientada a evento, um sistema é modelado através da definição das mudanças que ocorrem em cada evento. Cabe ao modelador determinar os eventos que podem causar a mudança no estado do sistema e desenvolver a lógica associada (algoritmo) a cada tipo de evento. $O$ sistema é simulado através da execução da lógica associada a cada evento, em uma seqüência ordenada no tempo.

Essa seqüência ordenada no tempo é mantida em uma lista de eventos futuros (estrutura de lista), na qual cada entrada contém o tempo de ocorrência de um evento juntamente com um identificador que define as ações a serem consideradas quando o evento ocorrer. $O$ identificador de evento correspondente é inserido na lista de eventos futuros por um mecanismo de escalonamento. Após completar todas as operações possiveis em um tempo de simulação particular, o mecanismo de escalonamento é ativado para selecionar o próximo evento a ser executado (MacDougall, 1975). Escalonar um evento significa gerar o tempo em que ocorrerá o próximo evento, inseri-lo na lista de eventos futuros, em forma ordenada pelo tempo de ocorrência.

Como exemplo, considere o atendimento a alunos por um professor na véspera de uma prova (Soares, 1992). Ao chegar na sala do professor, o aluno deve esperar em uma fila até que chegue a sua vez de ser atendido. Após terminarem suas dúvidas, o aluno deixa a sala do professor. As mudanças de estado no sistema ocorrem devido aos seguintes eventos:

- Um aluno chega para tirar suas dúvidas;

- Um aluno já foi atendido pelo professor e sai do sistema. 
A lógica associada aos eventos pode ser descrita da seguinte forma (Soares, 1992):

\section{Evento Chegada de Alunos}

Escalone a próxima chegada

Se o professor está ocupado

então Aumente o número de alunos na fila

senão Torne o estado do professor ocupado

Escalone o próximo fim de atendimento para

tempo_corrente + tempo_atendimento

Retorne (Fim do Procedimento)

\section{Evento Término de Atendimento}

Se existe algum aluno na fila

então Retire um aluno da fila para atendimento

Escalone o fim de atendimento para

tempo_corrente + tempo_atendimento

senão Torne o estado do professor desocupado

Retorne (Fim do Procedimento)

O programa de simulação pode ser organizado da seguinte forma:

Escalone a primeira chegada

Selecione o primeiro evento

Avance o tempo de simulação para o tempo de ocorrência do evento

Se final de simulação então

Imprima estatísticas

senão

Se evento $=$ Chegada de Aluno então

Trata Chegada de Aluno

Senão Trata término de atendimento 


\subsubsection{Simulação Orientada ao Exame da Atividade}

$\mathrm{Na}$ simulação orientada ao exame da atividade, o modelador descreve as atividades relacionadas com cada entidade do sistema, definindo as condições que causam o início e o fim de uma atividade. Os eventos. que iniciam ou terminam uma atividade não são escalonados pelo modelador, mas são iniciados a partir das condições especificadas para a atividade. À medida que o tempo simulado avança, as condições para o início ou o término de uma atividade são examinadas para assegurar que cada atividade é considerada.

Em certos tipos de problemas, o uso dessa abordagem fornece um modelo bem conciso. Esse modelo é particularmente adequado para situações onde a duração da atividade é indefinida e determinada pelo estado do sistema, satisfazendo a uma condição preestabelecida. Entretanto, devido à necessidade de se escalonar todas as atividades, a cada avanço do tempo, esse método é menos eficiente, quando comparado com a simulação orientada a evento (MacDougall, 1975)(Soares, 1992).

No exemplo do atendimento dos ahunos pelo professor, pode-se identificar uma única atividade:

- Atendimento.

A estrutura básica do programa de simulação é mostrada a seguir.

Início

tempo_de_simulação :=1

Se fim de simulação

então Imprimir estatísticas

senão Verificar o conjunto de atividades

Se chegada de aluno então Processa chegada

Se término de atendimento então Processa término tempo_de_simulação := tempo_de_simulação +1 


\subsubsection{Simulação Orientada a Processo}

Em simulação orientada a processo, o sistema a ser simulado é visto como uma coleção de processos interativos, controlados e coordenados pela ocorrência de eventos.

O programa de simulação é organizado como um conjunto de processos, os quais executam concorrentemente durante a simulação. A descrição de um processo tem a forma de um procedimento de uma linguagem de programação (MacDougall, 1975).

Analogamente à orientação a eventos, também existem um mecanismo de escalonamento e uma estrutura de lista, com a diferença que cada entrada na lista define um processo e seu ponto de reativaçāo (para processos que são bloqueados e novamente postos para executar).

Basicamente, uma simulação orientada a processo deve seguir os seguintes passos:

- Definir as entidades do sistema;

- Criar um processo para cada entidade descrevendo suas etapas;

- Executar concorrentemente os processos.

Dessa forma, pode-se considerar o exemplo dos alunos sendo atendidos pelo professor, descrito anteriormente, com o seguinte processo:

\section{Processo Aluno}

Se a fila estiver vazia e o professor estiver desocupado

então Torne o estado do professor ocupado

$\mathrm{O}$ aluno ocupa o professor pelo tempo de atendimento

Escalone o processo para tempo_corrente + tempo_atendimento

Torne o estado do professor desocupado

$O$ aluno parte do sistema

senão $O$ aluno entra na fila de espera 
O programa de simulação executa concorrentemente vários processos Aluno, que chegam segundo uma distribuição de probabilidade, requisitando serviços e indo embora.

Os modelos de simulação orientados a processos são implementados por linguagens especiais de programação que devem ter suporte à concorrência entre os processos, pois nesse contexto, um processo é um procedimento independente que pode ser executado concorrentemente com os demais. A simplicidade da simulação orientada a processos reside na facilidade de transposição dos processos que compõem o sistema real para a linguagem de programação (Soares, 1992), ou seja, esse tipo de abordagem possui capacidade descritiva e habilidade modular. Não possui, no entanto, a flexibilidade da simulação orientada a eventos, uma vez que fica restrito às linguagens que suportam o desenvolvimento do ambiente de concorrência entre processos.

O programa de simulação pode ser obtido através de um pacote de simulação, de uma linguagem de simulação existente ou de uma linguagem de propósito geral. Essas diversas linguagens e pacotes de simulação dão ao modelador a possibilidade de escrever programas de simulação orientada a evento, atividade ou processo.

\subsection{Implementação de um Modelo de Simulação}

Podem-se usar os seguintes enfoques para a implementação de um modelo de simulação:

- Linguagens de programação convencionais;

- Linguagens de simulação;

- Extensões funcionais;

- Pacotes de uso específico.

Um requisito importante de uma ferramenta para implementação de simulação é a presença de mecanismos para representação do tempo. Enquanto o sistema que está sendo modelado executa em tempo real, a simulação trabalha com um relógio próprio, que marca a passagem do tempo no programa de simulação. Outro requisito consiste em fornecer facilidades para coleta de estatísticas e emissão de relatórios (MacDougall, 1975). O grande problema da utilização de linguagem de 
programação convencionais à execução da simulação é a falta de requisitos, o que toma a implementação uma tarefa um tanto quanto árdua.

A crescente utilização da simulação tem ocasionado o surgimento de linguagens, extensões funcionais e pacotes que facilitam o exercício da simulação. As ferramentas disponíveis para a implementação de um modelo de simulação são descritas nas seções 2.4.1 a 2.4.4.

\subsubsection{Linguagens de Programação Convencionais}

Em princípio, toda linguagem de programação possui potencial para ser usada na implementação de uma simulação. No entanto, linguagens como Pascal, Modula 2, C, Fortran são projetadas para aplicações de propósitos gerais, não fornecendo todas as facilidades (estruturas de dados, processamento de listas e abstração de dados) necessárias para um ambiente de simulação. Procedimentos específicos são necessários para criar e manipular as interações dessas estruturas de programação (Saydam, 1985)(Pedgen, 1991).

Uma vantagem de se implementar um programa de simulação em uma linguagem convencional é que o programador não necessita aprender uma nova linguagem, pois pode trabalhar com a que está habituado. Entretanto, para criar um programa de simulação em uma linguagem de programação convencional, o programador deve criar todo o ambiente necessário para simulação. Isso pode ser considerado uma desvantagem, pois exige conhecimentos tanto na área de simulação quanto na de programação.

\subsubsection{Linguagens de Simulação}

As linguagens de simulação são projetadas para a modelagem de sistemas de vários tipos (Soares, 1992). Essas linguagens são classificadas em orientadas ao exame da atividade, a processos ou a eventos, baseadas na organização imposta pelo modelador (seção 2.3) (MacDougall, 1987)(Tanir \& Sevinc, 1994). As linguagens de simulação apresentam recursos que facilitam a implementação do programa de simulação, tais como: 


\subsubsection{Linguagens Orientadas a Evento}

Neste tipo de orientação, o programa de simulação é organizado como um conjunto de rotinas ou seções de eventos (MacDougall, 1975). A execução dos eventos é seqüencializada por uma lista de eventos futuros.

As linguagens orientadas a evento tendem a impor uma visão global e de alto nível do sistema ao modelador. Existe ainda a tendência de se englobar operações sobre atividades logicamente não relacionadas em um único evento. Em sistemas complexos, isso pode ocasionar a perda de identidade com a estrutura do sistema real, tornando os programas mais dificeis de serem alterados. Essa organização é melhor aplicada em sistemas de pequeno e médio portes (MacDougall, 1975).

Exemplos de linguagens orientadas a evento são: SIMSCRIPT, GASP e SLAM II.

\subsubsection{Linguagens Orientadas ao Exame da Atividade}

Nas linguagens orientadas ao exame da atividade, o programa de simulação é organizado através da descrição de todas atividades existentes em um sistema, identificando as condições que determinam o início e o fim de uma atividade. A cada avanço do tempo, todas as atividades devem ser examinadas. Para certos problemas, o uso dessa abordagem provê um modelo conciso, adequado para situações onde a duração da atividade é indefinida. Entretanto, essa organização não tem sido largamente adotada, devido à sobrecarga gerada para examinar todas as atividades a cada ciclo de relógio. Um exemplo de linguagem de simulação orientada ao exame da atividade é CSL (MacDougall, 1975).

\subsubsection{Linguảgens Orientadas à Processsó}

As linguagens orientadas a processo apresentam a vantagem de permitir uma representação mais natural do modelo (MacDougall, 1987). Essa característica é importante em sistemas de grande porte, onde o programa de simulação tende a se tornar uma descrição do comportamento do sistema real, estabelecendo assim maior identidade com o mesmo. 
Alguns exemplos de linguagens de simulação orientada a processo são: GPSS, Q-GERT (Soares, 1992), ASPOL (Soares, 1992)(MacDougall, 1987), SIMULA (MacDougall, 1975)(Saydam, 1985), SOL (MacDougall, 1975), SIMPLI X (Saydam, 1985) e RESQ (Soares, 1992).

\subsubsection{Extensões Funcionais}

Extensões funcionais são bibliotecas que, juntamente com uma linguagem hospedeira (como Modula 2 ou C), compõem um ambiente completo de simulação. As extensões funcionais apresentam as vantagens de uma linguagem convencional (o programador escolhe a linguagem que está familiarizado) e as ferramentas especificas de uma linguagem de simulação.

Alguns exemplos de extensões funcionais são:

- SimPack (Cubert \& Fiswick, 1995) (orientada a evento), SMPL (MacDougall, 1987) (orientada a evento), CSIM (Edwards \& Sankar, 1992) (orientada a processo) e EFC (Souza, 1991) (orientada a processo): são extensões da linguagem $\mathbf{C}$.

- EFM2 (Spolon, 1992) e HPSIM (Sharma \& Lauwrence, 1988) (orientadas a processo): são extensões da linguagem Modula 2.

\subsubsection{Pacotes de Simulação de Uso Específico}

Os pacotes de uso especifico são voltados para a avaliação de sistemas particulares. Nesses pacotes, a formulação do modelo é construída na própria ferramenta, sendo os parâmetros do modelo especificados através de uma linguagem relacionada com o sistema modelado. Quando o sistema se adapta à linguagem de modelagem, é fácil construir o modelo e analisar o sistema. Entretanto, devido ao fato de serem muito específicos para uma dada aplicação, esses pacotes oferecem pouca flexibilidade a mudanças. Alguns exemplos são (Soares, 1992): 
- BEST/1, CMF, FIVE, XL, PERFORMS, VM Predictor: para modelagem de sistemas computacionais e seus respectivos sistemas operacionais.

- PET, NETWORK 1 .5: para modelagem de redes de computadores.

- MAP/1, MAST: para modelagem de operações sistemas de manufatura.

- IDSS 2.0: para modelagem de sistemas aeroespaciais.

- SNAP: para modelagem de segurança de reatores nucleares.

- CROPS: para modelagem de sistemas agrícolas.

\subsection{Considerações Finais}

Simulação é uma técnica que tenta imitar o comportamento de um sistema em estudo. É uma técnica que tem sido amplamente utilizada em diversas áreas do conhecimento humano. Em particular, na área de sistemas computacionais, ela vem sendo empregada para avaliação de desempenho (MacDougall, 1987)(Soares, 1992)(Pedgen, 1991).

O sistema a ser simulado pode utilizar uma abordagem discreta ou contínua. Por mais que a simulação contínua venha sendo largamente utilizada em diversas áreas, o estudo de sistemas computacionais é geralmente desenvolvido através de modelos discretos. A simulação discreta pode ser organizada seguindo orientações a evento, a processo ou ao exame da atividade.

A orientação a evento fornece maior facilidade na implementação de programas de simulação de sistemas de pequeno e médio portes. Essa orientação não oferece um relacionamento claro entre o sistema a ser simulado e os procedimentos do programa de simulação. Os programas de simulação que seguem a orientação a processo são considerados mais complexos, pois podem ativar diferentes processos concorrentemente. No entanto, o relacionamento entre o programa e o sistema real é bastante claro, o que o torna hábil para implementação de programas de simulação de grandes sistemas. A orientação ao exame da atividade é muito pouco utilizada, sendo desconsiderada por alguns autores.

O uso generalizado da simulação como uma metodologia de análise de sistemas originou uma série de linguagens especificamente utilizada para este fim. Essas linguagens e pacotes de modelagem impõem uma certa estruturação nos modelos e simplificam suas soluções. A utilização de pacotes apresentam a vantagem de oferecer ferramentas específicas para simulação. 
Toda linguagem de programação pode ser usada na implementação de um sistema de simulação. A grande vantagem dessas linguagens está no fato do programador não necessitar aprender uma nova linguagem, podendo trabalhar com a que está habituado. A desvantagem está na ausência de um suporte orientado a simulação, determinando que o usuário programe todo o ambiente de simulação.

As extensões funcionais são bibliotecas que são inseridas em uma linguagem de programação de propósito geral (linguagem hospedeira). Isso permite a exploração dos recursos da linguagem hospedeira juntamente com uma maior facilidade na escrita do programa de simulação. 


\section{Capítulo 3}

\section{Computação Paralela}

Este capitulo apresenta uma visão geral da computação paralela, através da abordagem de seus tópicos mais relevantes. Apresenta-se basicamente dividido nas seguintes seções: conceitos básicos, arquiteturas paralelas e programação concorrente.

\subsection{Introdução}

Segundo Hwang (Hwang \& Briggs, 1984), a definição de computação paralela (ou processamento paralelo) apresenta-se como:

"Forma eficiente do processamento de informações com ênfase na exploração de eventos concorrentes no processo computacional".

Processamento paralelo consiste na divisão de uma determinada aplicação, de forma que esta possa ser executada por vários elementos de processamento, que deverão cooperar entre si (comunicação e sincronismo), visando melhorar sua eficiência através da quebra do paradigma de execução seqüencial do fluxo de instruções, ditado pela filosofia de von Neumann.

A idéia de processamento paralelo não é nova. O próprio von Neumann em seus artigos, por volta de 1940, sugeriu formas paralelas de se resolver equações diferenciais. Porém, o surgimento do computador ILLIAC IV, construído na Universidade de Illinois em 1971 (composto por 64 processadores), foi considerado o marco inicial do processamento paralelo (Amorim, 1988) (Navaux, 1989).

Vários fatores explicam a necessidade do processamento paralelo. O principal deles trata da busca de maior desempenho. Os outros fatores que motivam o desenvolvimento da computação paralela são (Almasi \& Gottlieb, 1994)(Zaluska, 1991)(Amorim, 1988):

- O desenvolvimento tecnológico (sobretudo após o surgimento da tecnologia VLSI), permitiu a construção de microprocessadores de alto desempenho, que agrupados, 
possibilitam um ganho significativo de poder computacional. Além disso, tais configurações possibilitam uma melhor relação custo/desempenho quando comparadas aos supercomputadores de custo extremamente alto (Zaluska, 1991);

- Restrições físicas, como a velocidade finita da luz, tornam dificil o aumento de velocidade em um único processador;

- A configuração modular de vários processadores permite o agrupamento desses processadores em módulos, de acordo com a natureza de aplicação. Além disso, pode-se expandir o sistema através da inclusão de novos módulos;

- Tolerância a falhas ocasionada pela redundância de hardware.

- O chamado "gargalo de von Neumann" tem diminuído a produtividade do programador, pois muitos problemas apesar se serem intrinsecamente paralelos, são solucionados de maneira seqüencial, diminuindo dessa forma a produtividade do programador, uma vez que são necessárias novas formas de organização do processamento computacional.

\subsection{Conceitos Básicos}

Esta seção apresenta alguns dos principais conceitos relacionados à computação paralela. São descritos os seguintes tópicos: tipos de paralelismo, pipeline, granulosidade, speedup e eficiência.

\subsubsection{Tipos de Paralelismo}

Processar eventos computacionais concorrentemente indica que, em um determinado instante, dois ou mais eventos foram iniciados e ainda não terminados. Com essa definição, podem-se abstrair dois tipos de paralelismo: paralelismo lógico e físico (Kirner, 1991).

- Paralelismo Lógico (Concorrência). Neste caso, tem-se apenas um elemento de processamento, e os eventos são executados intercaladamente, de maneira que apenas um está ativo a cada instante. Concorrência implica em mais de um processo iniciado e ainda não terminado. Não é necessário haver mais de um elemento de processamento. Esse tipo de paralelismo é mostrado na figura 3.1. 


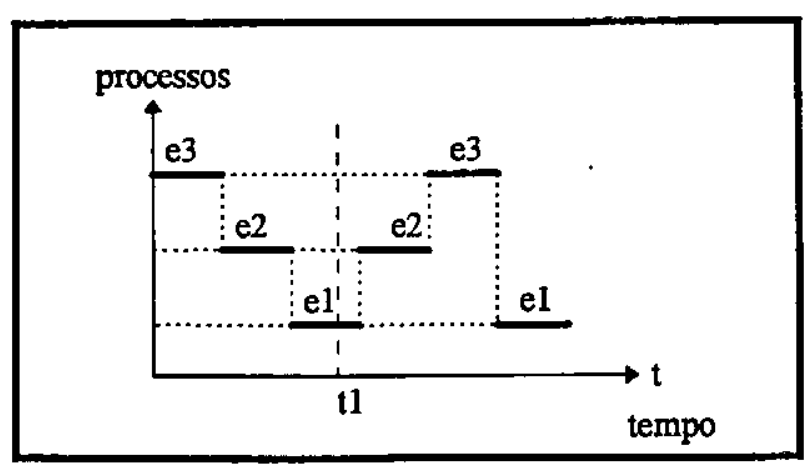

Figura 3.1 - Paralelismo Lógico

- Paralelismo Físico. Na literatura, o termo paralelismo é normalmente utilizado para designar paralelismo físico. Paralelismo é um caso especial de concorrência, onde existem processos sendo executados ao mesmo tempo. Isto é, tem-se um elemento de processamento para cada evento que está sendo executado, sendo que todos os eventos podem estar ativos simultaneamente, como mostrado na figura 3.2 .

Se existem $n$ elementos de processamento e $m$ eventos sendo executados concorrentemente, onde $n<m$, tem-se uma situação de paralelismo misto, podendo-se encontrar simultaneamente paralelismo lógico e físico.

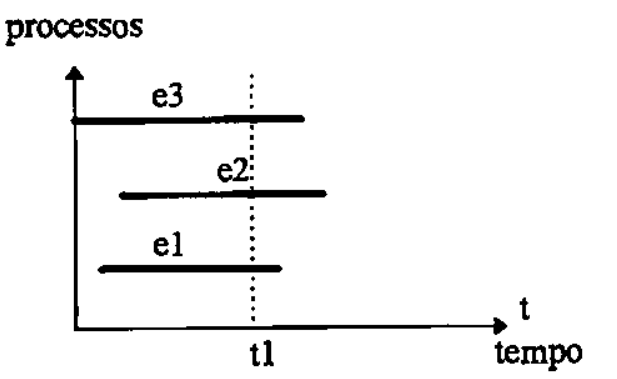

Figura 3.2 - Paralelismo Físico

\subsubsection{Granulosidade}

A granulosidade (ou nivel de paralelismo) representa o tamanho das tarefas submetidas aos processadores (Almasi \& Gottlieb, 1994) e pode ser classificada em fina, média e grossa (Almasi \& Gottlieb, 1994)(Hwang \& Briggs, 1984). 
A granulosidade fina indica que o paralelismo está sendo realizado em nível de operações ou instruções. Geralmente, esse tipo de granulosidade requer um número maior de processadores mais simples.

A granulosidade média indica o paralelismo obtido através da execução de trechos ou subrotinas do programa.

A granulosidade grossa relaciona o paralelismo em nível de processos. Geralmente, esse tipo de granulosidade requer um número menor de processadores, podendo estes serem mais genéricos e complexos.

\subsubsection{Speedup e Eficiência}

Um dos fatores principais da computação paralela é o aumento de velocidade de processamento obtido com o uso do paralelismo. Para verificar o aumento obtido, duas medidas são utilizadas na literatura (Almasi \& Gottlieb, 1994)(Kirner, 1991): speedup e eficiência.

Speedup (Sp) é utilizado para determinar o aumento de velocidade obtido durante a execução de um programa em $p$ processadores, em relação à execução desse mesmo programa em um único processador.

$$
\mathbf{S p}=\mathbf{T}_{1} / \mathbf{T}_{\mathbf{p}}
$$

Onde $\mathbf{T}_{1}$ é o tempo de execução em um processador e $\mathbf{T}_{\mathbf{p}}$ é o tempo de execução em $p$ processadores.

$\mathrm{O}$ caso ideal é quando $\mathrm{Sp}=\mathbf{p}$, isto é, o ganho de speedup tende a $p$, indicando que a velocidade de processamento é diretamente proporciōnäl ao número de processadōres. Porém, existem três fatores que dificultam a obtenção do caso ideal: sobrecarga da comunicação entre processadores, partes do código executável estritamente seqüenciais (que não podem ser paralelizadas) e o nível de paralelismo utilizado (devido à granulosidade ser inadequada ao tipo de arquitetura utilizada). 
Outra medida importante é a eficiência (Ep), que trata da relação entre o speedup e o número de processadores.

$$
\mathbf{E p}=\mathrm{Sp} / \mathbf{p}
$$

A eficiência fornece o "quanto" os processadores estão sendo utilizados. Varia entre 0 e l, seu caso ideal é obtido quando $\mathbf{E}_{\mathbf{p}}=\mathbf{1}$, indicando uma eficiência de $100 \%$.

\subsection{Arquiteturas Paralelas}

Diversas arquiteturas surgiram com o avanço da computação paralela. Devido às diferenças encontradas em nível de hardware e propósitos, tornou-se necessária uma organização coerente e concisa dessas arquiteturas. Várias classificações são propostas na literatura (Almasi \& Gottlieb, 1994)(Navaux, 1989) (Tanenbaum, 1998), as mais conhecidas são: a classificação de Flynn (Flynn, 1972) e a classificação de Duncan (Duncan, 1990).

A classificação de Flynn, apesar de antiga, é ainda bastante utilizada. A classificação de Duncan apresenta o esforço de acomodar novas arquiteturas que surgiram após a taxonomia de Flynn.

\subsubsection{Classificação de Flynn}

Segundo Flynn (Flynn, 1972), o processo computacional pode ser visto como um fluxo de instruções executando sobre um fluxo de dados (Hwang \& Briggs, 1984)(Navaux, 1989)(Almasi \& Gottlieb, 1994)(Duncan, 1990).

A classificação de Flynn acomoda as arquiteturas em quatro classes de máquinas: SISD, SIMD, MISD e MIMD. 
FI = Fluxo de Instruções

UC = Unidade de Controle

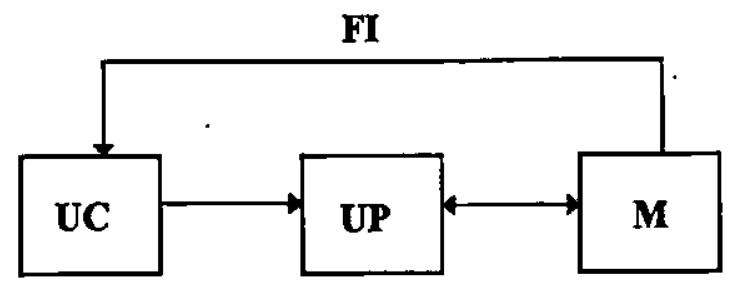

UP = Unidade de Processamento

$\mathbf{M}=$ Memória

Figura 3.3 - Exemplo de Arquitetura SISD.

SISD - Single Instruction Stream / Single Data Stream (Fluxo único de instruções / Fluxo único de dados): corresponde ao tradicional modelo de von Neumann. Um processador executa seqüencialmente um conjunto de instruções sobre um conjunto de dados (figura 3.3). Essa classe representa a maioria dos computadores atualmente disponivel.

SIMD - Single Instruction Stream / Multiple Data Stream (Fluxo único de instruções / Fluxo múltiplo de dados): envolve múltiplos processadores executando simultaneamente a mesma instrução em diversos conjuntos de dados (figura 3.4). Exemplos dessa classe são as máquinas paralelas com processadores vetoriais e matriciais (Kirner, 1991).

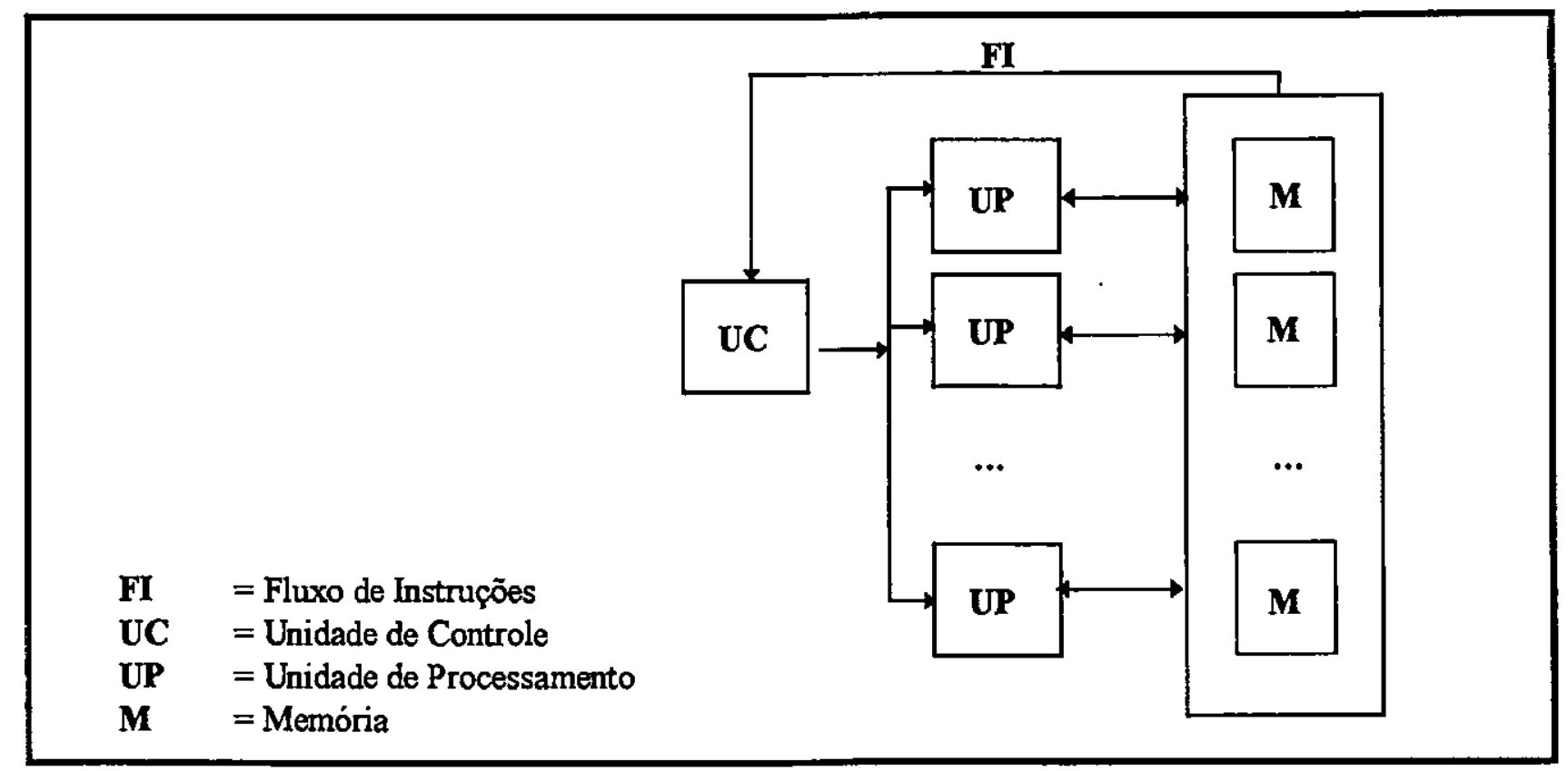

Figura 3.4 - Exemplo de Arquitetura SIMD. 
MISD - Multiple Instruction Stream / Single Data Stream (Fluxo múltiplo de instruções / Fluxo único de dados): envolve múltiplos processadores executando diferentes instruções em um único conjunto de dados (figura 3.5). Geralmente, nenhuma arquitetura é classificada como MISD. Alguns autores (Almasi \& Gottlieb, 1994)(Navaux, 1989) consideram o pipeline 9 como um representante dessa categoria.

MIMD - Multiple Instruction Stream / Multiple Data Stream (Fluxo múltiplo de instruções / Fluxo múltiplo de dados): envolve múltiplos processadores executando diferentes instruções em diferentes conjunto de dados, com a interação entre os processadores feita pela memória (memória compartilhada) ou através de troca de mensagens (memória distribuida), conforme apresentado na figura 3.6.

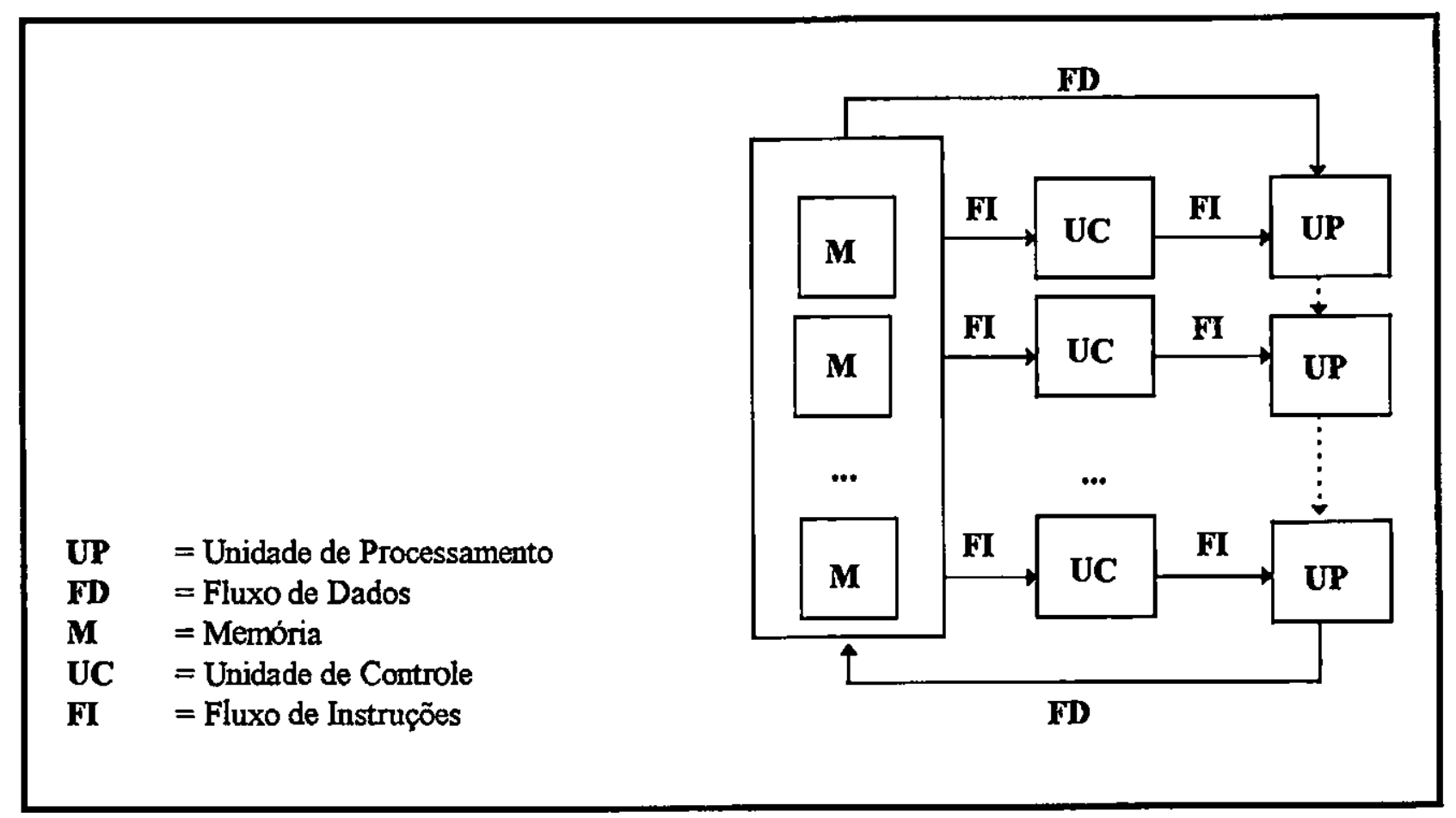

Figura 3.5 - Exemplo de Arquitetura MISD.

\footnotetext{
${ }^{9}$ Pipeline implementa um paralelismo temporal, caracterizado quando existe a execução de eventos sobrepostos no tempo. A tarefa que será executada é dividida em sub-tarefas, cada uma destas sendo executada por um estágio de hardware especializado que trabalha de maneira concorrente com os demais estágios envolvidos na computação.
} 
UP = Unidade de Processamento

FD = Fluxo de Dados

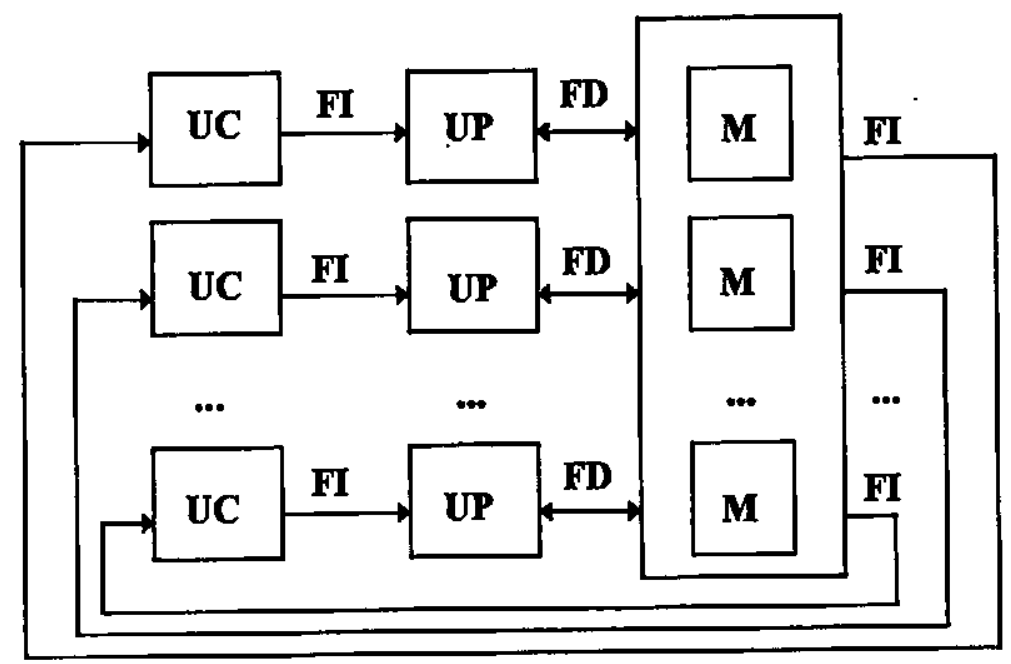

$\mathbf{M}=$ Memória

UC = Unidade de Controle

FI = Fluxo de Instruções

Figura 3.6 - Exemplo de Arquitetura MIMD.

\subsubsection{Classificação de Duncan}

Duncan (Duncan, 1990) estabeleceu uma nova taxonomia visando acomodar as inovações arquiteturais surgidas após a classificação de Flynn. Nessa classificação, Duncan considerou os seguintes aspectos básicos:

- manter os elementos de classificação de Flynn, devido à sua ampla utilização;

- excluir arquiteturas que apresentam mecanismos de paralelismo de baixo nível, como exemplos, podem-se citar o pipeline dos estágios de execução de uma instrução e unidades funcionais múltiplas em uma única CPU.

A classificação de Duncan é apresentada na figura 3.7. 


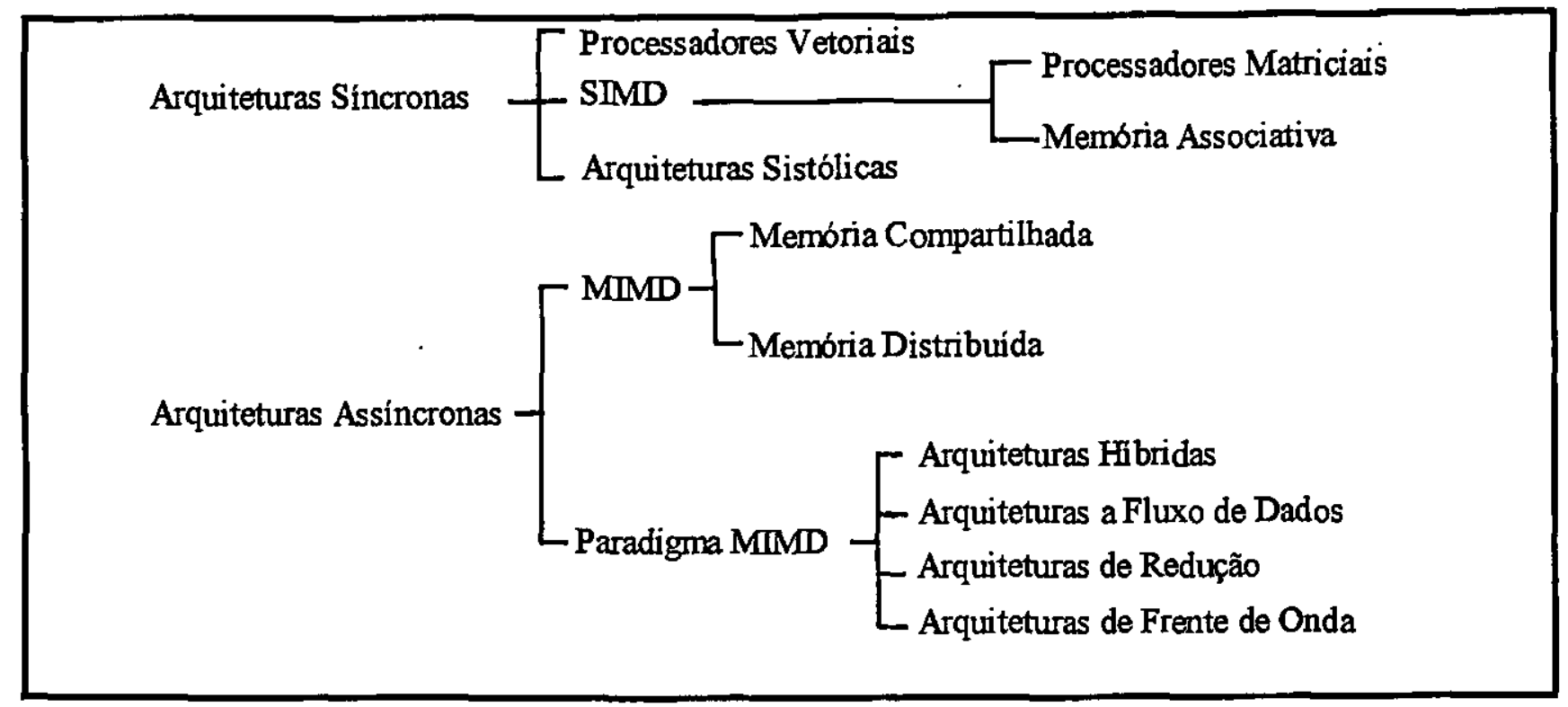

Figura 3.7 - Classificação de Duncan.

Arquiteturas Síncronas. Nessas arquiteturas, as operações concorrentes são coordenadas através de relógios globais, unidades de controle únicas ou controladores de unidades vetoriais (Duncan, 1990).

Processadores Vetoriais: caracterizam-se por possuírem um hardware específico (múltiplas unidades funcionais organizadas de maneira pipeline) para a otimização de operações em vetores. Essas arquiteturas fornecem mecanismos eficientes para cálculos pesados em matrizes ou vetores (Souza, 1997a).

Arquiteturas SIMD: essas arquiteturas apresentam uma unidade central de controle, vários processadores e uma rede de interconexão, que estabelece a comunicação entre processadores e/ou entre processadores e a memória. Nessas arquiteturas, um único fluxo de instruções atua sobre diferentes dados.

Arquiteturas Sistólicas: essas arquiteturas possuem vários processadores organizados em pipeline. Apenas os processadores localizados nos limites da estrutura possuem comunicação com a memória. Os dados percorrem todos os processadores, de forma rítmica e sincronizada por um relógio global, sem armazenamento temporário na memória. Essas arquiteturas são empregadas em aplicações específicas que possuem granulosidade fina. 
Arquiteturas Assíncronas. Caracterizam-se pelo controle descentralizado de hardware, onde cada elemento de processamento executa diferentes instruções sobre diferentes dados.

Arquiteturas MIMD: essas arquiteturas possuem vários processadores que operam de forma independente. Esse tipo de organização possibilita um alto nível de paralelismo (granulosidades média e grossa). A comunicação e o sincronismo são realizados de acordo com a organização da memória, que pode ser centralizada ou distribuída (figura 3.8).

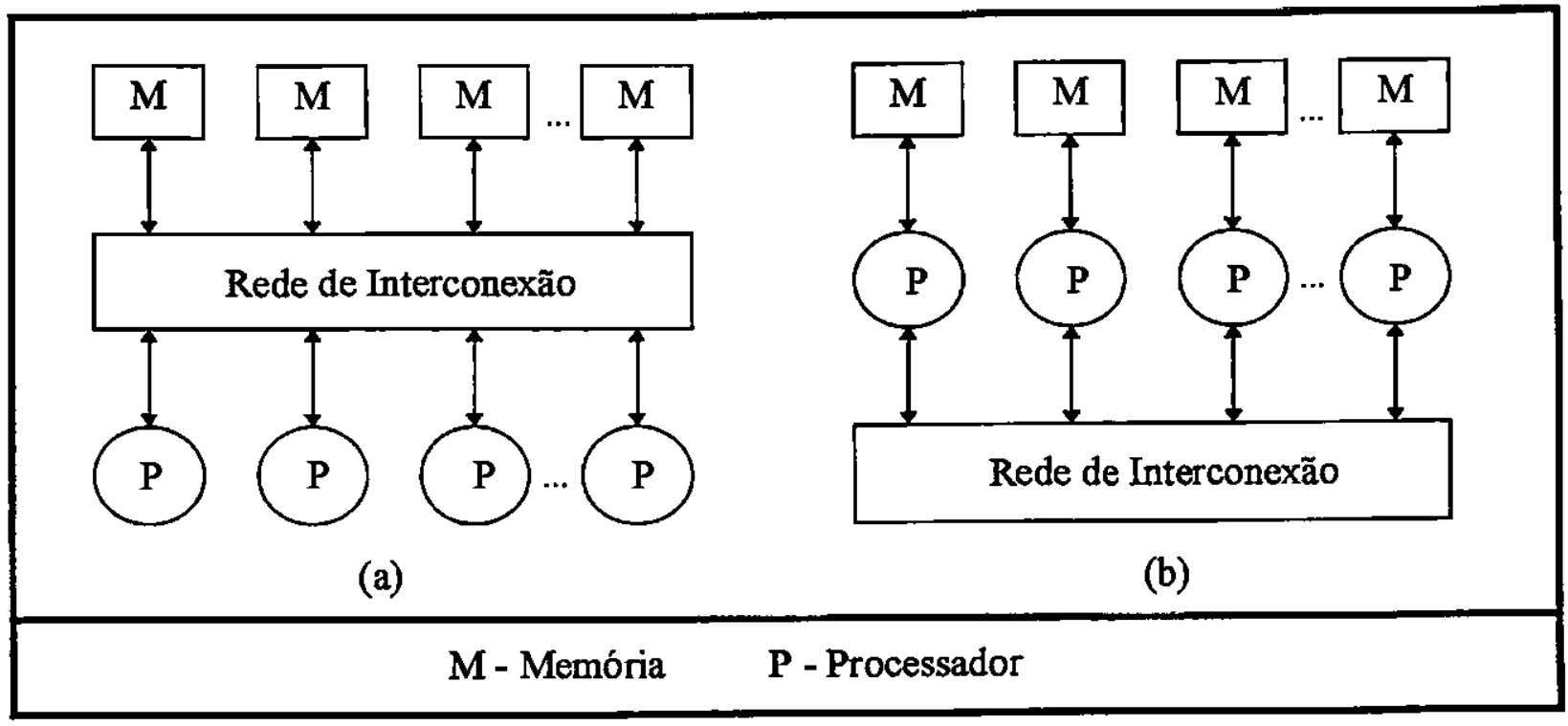

Figura 3.8 - Arquiteturas MIMD. (a) Memória Compartilhada (b) Memória Distribuída

Nas arquiteturas MIMD com memória centralizada, todos os processadores são ligados a uma única memória global (figura 3.8 (a)). Esse tipo de organização também é chamada de multiprocessador. A comunicação e o sincronismo entre processos ocorrem através do compartilhamento de dados na memória. Entretanto, isso não impede que seja utilizado o paradigma de troca de mensagens (Almasi \& Gottlieb, 1994)(Tanenbaum, 1995).

As arquiteturas MIMD com memória distribuída, também conhecidas como multicomputadores, caracterizam-se por não possuírem memórias compartilhadas entre os elementos de processamentos (figura 3.8 (b)). Nessa organização, cada processador possui memória local. A comunicação e o sincronismo entre os processos são feitos através do paradigma de troca de mensagens (Almasi \& Gottlieb, 1994)(Tanenbaum, 1995). 
Paradigma MIMD: essa classe engloba as arquiteturas assíncronas que, apesar de possuírem características de multiplicidade de fluxo de dados e instruções, também possuem características próprias que dificultam sua classificação como puramente MMD. Nessa classe encontram-se as máquinas híbridas (MIMD/SIMD) (Duncan, 1990), arquiteturas a fluxo de dados (dataflow) (Hwang \& Briggs, 1984), arquiteturas de redução (Kirner, 1991) e arquiteturas de frente de onda.

\subsection{Programação Concorrente}

Um programa seqüencial é composto por um conjunto de instruções que são executadas seqüencialmente. A execução dessas instruções é denominada processo. Um programa concorrente é formado por dois ou mais programas seqüenciais que podem ser executados concorrentemente como processos paralelos (Andrews \& Schneider, 1983).

Um programa seqüencial é constituído basicamente de um conjunto de construções bem conhecido pelo programador que utiliza linguagens de alto nível como $C$, Fortran e Pascal. Exemplos de construções são: comando de decisão (if... then... else), laços (for... do), etc.. A programação concorrente necessita de recursos não disponíveis diretamente nas linguagens de alto nível. Essa necessidade é gerada através da inclusão de novas fontes de complexidade à programação seqüencial. São necessários métodos para definir quais tarefas serão executadas em paralelo, métodos para a ativação e finalização da execução dessas tarefas, bem como os meios para coordenar a interação entre elas.

O objetivo da programação concorrente é suprir essas necessidades, fornecendo ferramentas para a construção de programas paralelos que utilizam o hardware disponivel, seja este paralelo ou não (Almasi \& Gottlieb, 1994)(Foster, 1995).

Segundo Almasi (Āìmasi \& Gottlieb, 1994), três fatores são necessários para a execução đe um programa paralelo:

- Definir um conjunto de tarefas a serem executadas em paralelo;

- Iniciar e finalizar a execução dessas tarefas;

- Coordenar e especificar a interação entre as tarefas, enquanto elas estiverem em execução. 
O desenvolvimento de um eficiente algoritmo paralelo é de extrema importância, pois o ganho de desempenho adquirido com a paralelização depende diretamente da forma de como as tarefas serão executadas concorrentemente.

Depois de definir como as tarefas serão organizadas, faz-se necessário o uso de ferramentas, que possibilitam ao programador representar a concorrência, definindo quais partes do código serão paralelizadas e quais serão seqüenciais. As notações que definem, ativam e finalizam a execução de processos paralelos são abordadas na seção 3.5.1. Além disso, torna-se necessário o uso de mecanismos para coordenar a execução dos processos. Esses mecanismos, que determinam a comunicação e sincronismo entre processos, são discutidos na seção 3.5.2.

\subsubsection{Declaração de Processos Concorrentes}

Várias notações para a ativação e término de processos concorrentes são discutidas na literatura (Almasi \& Gottlieb, 1994)(Andrews \& Schneider, 1983)(Quinn, 1987). As principais são apresentadas a seguir:

FORK/JOIN. O comando FORK inicia a execução de um processo (processo filho), concorrentemente com outros processos que estão sendo executados (processo pai - quem executou o FORK - e demais processos em execução). O comando JOIN realiza a sincronização dos processos ativos (figura 3.9). As sintaxes dos comandos FORK/JOIN são:

FORK endereco - executa o processo especificado em endereço concorrentemente com os demais processos.

JOIN var, end1 $\underline{\text { end2 }}$ - decrementa yar em uma unidade e depois verifica seu conteúdo. Se este for igual a 0 (zero), desvia a execução para end1. Caso contrário, desvia para end2.

A principal vantagem dos comandos FORK/JOIN é a flexibilidade. O que permite a representação de qualquer execução concorrente. No entanto, é pouco estruturado, o que dificulta 0 entendimento do código.

COBEGIN/COEND. Essas declarações utilizam formas bem estruturadas para ativar processos concorrentes. Todos os comandos que se encontram entre o COBEGIN e o COEND são executados em paralelo (figura 3.10). Essa estrutura é menos flexível, pois todos os processos ativados em paralelo devem ser finalizados para tornar possível a execução de outros processos. 

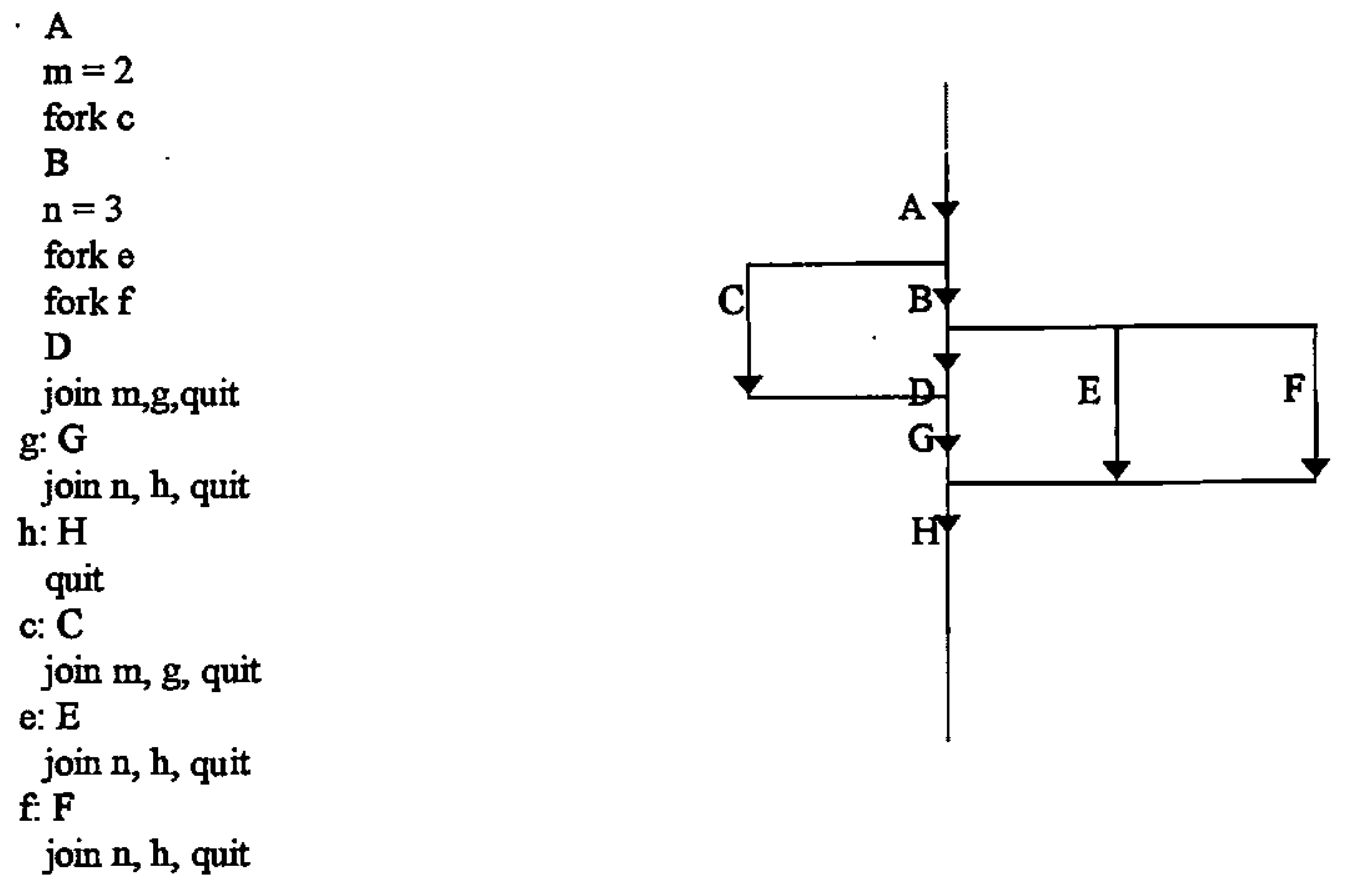

Figura 3.9 - Exemplo da Utilização dos comandos FORK/JOIN.

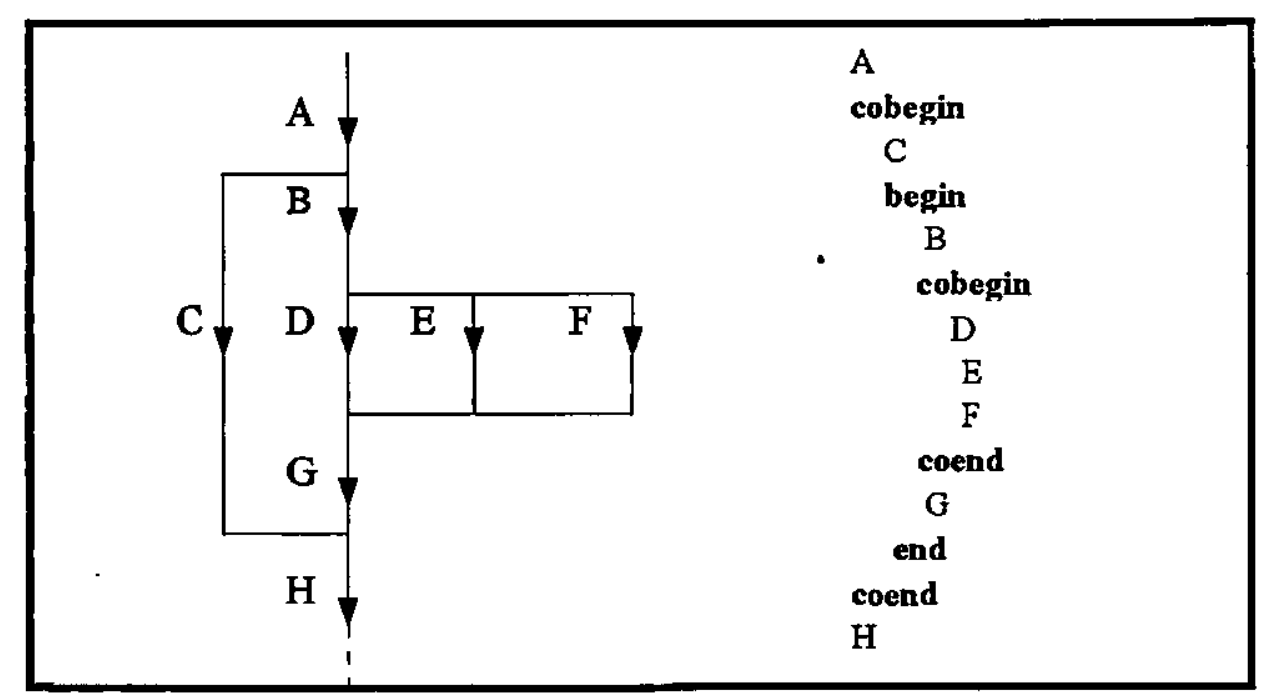

Figura 3.10 - Exemplo da Utilização dos Comandos COBEGIN/COEND.

Corotinas. Corotinas são subrotinas que possuem um modo de transferência de controle não hierárquico. Uma subrotina comum é ativada através de uma chamada call subrotina. O controle retorna ao módulo de programa que a ativou e termina sua execução através do comando return (Souza, 1997a). 
Corotinas transferem controle entre si de maneira livre, através do comando resume corotina (Almasi \& Gottlieb, 1994). Sempre que uma corotina é ativada, ela inicia sua execução a partir do ponto onde foi executada a última chamada resume (figura 3.11). Uma corotina pode ser vista como um processo. Apenas uma corotina está ativa em cada instante de tempo, tornando o modelo de corotinas similar ao sistema que possui um único elemento de processamento compartilhado por vários processos concorrentes.

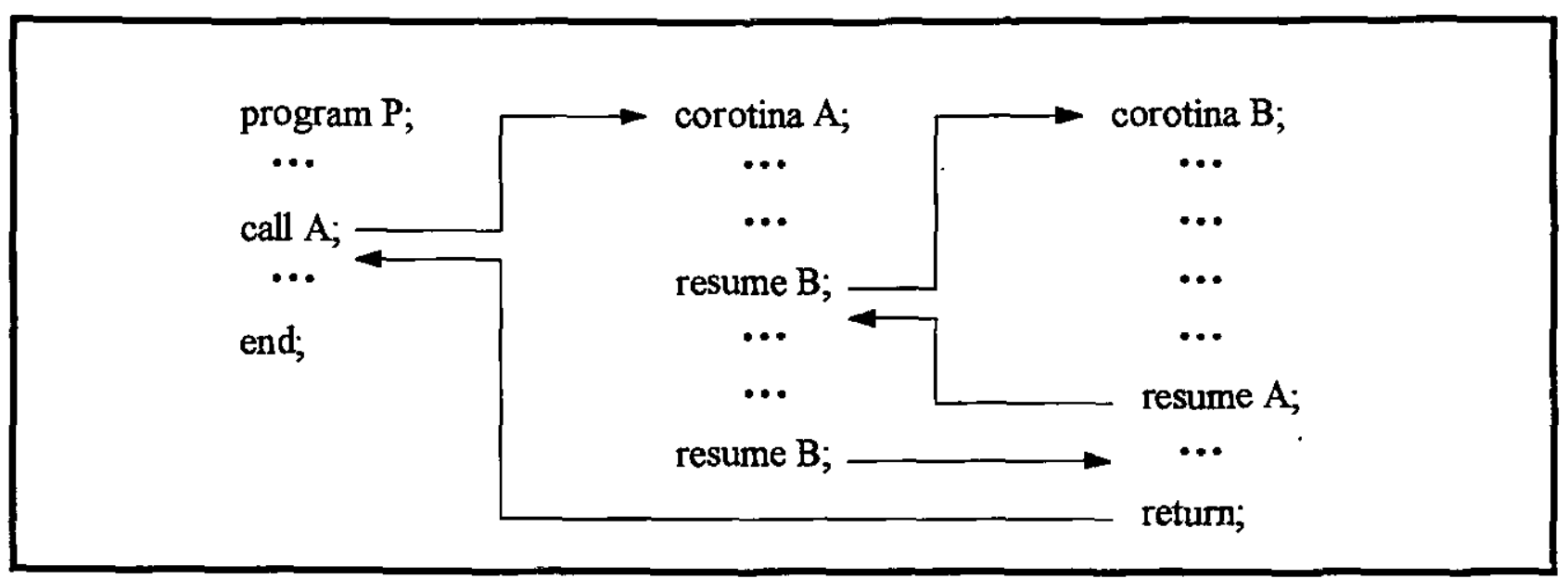

Figura 3.11 - Exemplo de Utilização de Corotinas.

DOALL. Similar aos comando COBEGIN/COEND, esse comando executa instruções em paralelo que formam as diversas instância de um bloco de comandos dentro de um comando de loop (figura 3.12). 


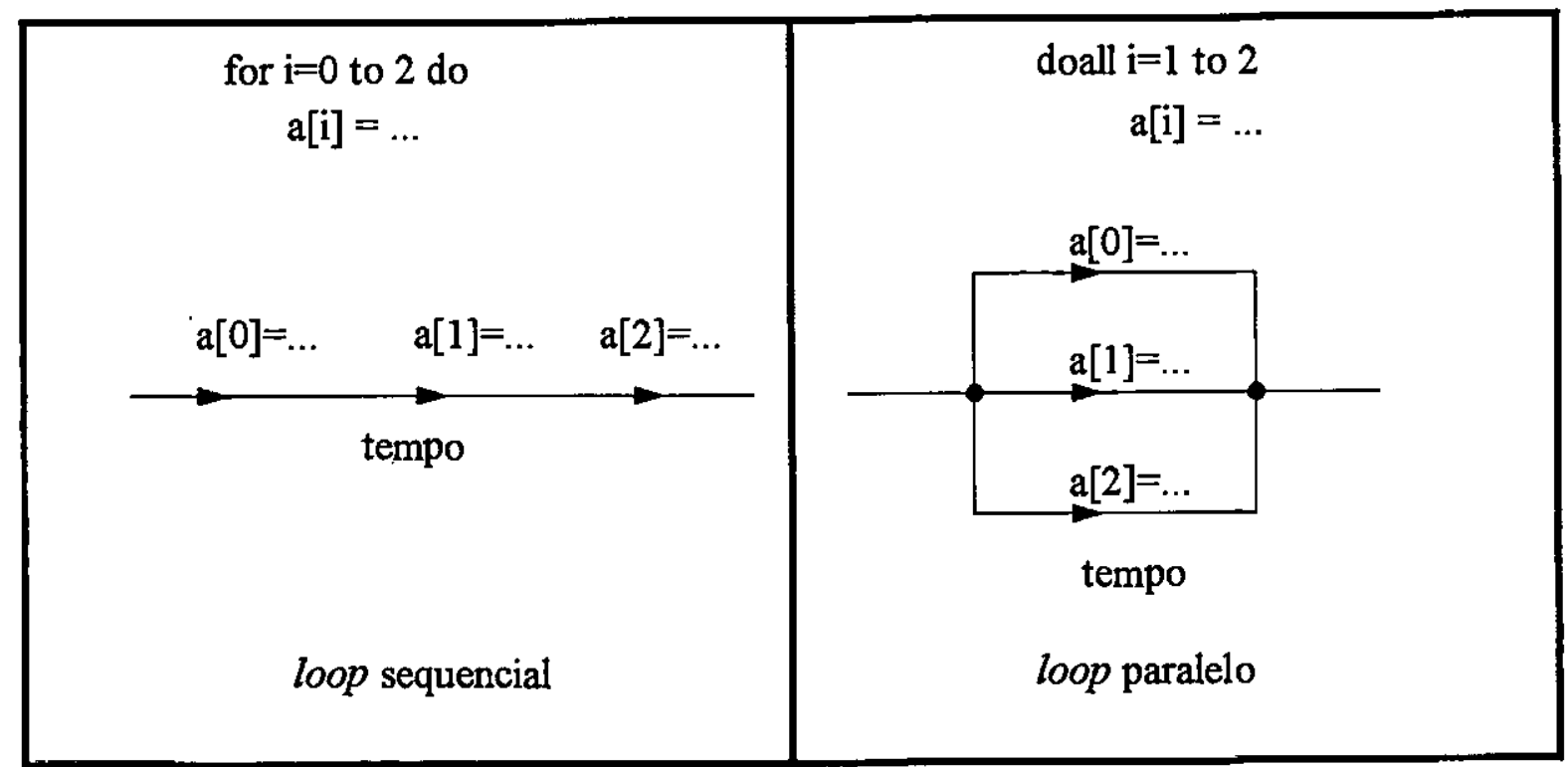

Figura 3.12 - Exemplo da Utilização do $D O A L L$.

\subsubsection{Comunicação e Sincronismo}

A comunicação permite que os processos troquem informações quando executam determinadas tarefas. A sincronização é muito importante dentro da comunicação de processos paralelos, pois ela realiza o controle de seqüência e o controle de acesso durante a execução de processos concorrentes. $O$ controle de seqüência é utilizado para determinar a ordem em que os processos serão executados. O controle de acesso é utilizado para determinar quem utilizará os recursos do sistema compartilihados pelos processos concorrentes (Almasi \& Gottlieb, 1994).

Os processos podem se comunicar através do uso de variáveis compartilhadas ou através de àmbientes de passagem de mensagens. Sendo que a comunicą̧ão através de variáveis compartilhadas utiliza arquiteturas com memória centralizada, e a comunicação através de troca de mensagens utiliza arquiteturas com memória distribuída.

Comunicacão e Sincronismo em Memória Centralizada. A comunicação e sincronismo em memória centralizada são implementados através do uso de variáveis compartilhadas entre vários processos concorrentes. $O$ controle de acesso é geralmente implementado através da exclusão mútua. Os mecanismos busy-waiting, Semáforo e Monitor são os mais utilizados para o controle de acesso e controle de sequiência em memória centralizada (Almasi \& Gottlieb, 1994)(Andrews \& Schneider, 1983)(Tanenbaum, 1998). 
Comunicacão e Sincronizaç̃o em Memória Distribuída. Comunicação e sincronismo em memória distribuída são implementados através do mecanismo de troca de mensagens (Almasi \& Gottlieb, 1994)(Andrews \& Schneider, 1983)(Kirner, 1989). Uma operação de troca de mensagens é realizada, geralmente, através do uso das primitivas send/receive. As sintaxes dessas primitivas, por exemplo, podem ser:

Send mensagem to processo_destino

Receive mensagem from processo_fonte

Uma transferência de mensagem pode ser realizada de dois modos: através de uma operação bloqueante (síncrona - figura 3.13 (a)), onde o processo transmissor é bloqueado até receber uma confirmação de recebimento da mensagem pelo processo receptor, ou através de uma operação não bloqueante (assíncrona - figura 3.13 (b)), onde a mensagem enviada pelo processo é armazenada em um buffer, permitindo a execução normal do processo transmissor.

As primitivas send/receive podem gerar três mecanismos básicos para executar trocas de mensagens: Comunicação ponto a ponto, Rendezvous e RPC (Almasi \& Gottlieb, 1994) (Andrews \& Schneider, 1983)(Tanenbaum, 1998).
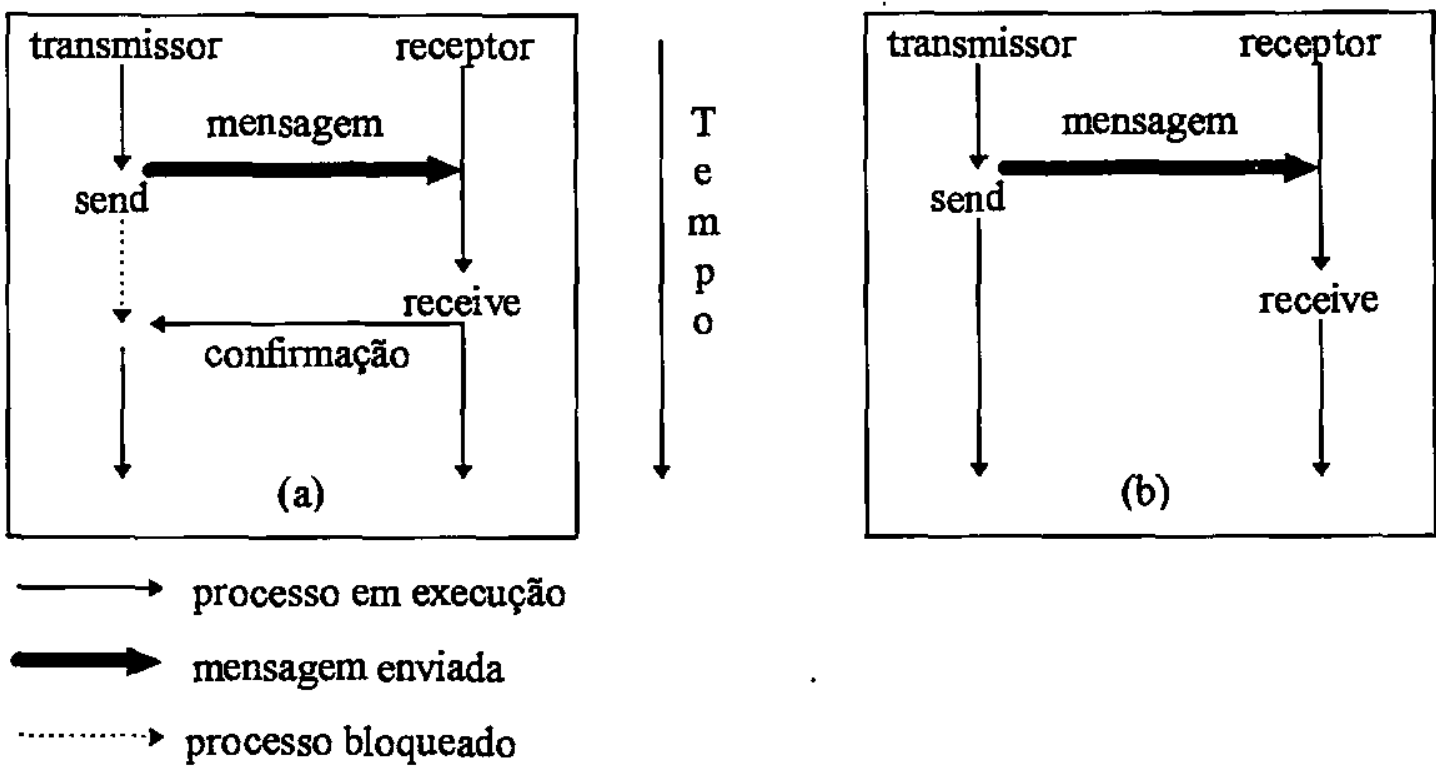

Figura 3.13 - Primitivas send/receive. (a) Bloqueante (b) Não Bloqueante 
Comunicação Ponto a Ponto: caracteriza-se pelo uso de uma operação bloqueante (figura 3.14 (a)). A comunicação é unidirecional, o que permite que os processos se sincronizem.
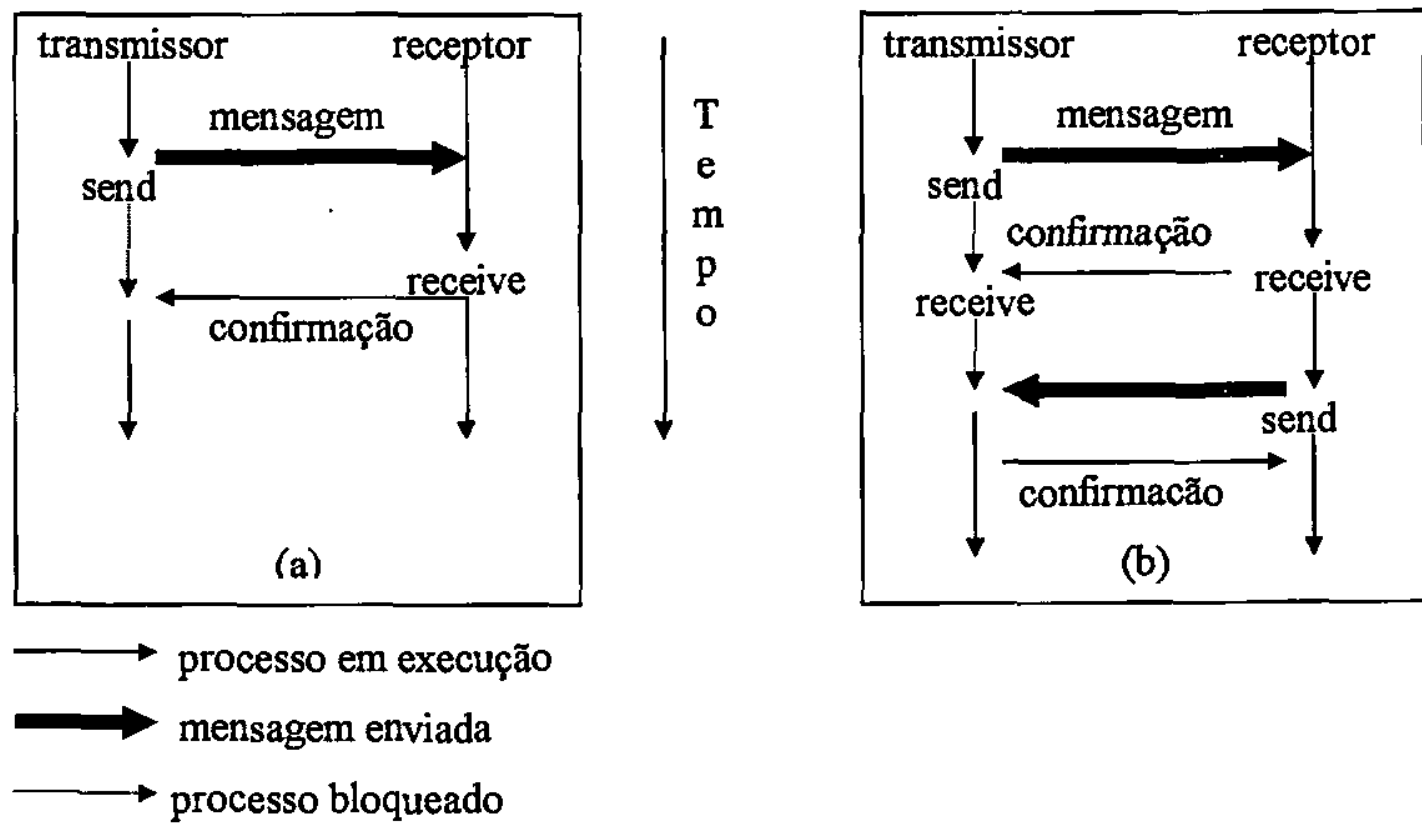

Figura 3.14 - Mecanismos de Comunicação. (a) Ponto a Ponto (b) Rendezvouz.

Rendezvouz: essa estrutura implementa comunicação bidirecional, através do uso de dois conjuntos de operações send/receive bloqueantes (figura 3.14 (b)).

RPC (Remote Procedure Call - Chamada Remota a Procedimento): esse mecanismo permite a comunicação entre processos, através da chamada de uma função que é executada em uma máquina remota (Coulouris et al., 1994). Utiliza uma sintaxe similar à chamada de procedimentos locais, sendo que o processo requisitador do serviço é bloqueado até a obtenção dos resultados desejados (figura 3.15). 


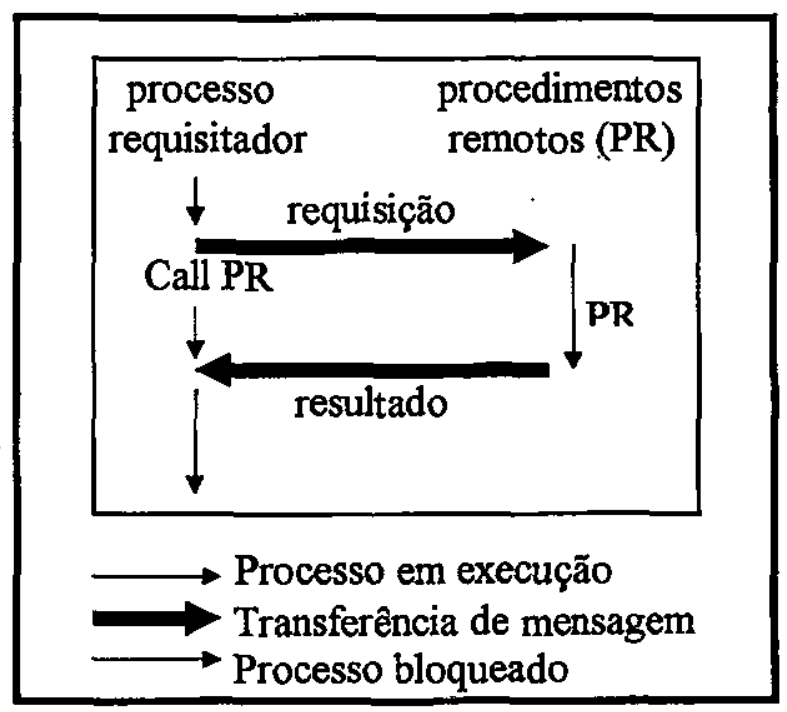

Figura 3.15 - RPC.

\subsection{Suporte à Programação Paralela}

O uso de ferramentas que agrupam os mecanismos para ativação, comunicação e sincronismo de processos concorrentes, torna-se necessário para a construção de programas paralelos.

Vários aspectos influenciam a escolha de uma dessas ferramentas, como por exemplo, o tipo de aplicação, a granulosidade e o tipo de arquitetura a ser utilizada. Segundo Almasi (Almasi \& Gottlieb, 1994), dois fatores devem ser bastante considerados para a escolha de uma dessas ferramentas: o tempo de trabalho do programador (incluindo o tempo de aprendizado da ferramenta) e o desempenho obtido.

Almasi (Almasi \& Gottlieb, 1994) cita três tipos de ferramentas para construção de programas paralelos: ambientes de paralelização automática, extensões para linguagens seriais (linguagens inèrentèmèntè se qüenciäis) e lingüügens concorrentes.

Os ambientes de paralelização automática geram automatıcamente versōes paralelas de programas não paralelos. Esses ambientes exigem esforços mínimos do programador.

As extensões paralelas são bibliotecas que contêm um conjunto de instruções que complementam algumas linguagens seqüenciais (como por exemplo, $\mathrm{C}$ ou Fortran). Esses ambientes requerem algum trabalho do programador, mas se este possuir conhecimento prévio da linguagem, não será necessário o aprendizado de uma nova linguagem. São exemplos de extensões os ambientes 
de passagem de mensagens, geralmente utilizados em arquiteturas com memória distribuída ou sistemas distribuídos. Esses ambientes são discutidos na seção 3.7 (Ambientes de Passagem de Mensagens).

As linguagens concorrentes são desenvolvidas visando a programação concorrente. Elas permitem uma boa estruturação do código e geram programas paralelos de desempenho satisfatório. Occam e $A d a$ são exemplos típicos dessa classe de linguagens.

\subsection{Ambientes de Passagem de Mensagens}

Um procesșador seqùencial é controlado por apenas um programa em um determinado instante. Esse programa determina quais instruções devem ser executadas pelo processador, qual a ordem de execução e quais posições de memória as instruções devem utilizar para realizar um determinado processamento (Mcbryan, 1994).

Por outro lado, uma máquina paralela é muito mais complexa. Geraimente, um computador desse tipo possui um número $P$ de processadores seqüenciais. Caso a memória do sistema seja distribuída, cada processador possui sua própria memória de trabalho, não visível para os demais. $\mathrm{O}$ controle de uma máquina paralela também é feito por um programa, que define e escalona as tarefas executadas por cada um dos $P$ processadores, bem como os dados residentes na memória local de cada um. Logicamente, isso equivale a $P$ programas executando em $P$ processadores, mais um conjunto extra de procedimentos que determina a forma de escalonar tarefas nos $P$ processadores, além de fornecer meios de acesso à memória local de cada processador pelos demais (Mcbryan, 1994).

Um dos muitos paradigmas utilizados para escrever programas para sistemas paralelos é o de passagem de m̌nensăgeñs, qữe apresenta duas características fundamentais para esse tipo de aplicação (Mcbryan, 1994):

- Sincronização de processos.

- Acesso de leitura e/ou gravação à memória local dos processadores.

Um processo faz uso de passagem de mensagens quando ele envia um item qualquer de informação (uma mensagem) residente na memória local de seu processador para um outro processo. Embora esse sistema aparente ser uma forma de acesso apenas para leitura de dados, ele permite 0 
trabalho cooperativo entre vários processos de um sistema, de forma que aquele que recebe uma mensagem pode atualizar dados de sua memória local, permitindo, assim, acesso de leitura e/ou gravação a virtualmente qualquer posição de memória de qualquer processador (Mcbryan, 1994).

Um programa paralelo com passagem de mensagens consiste de $\mathbf{P}$ programas seqüenciais, cada um rodando em seu processador. Cada um desses $\mathbf{P}$ programas utiliza a passagem de mensagens para sincronização e acesso à memória dos demais. Geralmente, o sistema de passagem de mensagens reside em um conjunto reduzido de procedimentos que definem um Ambiente de Passagem de Mensagens. Esses procedimentos tornam-se disponiveis para os programadores na forma de uma Biblioteca de Passagem de Mensagens, que pode ser acrescentada a uma linguagem seqüencial comum (por exemplo, $\mathrm{C}$ ou Fortran), permitindo que programas seqüenciais sejam utilizados sem maiores adaptações para fazer processamento paralelo com alto desempenho (Mcbryan, 1994).

Um Ambiente de Passagem de Mensagens é composto de processadores independentes conectados por uma rede de comunicação, cada um rodando seu próprio processo, que utiliza a passagem de mensagens para se comunicar com os demais processos de um sistema, constituindo um Ambiente Paralelo Virtual, ou seja, uma máquina virtual composta de $\mathbf{P}$ processadores que se comportam como uma máquina de um único processador, mas com $\mathbf{O}$ poder somado de $\mathbf{P}$ processadores (Mcbryan, 1994).

Os primeiros ambientes de troca de mensagens surgiram junto às arquiteturas paralelas com memória distribuída, à medida que os fabricantes lançavam novos modelos no mercado. Um problema gerado com esses ambientes é a falta de compatibilidade entre ambientes de diferentes fabricantes. Alguns exemplos de sistemas incompativeis são: CROS da Caltech, NX1 da Intel, PSE da $n C u b e$, EUI da IBM, CS da Meiko, CMMD da Thinking Machines (Mcbryan, 1994).

Devido à proliferação desses sistemas no mercado, vários grupos foram formados com a finalidade de desenvolver as chamadas plataformas dè portabilidade de passagem de mensagens (Mcbryan, 1994), também conhecidas como ambientes de passagem de mensagens, cujo objetivo é padronizar ambientes de troca de mensagens, possibilitando sua utilização em vários sistemas distintos. Assim, programas escritos sobre uma plataforma são portáveis para outros sistemas. Podem ser citados como exemplos de plataformas de portabilidade: Express, MPI, P4, PARMACS (apresentados na seção 3.8) e PVM, discutido em uma seção à parte (seção 3.9), devido à sua importância para este trabalho. 


\subsection{Exemplos de Ambientes de Passagem de Mensagens}

Esta seção descreve alguns dos ambientes de passagem de mensagens mais conhecidos.

\section{Express}

Esse sistema desenvolvido a partir do projeto Crystalline Operating System da Caltech (Mcbryan, 1994). É um produto comercial da empresa Parasoft. Inicialmente, a idéia da Parasoft era implementar o Express em várias arquiteturas, procurando atingir o maior desempenho possível em cada uma delas. Recentemente, a ênfase do projeto tem sido facilitar a utilização do sistema, tornando transparente ao usuário muitos detalhes inerentes ao Express. Foram produzidos mapeamentos e bibliotecas de comunicação para redes em anel, malha, etc., cada uma delas otimizada para uma plataforma de hardware específica. Também foram introduzidas algumas caracteristicas que, até então, eram ignoradas pela maioria dos sistemas de passagem de mensagens, como por exemplo, tratamento de I/O paralelo e balanceamento de carga estático e dinâmico (Flower \& Kolawa, 1994).

MPI

O MPI (Message Passing Interface - Interface de Passagem de Mensagens) é uma tentativa de padronizar as plataformas de portabilidade desenvolvida em uma série de encontros ocorridos entre novembro de 1992 e janeiro de 1994, realizados pelo MPI Committee (um grupo de especialistas oriundos de cerca de 40 organizações, a maioria dos Estados Unidos e Europa) (Mcbryan, 1994).

A meta do MPI Committee é atingir um padrão que considere as melhores características de todas as plataformas e sistemas existentes, permitindo alto desempenho independente do sistema utilizado. Na prática, algumas características tiveram que ser excluídas do projeto por serem incompatíveis com as demais. No entanto, o grande número de envolvidos possibilitou que esse padrão fosse bem aceito (Mcbryan, 1994).

Sua aplicação principal é em computadores MIMD com memória distribuída. O projeto original não apresenta suporte à tolerância a falhas, assumindo que a rede de comunicação é confiável (Walker, 1994). 


\subsection{PVM (Parallel Virtual Machine)}

PVM é um conjunto integrado de bibliotecas de funçōes e de ferramentas de software, cuja finalidade é emular um sistema computacional concorrente, heterogêneo, flexível e de propósito geral (Beguelin, 1994).

O PVM nasceu com o objetivo de permitir que um grupo de computadores conectados, possivelmente com diferentes arquiteturas, possa trabalhar cooperativamente formando uma máquina paralela virtual (Geist, 1994).

O projeto PVM teve início em 1989 no Oak Ridge National Laboratory - ORNL. O protótipo (versão 1.0) foi implementado por Vaidy Sunderam e $A l$ Geist, e teve sua utilização restrita ao ORNL. Em 1991, na versão 2 do PVM, houve participação de outras instituições, como a University of Tennessee, Carnegie Mellon University. A versão 2 deu início à distribuição gratuita do PVM. Após várias revisões (PVM 2.1 - 2.4), o PVM foi completamente reescrito, culminando na versão 3.0. A versão mais recente disponível é PVM 3.3, na qual foram realizadas 10 revisões durante o ano de 1995.

O sistema PVM permite que sejam escritas aplicações nas linguagens Fortran, $\mathrm{C}$ ou $\mathrm{C}^{++}$. A escolha por esse conjunto de linguagens deve-se ao fato de que a maioria das aplicações passiveis de paralelização estão escritas nessas linguagens (Souza, 1996).

O modelo de implementação, também inalterado desde a primeira versão, utiliza o conceito de host ${ }^{\prime 0}$ pool, um conjunto de computadores interligados (configurado pelo usuário) formando uma máquina virtual, na qual um grupo de processos daemon ${ }^{l l}$ (pvmd) coopera entre si para emular um sistema computacional concorrente. As aplicações que executam em uma máquina virtual requisitam serviços e recebem as respostas dos daemons.

Basicamente, os serviços disponíveis em um sistema PVM podem ser divididos nas seguintes categorias (Beguelin, 1994)(Geist, 1994)(Sunderan et al., 1994):

\footnotetext{
${ }^{10} \mathrm{O}$ termo host é utilizado para designar qualquer um dos elementos de processamento (por exemplo uma estação de trabalho) que compõe a máquina virtual.

${ }^{11}$ De acordo com a terminologia UNIX, deamon é um processo que é executado em background, atendendo requisiçōes e/ou disponibilizando determinados serviços.
} 
- Gerenciamento de processos.

- Configuração da máquina virtual.

- Passagem de mensagens.

- Sincronização.

\subsubsection{O Modelo PVM}

No PVM, um conjunto de computadores seriais, paralelos ou vetoriais emula um grande computador de memória distribuída (a máquina virtual). Vários usuários podem definir máquinas virtuais na mesma rede, não necessariamente coincidentes, podendo ser sobrepostas. O PVM fornece as funções que permitem ao usuário iniciar, comunicar e sincronizar tarefas (tasks) na máquina virtual. Cada usuário pode executar várias aplicações PVM simultaneamente. Uma tarefa é definida como uma unidade computacional semelhante a um processo UNIX. Ao enviar e receber mensagens, várias tarefas de uma aplicação podem cooperar para resolver um problema em paralelo. $O$ modelo assume que qualquer tarefa pode enviar uma mensagem para qualquer outra e que não há limites para o tamanho ou número de tais mensagens (Beguelin, 1994)(Sunderan et al., 1994).

O modelo computacional do PVM é , portanto, baseado na noção de que uma aplicação consiste de várias tarefas. Cada tarefa é responsável por uma parte da carga de trabalho da aplicação.

Uma aplicação pode ser paralelizada por dois métodos: o paralelismo funcional e o paralelismo de dados. No paralelismo funcional (também conhecido como paradigma mestreescravo), a aplicação é dividida através das suas funções, isto é, cada tarefa desempenha um serviço diferente, como por exemplo entrada, processamento e saída.

O paralelismo de dados refere-se ao paradigma SPMD (Single Program / Multiple Data), baseado na distribuição do mesmo código fonte entre os processadores, cada processador executando o código fonte de maneira independente. Assim, partes distintas do código fonte são executadas por cada processador, dependendo dos dados (Foster, 1995). 
O PVM permite qualquer um dos métodos, como também um método híbrido (uma mistura dos dois). A figura 3.16 ilustra um exemplo do modelo computacional do PVM e uma visão arquitetural destacando a heterogeneidade do sistema.

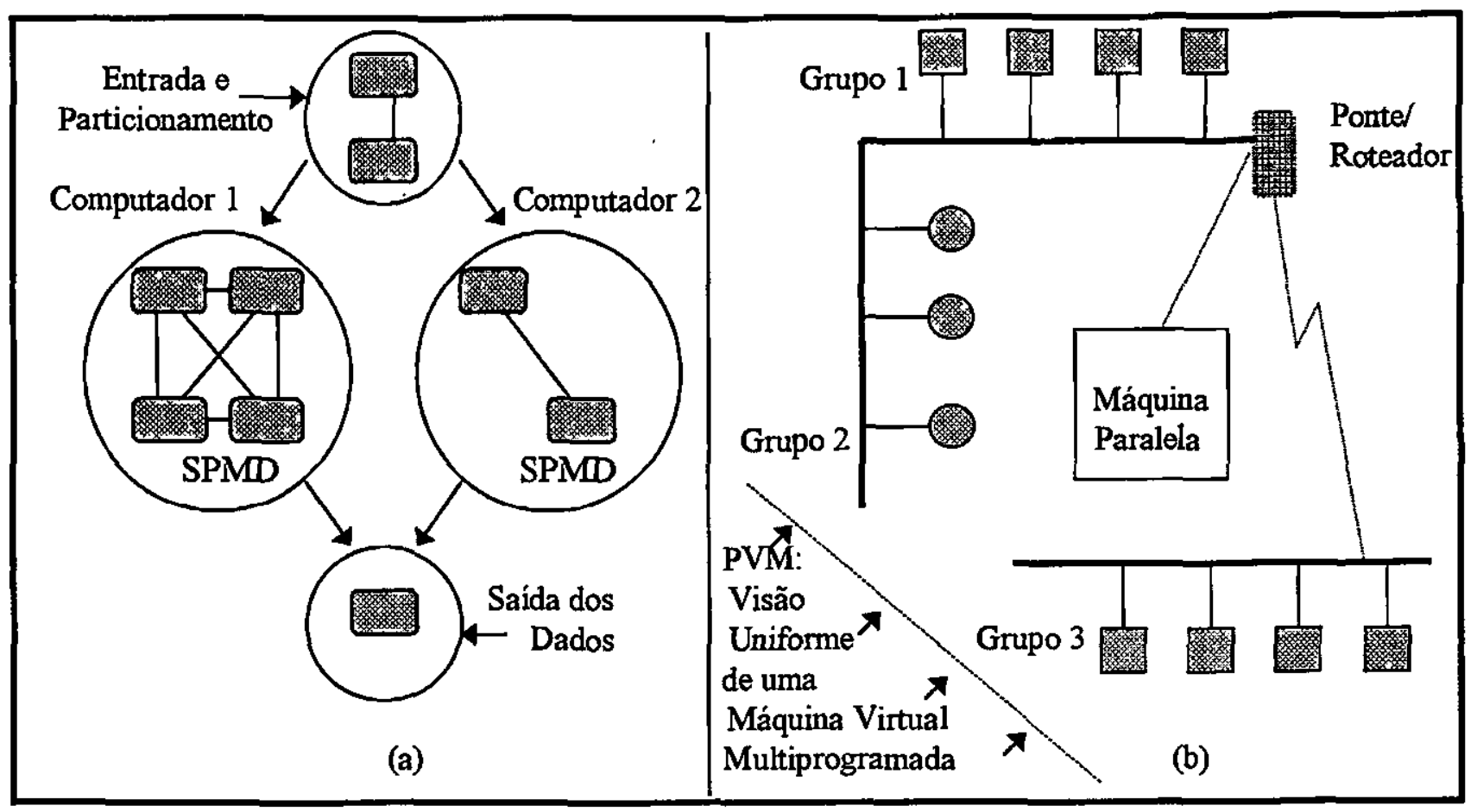

Figura 3.16 - Sistema PVM. (a) Modelo Computacional. (b) Visão Arquitetural

\subsubsection{Componentes}

O sistema PVM é baseado em duas partes (Geist, 1994): daemon (Pvmd) e uma biblioteca de rotinas com a interface PVM (Libpvm).

O Pvmd foi projetado para ser instalado por qualquer usuário com um login válido. Quando um úsuário deseja executâr ùma aplicạçāo PVM, ele primeiro deve criar a máquina virtuat,-iniciandoa com o Pvmd. O Pvmd é executado em cada host que compõe a máquina virtual (computador lógico com memória distribuída) atuando como "gerenciador" da máquina e roteador de mensagens. 0 primeiro Pvmd (iniciado pelo usuário) é designado como mestre (master), enquanto os outros (iniciados pelo mestre) são chamados escravos (slaves) (Souza, 1996). A diferença entre mestre e escravos só se evidencia quando há necessidade de operações de gerenciamento, como criar novos Pvmds escravos e adicioná-los à máquina virtual, pois só o mestre pode realizar essa tarefa. As 
principais estruturas de dados do Pvmd são as tabelas de hosts que descrevem a configuração da máquina virtual e a de tarefas que determinam as tarefas que estão sendo executadas. É importante lembrar que o Pvmd não faz nenhum processamento, e sim roteamento e controle de mensagens, funcionando como um ponto de contato em cada host, autenticando mensagens, fazendo o controle de processos e detectando falhas.

Libpvm foi desenvolvida para ser tão pequena quanto possível, visto que ela compartilha 0 espaço de endereçamento com o código desenvolvido pelo usuário. As rotinas pertencentes à Libpvm podem ser chamadas pelo usuário para efetuar troca de mensagens, solicitar a geração de processos, coordenação de tarefas e solicitar modificações na máquina virtual. A interface com o usuário é de responsabilidade das funções de nível mais alto (que são independentes da plataforma), enquanto que as funções de mais baixo nível (que são dependentes de plataforma) encontram-se separadas das demais, com o objetivo de permitir substituição quando há mudança de plataforma. A Libpvm contém um conjunto de primitivas que atua como elo de ligação entre uma tarefa e a máquina virtual (o Pvmd e as outras tarefas) (Souza, 1996).

\subsubsection{Comunicação no PVM}

O processo de envio de uma mensagem no PVM envolve três fases principais: a criação do buffer de envio, a preparação da mensagem (packing) e o envio efetivo da mensagem para a outra tarefa. A tarefa receptora recebe a mensagem através de um função que retira a mensagem do buffer, residente no host receptor da mensagem (Beguelin, 1994).

As formas de comunicação existentes no PVM são o send bloqueante assíncrono, receive bloqueante assíncrono e receive não bloqueante.

- send bloqueante assíncrono retorna-tão logo o buffer de transmissão-esteja disponivel para ser utilizado novamente pela aplicação, não dependendo da execução de um receive para poder retornar. O send bloqueia o processo quando o tamanho da mensagem exceder o tamanho do buffer de envio e precisar ser dividida. Nesse caso, é necessário que o host receptor execute um receive para liberar o buffer, permitindo assim a continuidade no envio da mensagem. 
O receive bloqueante retorna apenas quando existem dados no buffer de recepção. A versão não bloqueante dessa função permite que apenas seja verificado esse buffer, retornando uma variável (flag) que indica se existem ou não mensagens no buffer.

Além da comunicação ponto-a-ponto, o PVM disponibiliza para a aplicação as formas broadcasting (envio de uma mensagem para um grupo de tarefas definido pelo usuário) e multicasting (envio de uma mensagem para um conjunto de tarefas) para envio de mensagens. A comunicação realizada pelo PVM é implementada através dos protocolos TCP (Transmission Control Protocol) e UDP (User Datagram Protocol), utilizando como ponto de acesso a interface de sockets.

O protocolo TCP é utilizado para a comunicação entre as tarefas e o PVM daemon, devido à confiabilidade que esse protocolo possui. Já a comunicação entre os PVM daemon é implementada utilizando o protocolo UDP. Para esse caso não foi utilizado o protocolo TCP por três motivos principais (Beguelin, 1994):

- O primeiro é a consideração do crescimento em escala, pois o TCP consome um descritor de arquivos para cada transmissão aberta, recurso que é limitado em alguns sistemas operacionais. Utilizando o protocolo UDP, um descritor aberto (socket) pode comunicarse com qualquer outro socket remoto;

- O segundo é o tempo extra necessário para estabelecer uma conexão TCP, que é significativo, principalmente durante a troca de mensagens de tamanho pequeno;

- O último motivo é a tolerância a falhas. São utilizados timeouts para verificar se um PVM daemon está com problemas. O protocolo TCP possui algumas opções para realizar esse trabalho, mas não existe uma flexibilidade adequada no que diz respeito ao controle dos parâmetros.

$\mathrm{O}$ padrão $\mathrm{XDR}^{12}$ é utilizado quando existe a comunicação em ambientes heterogêneos. Essa utilização é muitas vezes necessária e gera tempos adicionais na transmissão da mensagem, devido às

\footnotetext{
${ }^{12}$ A Representação de Dados Externa (XDR - External Data R Representation), é um padrão de representação de dados desenvolvido pela SUN Microsystems, Inc., para a troca de mensagens entre cllentes e servidores quando estes não são do mesmo tipo (Stevens, 1990). Quando uma mensagem é enviada, ela é convertida em uma forma externa ao sistema de origem (padrão XDR, por exemplo), transmitida pela rede de comunicação e, quando recebida, é transformada no formato reconhecido pela máquina destino.
} 
sobrecargas impostas para a codificação da mensagem pelo processo emissor e a decodificação da mensagem pelo processo receptor.

\subsubsection{PVM em Sistemas com Multiprocessadores}

Inicialmente desenvolvido para estações de trabalho UNIX, o PVM pode ser utilizado também em máquinas multiprocessadas, com memória distribuída ou memória compartilhada (Beguelin, 1994).

No caso de máquinas multiprocessadas com memória distribuída, a portabilidade da aplicação é conseguida de maneira natural, devido ao fato de que as funções para passagem de mensagens no PVM são mapeadas diretamente para as chamadas do sistema (system calls) próprias dessas arquiteturas.

Em máquinas multiprocessadas com memória compartilhada, a passagem de mensagens pode ser efetuada através da utilização de buffers residentes na memória compartilhada. $O$ acesso a esses buffers deve ser sincronizado através de travas (locks) que implementam exclusão mútua.

\subsubsection{Importância da Utilização do PVM}

O PVM é um ambiente de passagem de mensagens, desenvolvido inicialmente para atuar sobre grupos de estações de trabalho e com o sistema operacional UNIX (Geist, 1994) (Beguelin, 1994) (Sunderan et al., 1994). Atualmente o PVM é considerado um dos mais importantes ambientes de passagem de mensagens desenvolvidos, devido à sua vasta utilização pela comunidade científica e comercial.

\subsection{Considerações Finais}

A necessidade de aumentar o desempenho da potência computacional, surgiu devido à natureza limitada das arquiteturas seqüenciais de von Neumann. Uma alternativa interessante para solucionar os problemas de limitações foi o desenvolvimento de arquiteturas paralelas. Neste 
contexto, várias classificações foram propostas. Duas classificações se destacam na literatura: a classificação de Flynn e a classificação de Duncan.

A classificação de Flynn, que considera o fluxo de instruções e de dados, é composta por quatro grupos: SISD, SIMD, MISD e MIMD. Por mais que seja considerada limitada e antiga no mundo da computação (1972), essa classificação continua bastante difundida. Duncan elaborou sua classificação a fim de resolver os problemas surgidos com a classificação de Flynn e acrescentar novas arquiteturas paralelas.

Entretanto, para o êxito da computação paralela foi necessária a implementação de novas técnicas e ferramentas destinadas ao processamento paralelo. Linguagens para programação concorrente, extensões e ambientes de passagens de mensagens foram construídos para fornecer suporte à programação concorrente.

$\mathrm{O}$ modelo arquitetural MIMD com memória distribuída tem se destacado nos últimos anos, essa preferência se deve, sobretudo, à sua flexibilidade e facilidade de ampliação (Blech, 1994)(Mcbryan, 1994) (Zaluska, 1991).

Um dos grandes problemas relacionados à computação paralela é a portabilidade de programas paralelos sobre arquiteturas paralelas diferentes ou ambientes heterogêneos que podem funcionar como ambiente de computação paralela, como por exemplo sistemas distribuídos. Com o objetivo de minimizar o impacto da utilização de computação paralela, foram desenvọlvidos ambientes de troca mensagens, que viabilizam a comunicação e sincronismo entre processos paralelos. O grande problema desses ambientes está na sua padronização. Para isso, é importante um esforço da indústria no sentido de padronizar esses ambientes, reduzindo os custos de desenvolvimento das aplicações que utilizam passagem de mensagens. 


\section{Capítulo 4}

\section{Simulação Distribuída}

Este capitulo aborda os mecanismos necessários para a implementação de uma simulação distributda. O protocolo CMB, proposto por Misra (Misra, 1986), juntamente com algumas técnicas de recuperação de deadlock ${ }^{l 3}$, são discutidos neste capitulo.

\subsection{Introdução}

As limitações das técnicas matemáticas encontram-se no grande número de restrições que devem ser impostas aos sistemas, para que os resultados sejam confiáveis. Essas restrições acabam resultando em análises pouco realistas (Gonçalves, 1989).

A avaliação de desempenho de sistemas computacionais pode seguir diferentes abordagens. De uma maneira geral, as técnicas para avaliação de desempenho de um sistema computacional podem ser agrupadas em duas grandes classes (Orlandi, 1995): As técnicas de aferição e de modelagem. São exemplos de técnicas de aferição: os protótipos, os benchmarks e a coleta de dados. Como exemplo de modelagem, têm-se as Redes de Fila e as Redes de Petri (Maciel et al., 1996). Uma melhor abordagem sobre as técnicas de avaliação de desempenho pode ser encontrada em (Francês, 1998).

Se a avaliação se processa através de modelagem, deve-se escolher um método para resolução do modelo. Existem duas técnicas para resolver um modelo: a solução analítica e a solução por simulação. Ambas possuem vantagens e desvantagens, mas, de um modo geral, a escolha entre

\footnotetext{
${ }^{13}$ Segundo Tanenbaum (Tanenbaum, 1998), deadlock é formalmente definido da seguinte maneira:

"Um conjunto de processos encontra-se em deadlock se cada processo pertencente ao conjunto está esperando por um evento que nunca ocorre, pois apenas outro processo do conjunto, que também está esperando por um evento, pode causar o evento esperado."

Devido ao fato de todos os processos estarem esperando, nenhum deles irá realizar uma ação que faça com que um deles desperte, e então, todos irão permanecer esperando indefinidadmente.
} 
uma delas está relacionada ao número de informações que o sistema deve manipular e a complexidade inerente a esse sistema. Se o número de informaçōes e a complexidade são razoavelmente pequenas, via de regra, a solução analítica pode ser mais viável e mais exata. Porém, se há um grande conjunto de informações e uma alta complexidade no sistema que se deseja representar através de um modelo, geralmente, a simulação representa uma melhor proposta de solução. Tanto solução analítica como por simulação apresentam problemas.

Se a escolha de solução for pela simulação, o problema mais crítico se encontra no grande esforço computacional necessário para a execução de uma simulação realista. Às vezes, o tempo de processamento torna-se inviável. Nesses casos, a utilização de simulação distribuída vem, paulatinamente, substituindo a simulação seqüencial.

Tradicionalmente, a simulação seqüencial utiliza três estruturas de dados básicas:

- As variáveis de estado que descrevem o estado do sistema;

- Uma lista de eventos (denominada lista de eventos futuros) que armazena todos os eventos pendentes que foram escalonados para a execução;

- Um relógio global que controla o andamento da simulação.

Cada evento possui um timestamp (tempo de chegada do evento em um processo) e determina alguma alteração no estado do sistema simulado. O timestamp determina quando essa mudança deve ocorrer. A lista de eventos futuros é classificada em ordem ascendente do tempo de ocorrência dos eventos. $O$ programa de simulação repetidamente remove o evento com menor timestamp (da cabeça da lista) para executá-lo. Quando o programa completa todo o processamento em um determinado instante do tempo, o próximo evento com menor tempo associado é removido da cabeça da lista. Nesse momento, o relógio é avançado para o tempo de ocorrência desse evento, e o programa de simulação inicia a execução do evento (Fujimoto, 1990)(MacDougall, 1987). Esse mecanismo garante que os eventos no sistema fisico sejam simulados em ordem cronológica no tempo de simulação. 
Contudo, apesar das vantagens oferecidas pela simulação (como flexibilidade, baixo custo, entre outras), algumas dessas características limitam a sua aplicação. A simulação distribuída surgiu com o intuito de melhorar essa aplicabilidade.

A simulação distribuída explora a utilização de máquinas paralelas, ou ambientes distribuídos, com vários processadores e alta capacidade de comunicação (Fujimoto, 1990)(Nicol \& Fujimoto, 1995)(Misra, 1986).

Para possibilitar a utilização de diversos processadores na execução de uma simulação, faz-se necessário adaptar a simulação seqüencial para essa nova situação. $O$ problema da simulação distribuída está na natureza seqüencial da lista de eventos futuros. Um único evento é retirado da lista para ser executado. Esse evento pode gerar novos eventos com diferentes localizações na lista. Tal mecanismo torna dificil a execução concorrente dos eventos, uma vez que a lista de eventos futuros não pode ser efetivamente particionada, pois a existência de uma lista de eventos posicionados cronologicamente impõe uma simulação seqüencial, onde apenas um evento é simulado por vez.

Outro. problema crítico na simulação distribuída é o sincronismo entre os processos. Para solucionar esse problema, diferentes protocolos têm sido propostos. A maioria deles são extensões do protocolo conservativo CMB (discutido na seção 4.3) e do protocolo otimista Time Warp (especificamente abordado no capítulo 5 , devido à sua importância e utilização neste trabalho).

\subsection{Simulação Distribuída}

A idéia de simulação distribuída foi proposta por Chandy em 1977, em uma série de conferências na Universidade de Waterloo, e independentemente por R. E. Bryant (Misra, 1986).

A simulação distribuída é constituída por um conjunto de processos lógicos $L_{p_{0}}, L_{p_{1}}, \ldots, L p_{n}$, cada um representando um processo físico $(\mathrm{Pp})$ do sistema real. As interações entre os processos físicos são modeladas por mensagens (eventos com timestamp) entre os processos lógicos correspondentes, de acordo com a ordem seqüencial imposta pelo tempo no sistema real (Fujimoto, 1990). As mensagens transitam entre os processos através de canais de comunicação.

Uma regra rígida da simulação é que todo o processamento dos eventos deve ser semelhante ao comportamento do sistema real, não permitindo que os relacionamentos de causalidade dos eventos sejam violados. Por exemplo, em um sistema real sendo simulado, o evento $\mathrm{E}_{1}$ ocorre antes 
do evento $E_{2}$. Quando for simular esse sistema real, a ordem de ocorrência dos eventos deve ser obedecida: $E_{1}$ deve ser tratado antes de $E_{2}$. Se na simulação o evento $E_{2}$ for simulado antes do evento $E_{1}$ (o futuro afetando o passado), tem-se um erro, violando-se a relação de causalidade (Fujimoto, 1990).

Considere o seguinte exemplo: o processo lógico ${ }_{1}\left(\mathrm{Lp}_{1}\right)$ executa o evento $\mathrm{E}_{1}$ com timestamp 10 e o processo lógico ${ }_{2}\left(\mathrm{~L}_{2}\right)$ executa o evento $\mathrm{E}_{2}$ com timestamp 20 (figura 4.1 (a)). Se $\mathrm{E}_{1}$ escalona um novo evento $\mathrm{E}_{3}$ para $\circ \mathrm{Lp}_{2}$ com timestamp menor que $20, \mathrm{E}_{3}$ pode afetar o evento $\mathrm{E}_{2}$, sendo necessária a execução seqüencial dos três eventos (figura 4.1 (b)) (Fujimoto, 1990)(Overeinder et al., 1991).

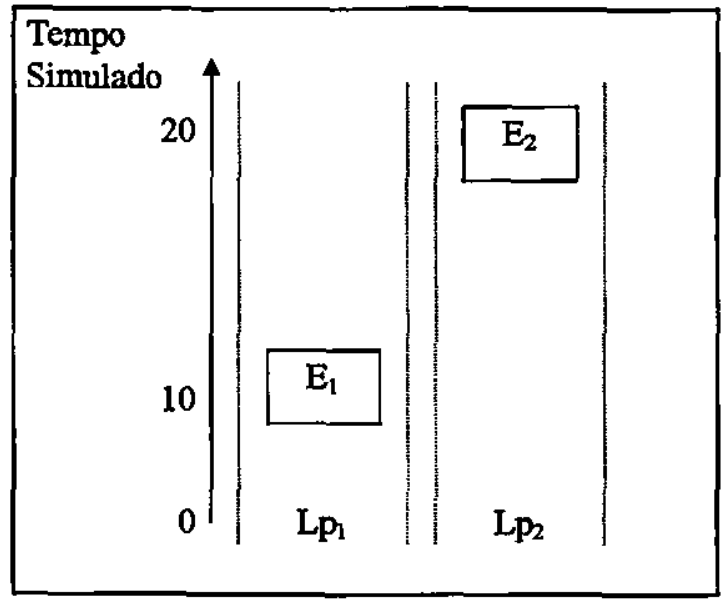

(a)

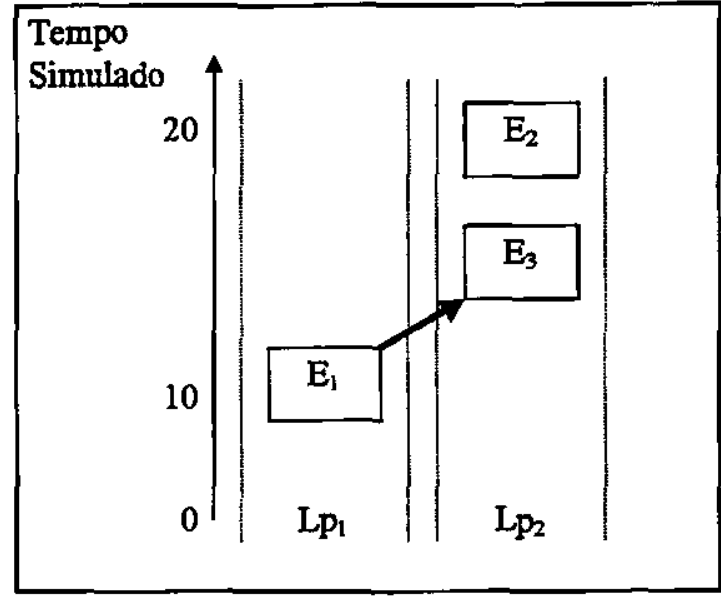

(b)

Figura 4.1 - (a) (b) - Ocorrência de Erros de Causalidade

Como já mencionado na seção anterior, diversos protocolos têm sido desenvolvidos para solucionar o problema de sincronismo entre os processos de uma simulação distribuida.

A simulação distribuída oferece diversas vantagens sobre a simulação seqüencial: além do speedup, requer pouca memória adicional comparada à simulação seqüencial (pelo menos, em relação ao protocolo conservativo $\mathrm{CMB}$ ), exige pouco controle global exercido por qualquer máquina e a simulação de um sistema pode ser adaptada à estrutura do hardware disponível (com poucas 
máquinas, diversos processos fisicos podem ser simulados em um único processador) (Fujimoto, 1990) (Misra, 1986).

\subsection{Protocolos para Sincronização em Șimulação Distribuída}

Os protocolos para sincronização em simulação distribuída são classificados em duas categorias: os conservativos e os otimistas. Os mecanismos conservativos evitam a possibilidade da ocorrência de violação de causalidade, determinando quando é seguro processar um evento. Essa segurança é constatada se todos os eventos que poderiam afetar o evento corrente já foram processados. Já os mecanismos otimistas utilizam a estratégia de deteç̧ão e recuperação: violações de causalidade são detectadas e um mecanismo, chamado rollback, é utilizado na recuperação desse erro (Fujimoto, 1990).

A seguir são discutidos o protocolo conservativo CMB e alguns tópicos relacionados a ele: Prevenção do Deadlock (Chandy \& Misra, 1979)(Bryant, 1977), Transmissão de Mensagens Nulas sob Demanda (Chandy \& Misra, 1981)(Misra, 1986), Detecção e Recuperação de Deadlock e Lookahead (Chandy \& Misra, 1981)(Fujimoto, 1990). O capitulo 5 aborda especificamente o protocolo otimista Time Warp, o qual é o tópico central deste trabalho.

\subsubsection{O Protocolo CMB (Prevenção de Deadlock utilizando Mensagens Nulas)}

O CMB exige que se especifique estaticamente os canais que estabelecem comunicação entre os processos. Quando se fizer referência a processo, estará subentendido que está-se referindo a processo lógico $(\mathrm{Lp})$. Para determinar quando é seguro processar um evento, é necessário que a seqüência dos timestamps das mensagens enviadas através de um canal seja não decrescente.

As mensagens que chegam em cada canal de entrada de um processo são armazenadas em ordem FIFO (First-In, First-Out), que também é a ordem dos timestamps. Cada canal tem um relógio, que assume o componente $t$ da última mensagem recebida através desse canal. O relógio terá valor zero se nenhuma mensagem tiver sido recebida através do canal. O relógio do processo (também denominado Tempo Virtual Local ou LVT) é sempre o menor valor entre os relógios dos seus canais de entrada (Fernandes, 1994)(Misra, 1986). 
O processo $A$, representado na figura 4.2 , tem canais de entrada $\mathrm{Cl}, \mathrm{C} 2$ e $\mathrm{C} 3$ e apresentam, respectivamente, LVT's iguais a 11, 2 e 5 . O menor valor do tempo de recebimento de mensagens é igual a 2 (canal C2). Portanto o LVT do processo $A$ é igual a 2 e o processo $A$ pode seguramente prosseguir sua execução até esse tempo.

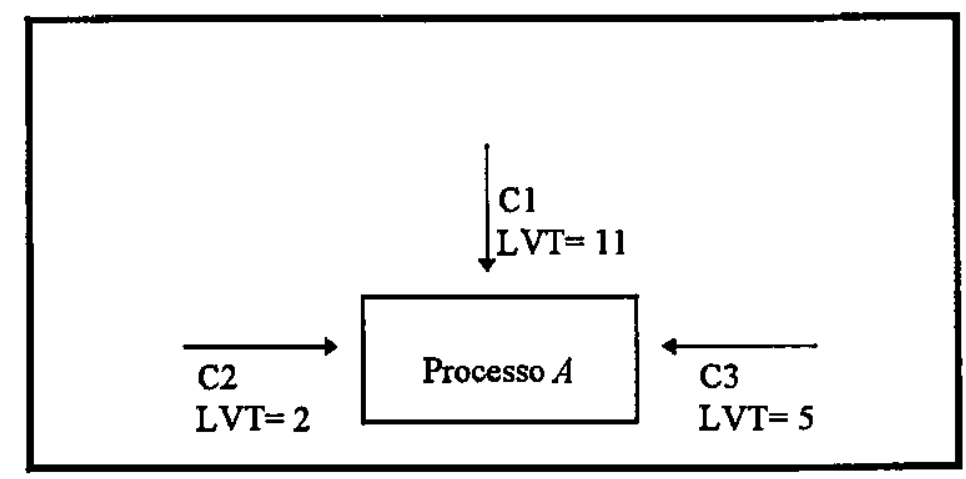

Figura 4.2 - LVT do Processo $A$

O valor do relógio da simulação $(T)$ é o menor valor de LVT de todos os processos. Pode-se declarar que em um determinado ponto da simulação, o sistema fisico tenha sido simulado até o ponto indicado por $T$, mesmo que algum processo tenha simulado seu correspondente processo fisico (Pp) até um tempo major que $T$ (Morselli, 1995).

O processo repetidamente seleciona o canal com o menor LVT e se houver uma mensagem na fila, esta é processada. Caso contrário (fila vazia), o processo fica bloqueado. Esse protocolo garante apenas que cada processo tratará os eventos em ordem não decrescente de timestamps.

Um problema crítico nesse protocolo é demonstrado na figura 4.3, onde cada processo fica indefinidamente esperando uma mensagem no canal de entrada que contém o menor valor de LVT, uma vez que a fila correspondente encontra-se vazia. Todos os três processos estão bloqueados, embora existam mensagens em outras filas de entrada de cada processo, aguardando para serem processadas (Fujimoto, 1990).

Misra, em (Misra, 1986), define que um conjunto D de processos encontra-se em deadlock em um mesmo ponto de execução se todas as condições seguintes forem satisfeitas:

- Todo Lp, pertencente a D, está esperando uma mensagem ou encerrou sua execução;

- No mínimo um Lp, pertencente a $D$, está esperando uma mensagem; 
- $U m L_{p_{i}}$ qualquer, pertencente a $D$, está esperando uma mensagem de algum $L_{p_{j}}$ (também pertencente a $D$ ), e não existe mensagem em trânsito de $L p_{j}$ para $L p_{i}$.

Essas condições garantem que nenhum processo pertencente a $\mathrm{D}$ irá executar qualquer tipo de processamento, já que cada um deles está esperando a realização de algum evento por outro processo (Misra, 1986).

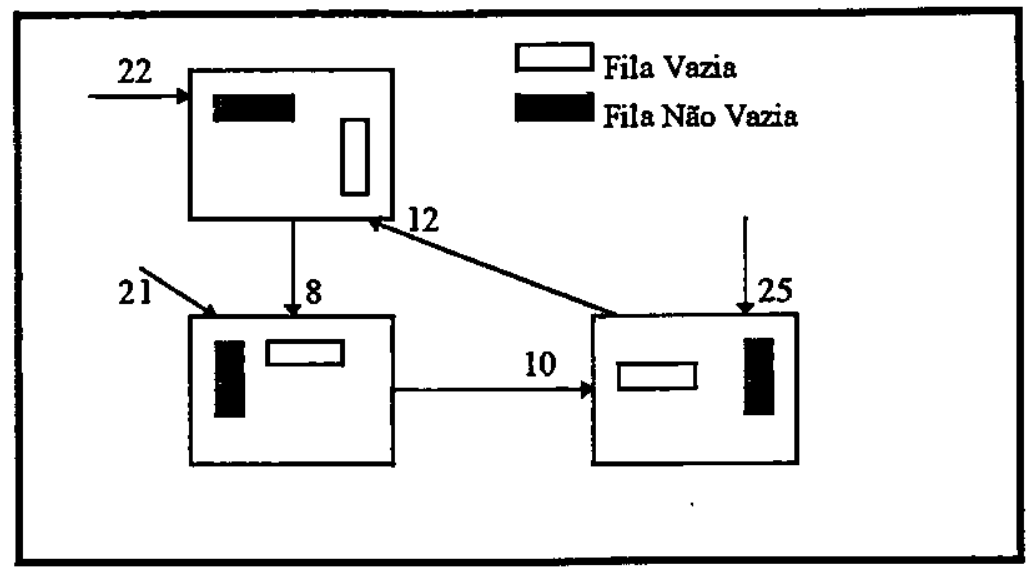

Figura 4.3 - Situação de Deadlock

Para evitar que a simulação entre em deadlock, foi desenvolvido um mecanismo que utiliza mensagens nulas (Misra, 1986).

\section{Prevenção do Deadlock Utilizando Mensagens Nulas}

Esse mecanismo evita a ocorrência de deadlock através da utilização de mensagens nulas. Estas são usadas apenas com o propósito de sincronização e não correspondem às atividades no sistema fisico. Uma mensagem nula com timestamp $t$, enviada por um $L p_{i}$ para $u m L p_{j}$, indica que $L p_{i}$ não enviará mensagens para $L_{p_{j}}$ entre o valor corrente do relógio e o tempo $t$. Por essa razão, qualquer mensagem futura do $\mathrm{L}_{\mathrm{i}}$ para $\circ \mathrm{L}_{\mathrm{j}}$ terá timestamp superior a $t$. 
Como já mencionado anteriormente, $\mathrm{LVT}_{\mathrm{i}}$ indica o valor do relógio do $\mathrm{Lp}_{\mathrm{i}}$. Quando $\mathrm{Lp}_{\mathrm{i}}$ recebe uma mensagem, ele próprio atualiza seu LVT. Se o LVT é alterado, $L \mathrm{p}_{i}$ avança a simulação do processo físico correspondente até o valor de LVT. Nesse instante, $L \mathrm{p}_{\mathrm{i}}$ prediz para cada canal de saída uma seqüência de mensagens que o processo físico possa ter enviado, gerando uma seqüência de mensagens para transmitir para $\mathrm{Lp}_{\mathrm{j}}$, para cada $\mathrm{j}$ no qual exista um canal de entrada.

Suponha que o $\mathrm{Lp}_{\mathrm{i}}$ possa futuramente predizer que após a transmissão dessa seqüência de mensagens o processo físico "i”" não irá enviar mensagens ao processo fisico “j” até o tempo $t_{j}$. Nesse caso, $\mathrm{Lp}_{\mathrm{i}}$ envia a mensagem ( $t$, nula) ao $\mathrm{L}_{\mathrm{j}}$ depois de ter enviado a seqüência correta de mensagens. Uma vez que $\mathrm{Lp}_{\mathrm{i}}$ conhece o estado do seu processo físico correspondente até o tempo $\mathrm{LVT}_{\mathrm{i}}$, ele pode prognosticar todas as mensagens (que estão sendo enviadas) e também detectar a ausência de mensagens, no mínimo até o $\mathrm{LVT}_{\mathfrak{i}}$. Nesse caso, todo canal de saída possuirá a última mensagem com o componente tempo igual ou maior que $\mathrm{LVT}_{\mathrm{i}}$.

Mensagens nulas são tratadas como qualquer mensagem quando recebidas por um processo: a recepção de uma mensagem nula faz com que o Lp atualize seu LVT.

\subsubsection{Transmissão de Mensagens Nulas Sob Demanda}

Uma desvantagem do protocolo CMB é a sobrecarga (overhead) gerada pelas mensagens nulas. Uma variação desse protocolo é enviar mensagens nulas sob demanda (Chandy \& Misra, 1981), e não após o processamento de cada evento. A freqüência dessa demanda pode ser dada por um timeout ou também quando o menor relógio de todos os canais for o de uma fila vazia (indicando que o processo encontra-se bloqueado). Quando isso ocorrer, a próxima mensagem é requisitada (pode ser uma mensagem nula ou não) ao processo que envia para esse canal. $O$ processo continua sua execução quando a resposta a esse pedido for recebida.

Considere o seguinte exemplo (Chandy \& Misra, 1981): o $\mathrm{Lp}_{1}$ requisita ao $\mathrm{Lp}_{2}$ que aumente o valor do relógio do canal que conecta os dois processos. Esse avanço é possivel se o valor do relógio desse canal for menor que o valor atual do LVT de $\mathrm{Lp}_{2}$ (mínimo entre os relógios dos canais de entrada de $\mathrm{L}_{2}$ ). Nesse caso, $\mathrm{Lp}_{2}$ envia uma mensagem, possivelmente nula, avançando o relógio do canal 2. A figura 4.4 (a) ilustra o exemplo. $\mathrm{O} \mathrm{L} \mathrm{p}_{2}$ pode enviar uma mensagem ao $\mathrm{Lp}_{1}$, incrementando 
o relógio do canal 2 para 12. Com isso, o Lp1 pode computar o novo valor do seu LVT (igual a 9) e prosseguir sua execução.

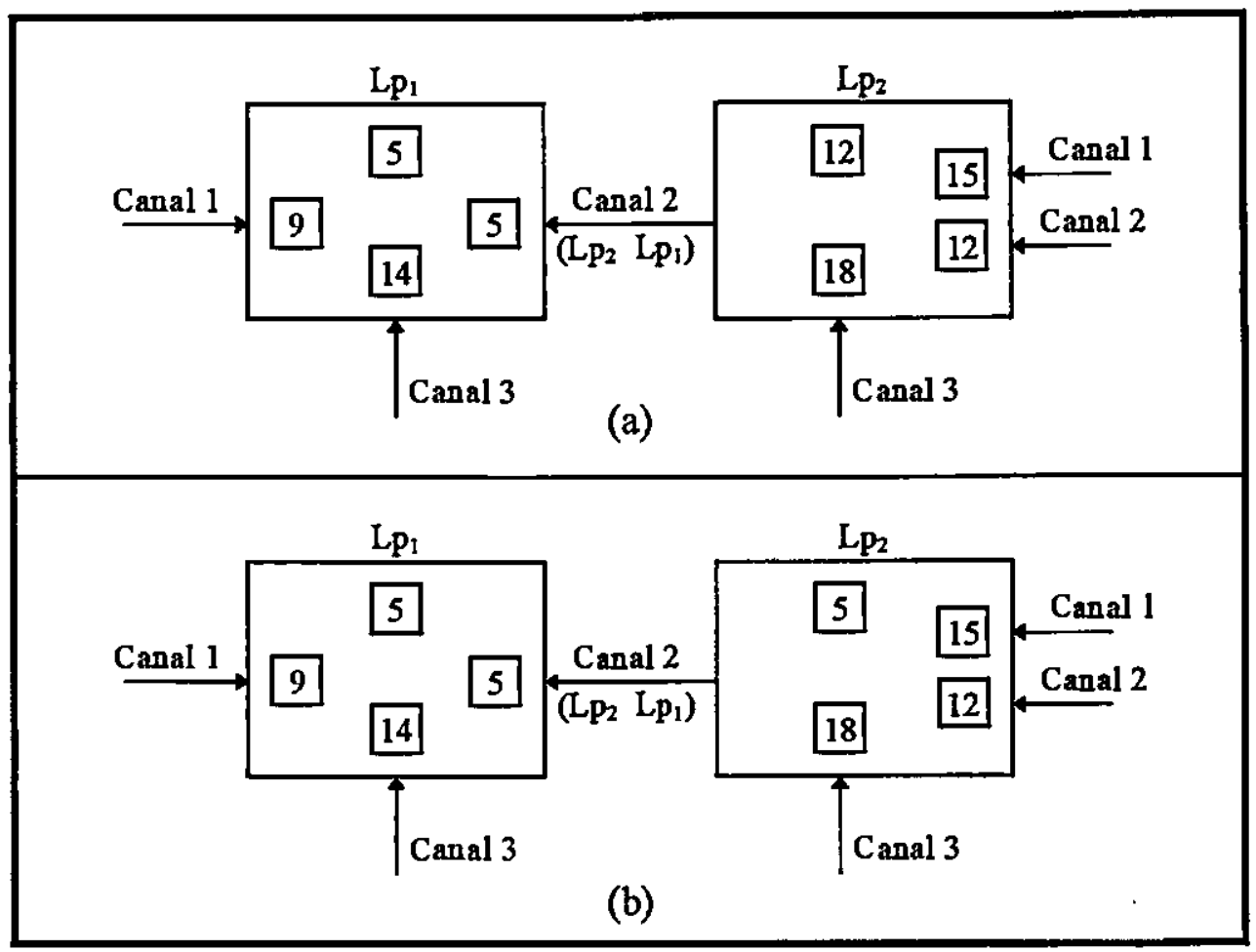

Figura 4.4 - (a) (b) - Transmissão de Mensagens Nulas Sob Demanda

Porém, se o valor do relógio do canal 2 for igual ao valor do LVT de $L p_{2}$, nenhum avanço será possível (figura 4.4 (b)). L p tem que avançar seu próprio LVT primeiro, fazendo o mesmo tipo de pedido a todos os processos que enviam para $\mathrm{Lp}_{2}$, cujos relógios do canal sejam iguais ao LVT de $\mathrm{L}_{2}$. É o caso do canal de entrada 2 do $\mathrm{L}_{\mathrm{p}_{2}}$. Nesse caso, o pedido será efetivamente propagado por Lp2.

-Somènte quảido o valor dó LVT de $\mathrm{L}_{2}$ for maiör que $\sigma$ vator do relógio do canal $2, \mathrm{~L}_{2}$ pode enviar uma mensagem para $L_{p_{1}}$, incrementando o valor do relógio do canal 2 . As propagações dos pedidos de avanço de relógio podem formar um ciclo, gerando uma situação de deadlock. Considere a situação demonstrada na figura 4.5 (Misra, 1986). Uma mensagem solicitando o avanço do relógio é enviada por $\mathrm{Y}$ para $\mathrm{X}$, propagada para $\mathrm{Z}$ e então retorna $\mathrm{Y}$, que detecta o deadlock. Mesmo se a mensagem fosse enviada por $\mathrm{X}$ (enviada a $\mathrm{Z}$ ), e propagada de $\mathrm{Z}$ para $\mathrm{Y}$; $\mathrm{Y}$ responde 
avançando o relógio do canal (Y Z) para 20, Z envia a mensagem novamente para $Y$, Y propaga para $Z$, que detecta então o deadlock.

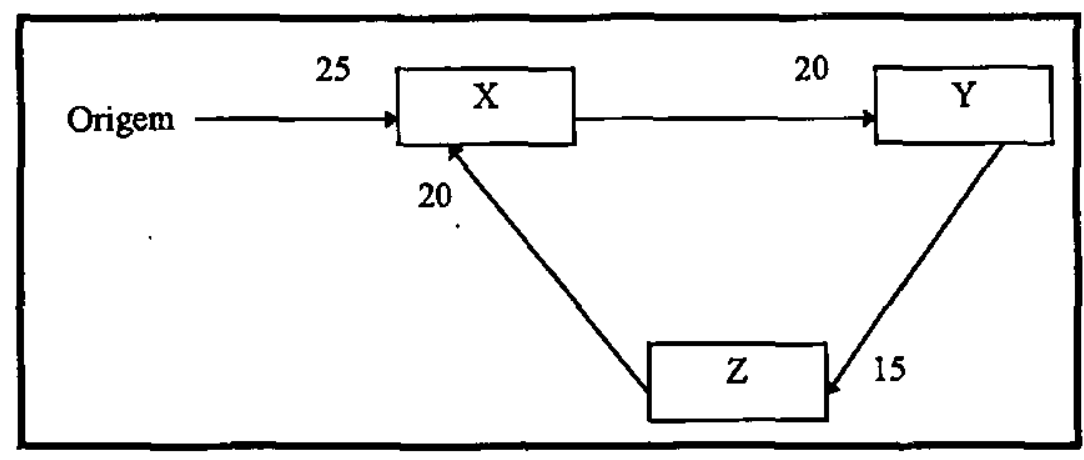

Figura 4.5 - Simulação Distribuída em Deadlock.

Segundo Misra (Misra, 1986), a resolução do deadlock é dificil e pode ser efetuada determinando-se o mínimo dos próximos tempos de eventos: para cada processo no conjunto de processos em deadlock, o tempo em que uma mensagem será enviada (contando que nenhuma mensagem posterior seja recebida até então) é determinado e o valor do relógio do processo com menor relógio é avançado para esse tempo. Esses cálculos podem ser realizados de modo centralizado ou descentralizados.

Uma vantagem desse protocolo é que ele ajuda a reduzir a quantidade de tráfego das mensagens nulas. Uma desvantagem é um atraso maior para receber as mensagens nulas, já que no mínimo duas transmissões de mensagens são necessárias: uma requisitando uma mensagem de avanço de relógio e a própria resposta a esse pedido.

\subsubsection{Deteç̧ão e Recuperação do Deadlock}

Para aplicações onde a ocorrência de deadlock é rara, tem-se uma sobrecarga de envio de mensagens mulas, que na maior parte dos casos é desnecessária (Azevedo, 1993). Para essas aplicações, Chandy e Misra também desenvolveram um protocolo alternativo que elimina o uso de mensagens nulas (Chandy \& Misra, 1981). Nesse protocolo, a simulação é executada até que entre em deadlock. Um mecanismo detecta quando isso ocorre, e outro mecanismo é utilizado para a recuperação de deadlock, para que a simulação prossiga a sua execução. 
Esse protocolo considera um marcador que circula continuamente pela rede, devendo percorrer todos os canais da rede em algum tempo durante o ciclo. Esse marcador é apenas um tipo especial de mensagem. Quando o processo recebe o marcador, deve enviá-lo (para sua rota designada) depois de um certo tempo em que o processo se tornar ocioso, ou seja, sem mensagens para enviar (Misra, 1986)(Fujimoto, 1990).

Cada processo tem um flag de 1 bit que indica se o processo recebeu ou enviou uma mensagem desde a última passagem do marcador pelo processo. Um processo é branco se ele não recebeu nem enviou mensagens desde a última passagem do marcador; caso contrário, o processo é preto. Inicialmente, todos os processos são pretos. A situação de deadlock é detectada quando os $\mathrm{N}$ últimos processos visitados pelo marcador entejam brancos ( $\mathrm{N}$ é o número de canais na rede). Contudo, o sucesso desse protocolo é garantido apenas quando, entre dois processos quaisquer, a ordem de recebimento das mensagens (inclusive o marcador) for a mesma ordem em que foram enviados.

O marcador, além de armazenar o número de processos brancos que visitou desde o último processo preto que viu, contém informações sobre os próximos tempos de eventos dos processos brancos que visitou. Quando o marcador detecta o deadlock, ele possui o próximo tempo de evento e o processo em que o evento ocorre, podendo reiniciar o processo (Misra, 1986). A desvantagem desse protocolo é a sobrecarga de comunicação gerado pela transmissão do marcador.

\subsubsection{Lookahead}

Lookahead não é um mecanismo de simulação distribuída, mas uma técnica fundamental da qual os protocolos conservativos fazem uso. Fujimoto, em (Fujimoto, 1990), demonstra a importância de explorar as características de lookahead para obter um bom desempenho. Dependendo do lookahead, o ganho em termos de velocidade de execução de uma determinada simulação variou de mais lento que a simulação seqüencial para um ganho quase ideal (ganho de $\mathrm{N}$ em $\mathrm{N}$ processadores).

Chandy e Misra (Misra, 1986) definem lookahead como o intervalo de tempo em que um processo pode investigar o futuro com absoluta certeza. Já Fujimoto (Fujimoto, 1990) define lookahead como a capacidade de prever o que acontecerá, ou mais importante, o que não 
acontecerá, no tempo de simulação futuro. Se um processo, no tempo de simulação $T$, pode prever com segurança todos os eventos que ele gerará até o tempo de simulação $T+L$, pode-se dizer que este processo tem lookahead $\mathrm{L}$.

Incrementos mínimos diferentes de zero nos timestamps (dos eventos) são a forma mais evidente de lookahead: um incremento mínimo no timestamp de $L$ representa um lookahead de $L$, pois o processo pode garantir que nenhuma mensagem nova de evento será criada com timestamp menor que $T+L$.

O mecanismo de lookahead aumenta a capacidade de prever eventos seguros, que, por sua vez, pode ser usado para determinar que outros eventos são seguros de se processar. É utilizado principalmente nos seguintes protocolos:

- CMB (Prevenção de Deadlock): para determinar os timestamps das mensagens nulas;

- Deteção e Recuperação de Deadlock: quando um processo envia uma mensagem com um incremento de $L$ no timestamp para outro processo, para garantir que nenhuma outra mensagem que contenha um timestamp menor que $T+L$ seguirá pelo canal (Azevedo, 1993).

Diferentes modelos de simulação apresentam capacidade de lookahead distintos. Por exemplo, em uma simulação de redes de filas $F I F O$, sem preempção e tempo de serviço exponencialmente distribuído. Supondo-se que no tempo 30 o cliente A utiliza o servidor (tempo de serviço igual a 12), e os clientes B, C e D estão na fila aguardando atendimento. No tempo 32 um novo cliente, $\mathrm{E}$, chega com tempo de serviço igual a 9. A tabela 4.1 apresenta os tempos de início e de término para cada cliente no sistema (Preiss \& Loucks, 1990).

\begin{tabular}{|c|c|c|}
\hline Cliente & $\begin{array}{c}\text { Início de } \\
\text { Atendimento }\end{array}$ & $\begin{array}{c}\text { Término de } \\
\text { Atendimento }\end{array}$ \\
\hline A & 30 & 42 \\
\hline B & 42 & 45 \\
\hline C & 45 & 50 \\
\hline D & 50 & 61 \\
\hline E & 61 & 70 \\
\hline
\end{tabular}

Tabela 4.1 - Tempos de Serviço 
As características associadas com lookahead podem ser descritas em termos do comportamento do processo (responsável pela simulação do modelo de filas) quando o cliente $\mathrm{E}$ chega ao sistema. O processo que simula a fila é mostrado na figura 4.6. Depois que o processo completa sua execução no tempo 31, o próximo evento a ser processado é a mensagem do tempo 32 (cliente E). É possivel para o processo calcular o tempo da mensagem de saida (relativa ao cliente E) que tenha um timestamp de 70. Essa estimativa pode mudar se a disciplina da fila não for FCFS ou se houver preempção.

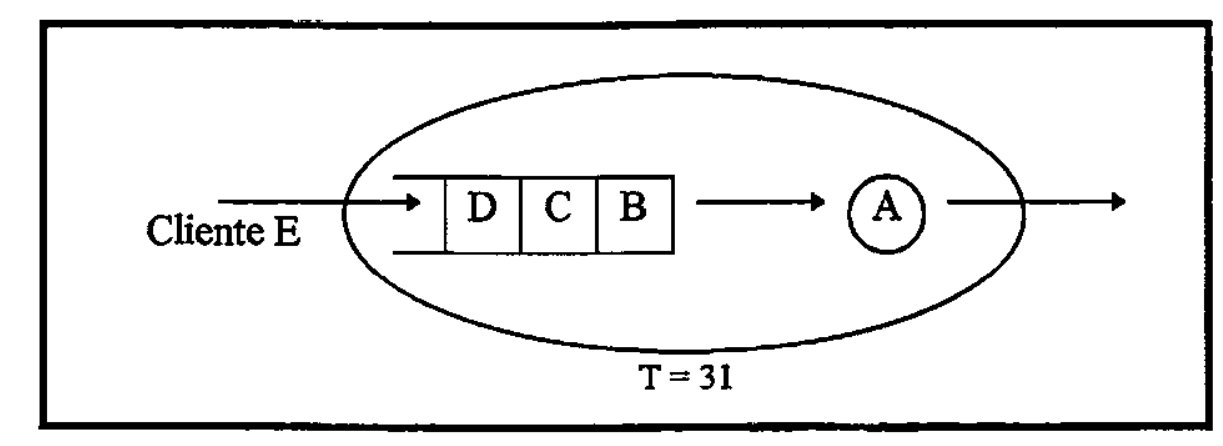

Figura 4.6 - Processo para o Exemplo de Filas

Em uma simulação de redes de filas FIFO, sem preempção, pode-se pré-computar o tempo de serviço das tarefas ainda não recebidas. Se o processo encontra-se ocioso, seu relógio tem valor 100 e o tempo de serviço da próxima tarefa foi pré-computado para ser 50 , então o limite mínimo do timestamp da próxima mensagem a ser enviada é 150 .

\subsection{Considerações Finais}

A simulação distribuída refere-se à execução de um único programa de simulação em um computador paralelo. Essa técnica tem atraído um interesse considerável nos últimos anos. A partir de um ponto de vista pragmático, esse interesse surgiu com o crescimento da utilização da simulação na engenharia, ciệncias de computação, economia e aplicações militares (Morselli, 1995).

A simulação, seqüencial ou distribuída, constitui hoje uma poderosa ferramenta na avaliação de desempenho de sistemas computacionais. O problema é determinar qual abordagem utilizar; se for distribuída, qual protocolo de sincronização escolher, etc.. No capítulo 6 (Plano de Trabalho), é 
apresentada uma tabela que compara algumas características entre o protocolo conservativo CMB e o protocolo otimista Time Warp.

Na simulação distribuída, a desvantagem mais séria dos protocolos conservativos é que esses protocolos não exploram completamente o paralelismo inerente à aplicação que está sendo simulada. Se existe a possibilidade de que um evento $\mathrm{A}$ afete um evento $\mathrm{B}$ direta ou indiretamente, necessariamente os eventos serão executados seqüencialmente. Se A raramente afeta $B$, os eventos poderiam ser executados em paralelo, porém o protocolo se comporta de maneira excessivamente pessimista, forçando uma execução seqüencial quando ela não seria necessária. 


\section{Capítulo 5}

\section{O Protocolo Otimista Time Warp}

Este capitulo descreve o protocolo otimista Time Warp e o paradigma de Tempo Virtual, que foi a base para a confecção do Time Warp. Alguns mecanismos de deteç̧ão e recuperação de erros são abordados, além de algumas técnicas de gerenciamento de memória no Time Warp.

\subsection{Introdução}

Métodos otimistas detectam e recuperam erros de violação de causalidade (Fujimoto, 1990). Ao contrário dos mecanismos conservativos, os métodos otimistas não necessitam determinar quando é seguro processar um evento. Eles executam normalmente até a ocorrência de uma violação de causalidade, invocam um procedimento para a recuperação dessa violação. A abordagem otimista para simulação distribuída, chamada Time Warp, foi proposta por Jefferson (Jefferson, 1985) e baseia-se no paradigma de Tempo Virtual, utilizado para organizar e sincronizar processos em ambientes distribuídos.

o Time Warp emprega dois mecanismos fundamentais de controle: o mecanismo de controle local e o mecanismo de controle global, discutidos nas seções 5.3.1. e 5.3.2, respectivamente.

O mecanismo de sincronização Time Warp solicita mais memória para executar uma simulação distribuída que a equivalente simulação seqüencial, ou a simulação distribuída conservativa. Esse problema requer esquemas sofisticados para gerenciar a memória, alguns desses esquemas são descritos na seção 5.3.4.

\subsection{O Paradigma de Tempo Virtual}

O paradigma de tempo virtual foi proposto por David R. Jefferson, em 1985. O objetivo desse paradigma é organizar e sincronizar os processos em um ambiente distribuído, através do uso 
de um sistema de coordenadas de tempo e espaço virtuais. Esse paradigma é especialmente utilizado em problemas que envolvem sincronismo em simulação distribuída e no controle de concorrência em banco de dados distribuídos (Jefferson, 1985).

Um sistema de tempo virtual é um sistema distribuído, executando em coordenação com um relógio imaginário, que é usado para estimar o progresso computacional e definir a sincronização. Considere, por exemplo, um sistema com muitos processos pequenos, todos executando concorrentemente sobre um computador com vários processadores. Deve-se ressaltar que cada processo ocupa um lugar no espaço virtual, com um nome que deve ser único em todo o sistema, e que atua como sua coordenada espacial. Cada ação primitiva (mudança de variáveis, envio de mensagens, etc.) possui coordenadas de tempo e espaço virtuais. Dessa forma, o conjunto de todas as ações localizado no mesmo espaço virtual $x$ e tempo virtual $t$, refere-se a um evento em $(x, t)$.

Os processos se comunicam apenas por troca de mensagens. Todas as mensagens contêm quatro valores (Jefferson, 1985): o nome do processo transmissor, o tempo virtual de envio, o nome do processo receptor e o tempo virtual de chegada. O tempo virtual de envio é o tempo virtual no momento em que a mensagem é enviada. Da mesma forma, o tempo virtual de chegada de uma mensagem é o tempo virtual em que esta deve ser recebida por um determinado processo. Esses valores são considerados partes da informação contida na mensagem, podendo ser lidos pelo processo receptor.

Os sistemas de tempo virtual baseiam-se em duas regras fundamentais (Jefferson, 1985):

Regra 1. O tempo virtual de envio de uma mensagem deve ser menor que seu tempo virtual de chegada.

Regra 2. O tempo virtual de um evento em um processo deve ser menor que o tempo virtual do próximo evento.

O mecanismo Time Warp (abordado na seção 5.3.) é implementado através do paradigma de tempo virtual. 


\subsection{O Mecanismo Time Warp}

O Time Warp é o protocolo otimista para sincronização de simulação distribuída mais citado na literatura (Fujimoto, 1990)(Jefferson, 1985)(Preiss \& MacIntyre, 1992)(Overeinder et al., 1991). Esse mecanismo não foi projetado para atender a uma arquitetura específica de computadores, podendo ser implementado em sistemas com multiprocessadores, em redes Ethernet, entre outros (Jefferson, 1985).

O Time Warp apresenta dois mecanismos básicos:

- O mecanismo de controle local - cujo objetivo é garantir que os eventos sejam executados e as mensagens recebidas estejam em ordem correta;

- O mecanismo de controle global - destinado ao gerenciamento de memória, controle de fluxo, I/O, tratamento de erros, etc.

\subsubsection{O Mecanismo de Controle Local}

Um processo do protocolo Time Warp estrutura-se da seguinte maneira:

- Relógio local: determina o tempo virtual local (LVT) de um determinado processo. $O$ valor desse relógio não muda durante a ocorrência de um evento, mas sim entre eventos;

- Lista de Entrada de Mensagens: é uma lista para armazenar as mensagens recebidas. As mensagens que já foram processadas situam-se na parte "passada" da lista, e as que ainda não foram processadas situam-se na parte "futura" da lista. Nessa lista, as mensagens são armazenadas em ordem crescente de timestamp, sendo que todas as mensagens devem ter timestamps maiores ou iguais ao LVT;

- Lista de Saída de Mensagens: é uma lista que contém as cópias das mensagens que já foram enviadas para outros processos. Nessa lista, todas as mensagens devem ter timestamps menores ou iguais ao LVT;

- Lista de Estados Passados: cada processo mantém uma lista de estados passados, com timestamps menores que LVT. 
A execução de um processo consiste na recepção de mensagens e execução de eventos, em ordem crescente de timestamp. Essa execução prossegue enquanto nenhuma mensagem chegar com timestamp menor que o de uma mensagem já processada (violação de causalidade). Para ordenar o timestamp, o processo receptor deve efetuar rollback para retornar a um estado anterior à violação. O evento causador de rollback é chamado de extraviador (straggler) (Fujimoto, 1990)(Preiss \& MacIntyre, 1992) (Overeinder et al., 1991). A recuperação é obtida ao se desfazer os efeitos causados por todos os eventos que foram processados prematuramente pelo processo que recebeu o evento extraviador.

Como citado anteriormente, a execução prematura de um evento determina que o estado do processo e as mensagens enviadas para outros processos, ou para ele próprio, durante a vigência da violação, sofram rollback. No mecanismo de rollback, um processo é acompanhado pelo salvamento periódico de seus estados, restaurando um vetor de estados antigos. O cancelamento de uma mensagem previamente enviada ocorre através do envio de uma antimensagem que elimina a mensagem original (Overeinder et al., 1991).

\section{Rollback e Antimensagens}

Para um melhor entendimento do funcionamento da técnica de rollback, considere o exemplo apresentado na figura 5.1. Esse exemplo descreve a estrutura de um processo denominado $X$. Esse processo, em tempo de execução, é composto de (Jefferson, 1985):

- Nome do processo (coordenada de espaço virtual), no caso $X$, o qual deve ser único no sistema;

- Um relógio virtual local ou LVT (coordenada de tempo virtual), no qual está armazenado o valor 162, indicando que a mensagem com o tempo de chegada (timestamp) 162 está sendo processada;

- Um estado representa os dados do processo, como por exemplo, pilha, variáveis e o contador de programa. Esse exemplo utiliza apenas duas variáveis locais (4 e 12) para representar o estado atual do processo $X$; 
- Uma lista de estados passados que contém cópias salvas dos estados mais recentes do processo. Para realizar o rollback, o mecanismo Time Warp deve, periodicamente, salvar os estados do processo;

- Uma lista de entrada de mensagens que contém todas as mensagens recentemente recebidas, organizadas em ordem crescente do tempo de chegada (timestamp). Observe que algumas dessas mensagens já foram processadas, devido aos seus tempos de chegada serem inferiores a 162. Entretanto, elas não são removidas da fila, pois poderão ser necessárias para realizar futuros rollbacks;

- Uma lista de saída de mensagens que contém cópias de mensagens (mensagens negativas) já enviadas pelo processo para outros processos do sistema. Essas mensagens são organizadas em ordem crescente do tempo virtual de envio. 
\begin{tabular}{|}
\hline \begin{tabular}{|c|c|}
\hline Estado Atual \\
\hline 4 & 12 \\
\hline
\end{tabular}
\end{tabular}

Processo X

Tempo Virtual Local - LVT

162 Lista de Entrada de Mensagens

\begin{tabular}{|c|c|c|c|c|c|c|c|l|}
\hline 110 & 105 & 120 & 125 & 130 & 146 & 175 & 176 & Tempo de Envio \\
\hline 112 & 119 & 121 & 141 & 156 & 162 & 181 & 182 & Tempo de Chegada \\
\hline
\end{tabular}

\begin{tabular}{|l|l|l|l|l|l|l|l|} 
E & C & B & E & B & D & B & B \\
\hline
\end{tabular}

\begin{tabular}{l|l|l|l|l|l|l|l|l} 
A & A & A & A & A & A & A & A \\
\hline
\end{tabular}

\begin{tabular}{|l|l|l|l|l|l|l|l|l|}
+ & + & + & + & + & + & + & + & Sinal \\
\hline & & & & & & & &
\end{tabular}

Lista de Saída de Mensagens

\begin{tabular}{|c|c|c|c|c|c|c|c|}
\hline 119 & 121 & 141 & 141 & 156 & 156 & 162 & Tempo de Envio \\
\hline 141 & 122 & 142 & 196 & 180 & 157 & 163 & Tempo de Chegada \\
\hline A & A & A & $\mathrm{A}$ & A & A & A & Processo Transmissor \\
\hline A & B & B & $\mathrm{C}$ & $\mathrm{C}$ & $\mathrm{D}$ & $\mathrm{C}$ & Processo Receptor \\
\hline- & - & - & - & - & - & - & Sinal \\
\hline & & & & & & & Texto \\
\hline
\end{tabular}

Lista de Estados Passados

\begin{tabular}{|c|c|c|c|c|c|c|c|c|c|c|}
\hline \multicolumn{2}{|c|}{82} & \multicolumn{2}{|c|}{90} & \multicolumn{2}{|c|}{106} & \multicolumn{2}{|c|}{119} & \multicolumn{2}{|c|}{141} & \\
\hline 3 & 12 & 7 & 12 & -2 & 12 & 8 & 12 & 0 & 12 & Estados Salvos \\
\hline
\end{tabular}

Figura 5.1 - Um Processo Time Warp 
Para cada mensagem existe uma antimensagem, que é exatamente igual em formato e conteúdo da mensagem original, exceto por um campo - seu sinal. Todas mensagens enviadas explicitamente por processos têm um sinal positivo $(+)$ e suas antimensagens têm um sinal negativo (-) (Jefferson, 1985). Sempre que um processo envia uma mensagem, essa mensagem é transmitida para lista de entrada do processo receptor e uma cópia negativa dessa mensagem, a antimensagem, é mantida na lista de saída do processo transmissor, para uso posterior, no caso desse processo realizar rollback.

A manipulação de mensagens negativas é similar às 'mensagens positivas. Sempre que uma mensagem positiva e sua antimensagem ocorrem na mesma lista, elas imediatamente se eliminam. Em geral, mensagens e antimensagens são criadas em pares e eliminadas em pares.

Quando uma mensagem chega na lista de entrada de um processo com um timestamp maior que o LVT desse processo, ela é simplesmente enfileirada, e esse processo continua sua execução normalmente. Caso contrário, considere que uma mensagem com o tempo de chegada 135 atinge o processo $X$, cujo LVT possui o valor 162 , como ilustrado na figura 5.2. Esse fato indica que o trabalho realizado por esse processo desde o tempo virtual 135 pode estar incorreto e deve ser desfeito através de rollback.

O primeiro passo no mecanismo rollback é procurar a lista de estados passados que contém o último estado do processo $X$, salvo antes do tempo 135 . O valor 135 é também usado para atualizar o valor do LVT de $X$. Depois disso, todos os estados armazenados na lista de estados passados após o tempo 135 são descartados e o processo $X$ é novamente reativado (Jefferson, 1985).

Deve-se ainda corrigir os efeitos causados entre os tempos 135 e 162, onde várias mensagens enviadas pelo processo $X$ para outros processos devem ser canceladas. Para isso, o processo $\mathrm{X}$ transmite as mensagens negativas (antimensagens).

O mecanismo Time Warp transmite para os processos receptores todas as mensagens contidas na lista de saída do processo $X$, que estão situadas nos tempos virtuais de envio entre 135 e 162 , deixando o processo $X$ com nenhum registro que uma dessas mensagens já existiu. No final, o processo $X$ e todas suas listas ficam no estado em que deveriam estar se a mensagem com timestamp 135 tivesse chegado em ordem correta. 


\section{Estado Atual}

\begin{tabular}{|l|l|}
\hline 5 & 12 \\
\hline
\end{tabular}

\section{Processo X}

\begin{tabular}{|c|c|c|c|c|c|c|c|c|c|c|}
\hline 135 & Lista & le Entr & ada de & Mens & gens & & & & & \\
\hline & 110 & 105 & 120 & 132 & 125 & 130 & 146 & 175 & 176 & Tempo de Envio \\
\hline & 112 & 119 & 121 & 135 & 141 & 156 & 162 & 181 & 182 & Tempo de Chegada \\
\hline & $E$ & $\mathrm{C}$ & B & $\mathrm{E}$ & $\mathrm{E}$ & B & $\mathrm{D}$ & B & B & Processo Transmissor \\
\hline & A & A & $\mathrm{A}$ & $\mathrm{A}$ & A & A & A & A & A & Processo Receptor \\
\hline & + & + & + & + & + & + & + & + & + & Sinal \\
\hline & & & & & & & & & & Texto \\
\hline
\end{tabular}

Lista de Saída de Mensagens

\begin{tabular}{|c|c|l|l}
\hline 119 & 121 & Tempo de Envio \\
\cline { 1 - 2 } 141 & 122 & Tempo de Chegada \\
\cline { 1 - 2 } A & A & Processo Transmissor \\
\cline { 1 - 2 } A & B & Processo Receptor \\
\cline { 1 - 2 }- & - & Sinal \\
\hline & & Texto \\
\hline
\end{tabular}

Lista de Estados Passados

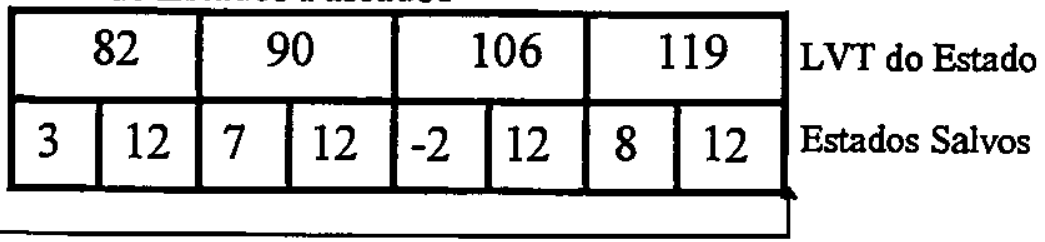

Figura 5.2 - Rollback para o tempo 135. 
O recebimento de uma mensagem negativa pode causar rollback se o seu tempo virtual de chegada (timestamp) for menor que o LVT do receptor (tal como uma mensagem positiva faria). Dependendo do momento em que a mensagem negativa chega ao processo destino, diferentes atitudes podem ser consideradas para a realização ou não de rollback (Jefferson, 1985):

- Se a mensagem original (positiva) já chegou, mas ainda não foi processada, seu timestamp deve ser maior que o LVT do processo receptor. A mensagem negativa, que tem o mesmo tempo virtual de chegada, será colocada na mesma lista de entrada e não ocorrerá rollback. Entretanto, elas se eliminarão, deixando o processo receptor com nenhum registro que essas mensagens existiram.

- Se a mensagem original (positiva) possui um timestamp igual ou menor ao LVT do processo receptor, ela (e talvez outras mensagens) pode já ter sido parcialmente ou completamente processada, causando efeitos adversos no estado do processo receptor, possibilitando o envio de mais mensagens para um terceiro conjunto de processos. Nesse caso, a mensagem negativa também chegará atrasada e causará rollback para o tempo virtual de quando a mensagem positiva foi recebida. A mensagem original será eliminada pela sua antimensagem. No entanto, ao reiniciar sua execução, esse processo deve enviar outras antimensagens (rollbacks secundários) àquele terceiro conjunto de processos, com o objetivo de eliminar as mensagens enviadas durante a ocorrência da violação de causalidade.

- Se uma mensagem negativa chegar antes da positiva, a mensagem negativa é armazenada na lista de entrada de mensagens até a chegada da mensagem positiva. Quando a mensagem positiva chegar no processo destino ela também é inserida na lista de entrada de mensagens, ocasionando a eliminação das mensagens positivas e negativas.

Segundo Jefferson (Jefferson, 1985), o protocolo de antimensagens é bastante robusto. O processo de rollback não necessita ser atômico, permitindo que muitos rollbacks sejam realizados simultaneamente. Não existe possibilidade de deadlock no time warp, por ele ser não bloqueante.

Com o rollback, cada processo deve periodicamente salvar (parte ou completamente) seu estado, esse salvamento é referido na literatura como ponto de checagem - checkpointing. $O$ ponto de checagem pode gerar dois efeitos adversos à simulação: (1) sobrecarga de memória consumida, 
pois é possível que não haja memória suficiente para realizar a simulação por completo, e (2) o tempo de processamento necessário para copiar a porção do estado no ponto de checagem pode vir a comprometer a realização da simulação(Preiss \& MacIntyre, 1992).

\subsubsection{O Mecanismo de Controle Global}

No Time Warp, o mecanismo de controle local não consegue resolver questões relacionadas ao sistema global. Algumas questões, tais como: É possivel assegurar o progresso global do sistema, entre tantas ativadades de rollback? Como é possivel manipular E/S com o rollback? entre outros. $\mathrm{O}$ mecanismo de controle global trabalha para manipular e solucionar todas essas questões (Jefferson, 1985).

O principal conceito dentro do mecanismo de controle global é o do tempo virtual global ou GVT (Global Virtual Time). O GVT é uma foto instantânea e global do sistema em um tempo $r$, sendo definido como (Jefferson, 1985)(Preiss \& MacIntyre, 1992)(Fujimoto, 1990)(Overeinder et al., 1991)(Das \& Fujimoto, 1993):

“GVT é o menor entre: (1) os LVT's de todos os processos, e (2) o tempo virtual de envio de todas mensagens, incluindo àquelas que estão em trânsito ou situadas na parte futura da lista de entrada (mensagens ainda não processadas) do processo receptor".

GVT é considerado o relógio virtual do sistema e é utilizado como valor base do sistema, pois nenhum evento com tempo menor que o GVT pode sofrer rollback. A figura 5.3 ilustra a relação entre o GVT e o LVT (Preiss \& Loucks, 1995).

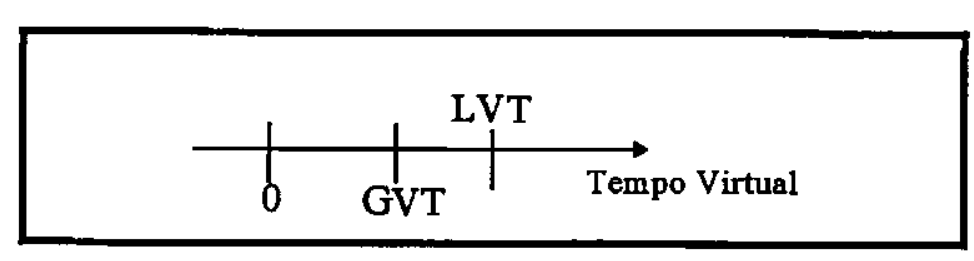

Figura 5.3 - Relação entre os Valores do Tempo de Simulação.

O LVT é o tempo virtual local corrente do processo. Se a simulação fosse parada, os LVT's de todos os processos do sistema seriam verificados juntamente com os tempos virtuais de envio de 
todas mensagens em trânsito, ou situadas na parte futura da lista de entrada, a fim de se realizar o cálculo do GVT.

\subsubsection{Uso de GVT para Gerenciamento de Memória e Controle de Fluxo}

No Time Warp, em adição à memória usada para codificar e processar os dados correntes, existem quatro tipos adicionais de sobrecarga de memória a serem gerenciados (Jefferson, 1985):

- Estados passados em uma lista de estados;

- Mensagens armazenadas em listas de saída;

- Mensagens "passadas" (na lista de entrada) que já foram processadas;

- Mensagens "futuras" (na lista de entrada) que ainda não foram processadas.

As três primeiras classes de armazenamento, usadas apenas para suportar rollback, são similarmente gerenciadas. Qualquer mensagem contida em uma lista de entrada ou saída, cujo timestamp for menor que GVT, pode ser descartada. Igualmente, cada estado salvo de um processo com tempo anterior ao GVT, também pode ser descartado. Geralmente, o processo de destruição de informações com tempos mais antigos que o GVT é referido como coleta de fósseis (Jefferson, 1985)(Fujimoto, 1990) (Preiss \& MacIntyre, 1992).

Gerenciar a quarta classe de armazenamento, que contém mensagens não processadas (às vezes, essas mensagens ainda não foram efetivamente recebidas), faz parte do problema de controle de fluxo em ambientes distribuídos. Na maioria desses ambientes, a única ferramenta de sincronização é o bloqueio de processo. Protocolos de controle de fluxo atuam como válvulas limitadoras do fluxo de mensagens do processo transmissor para o processo receptor. $O$ processo receptor deve ser cuidadoso para não aceitar muitas mensagens, pois ele torna-se responsável pelo armazenamento, em um buffer, das mensagens recebidas até que sejam processadas e armazenadas (Jefferson, 1985).

Se a memória do processo receptor encontra-se cheia de mensagens, o mecanismo Time Warp deve ser capaz de recuperar espaço através do devolvimento de mensagens ainda não processadas para o(s) seu(s) respectivo(s) processo(s) transmissor(es). O processo transmissor deve efetuar rollback para o estado em que se encontrava quando enviou a mensagem e, posteriormente, 
transmitir novamente a mensagem para que seja executada pelo processo destino (Jefferson, 1985)(Steinman et al., 1995).

\subsubsection{Entrada e Saída}

Quando um processo envia um comando para um dispositivo de saída, ou qualquer outro agente externo, torna-se necessário que nenhuma atividade física de saída seja realizada imediatamente, porque o processo transmissor pode realizar rollback e cancelar a requisição de saída. A saída só pode ser fisicamente efetuada se o GVT for maior que o timestamp da mensagem que contém o comando. Depois desse ponto, nenhuma antimensagem para o comando pode ser gerada e a saída pode ser realizada seguramente, em ordem de timestamp.

\subsubsection{Estratégias de Cancelamento}

Quando ocorre rollback, algumas mensagens enviadas para outros processos podem necessitar ser canceladas. Existem três estratégias de cancelamento no Time Warp: Agressiva, Preguiçosa (Lomow et al., 1988)(Reiher et al., 1990)(Preiss \& MacIntyre, 1992) e Direta (Fujimoto, 1990).

Cancelamento Agressivo: quando essa estratégia de cancelamento é utilizada, antimensagens são enviadas imediatamente após à ocorrência de violações de causalidade. Tais mensagens freqüentemente ocasionam rollbacks secundários, podendo gerar cascatas de rollbacks, em outros processos. Nesse tipo de cancelamento, as mensagens canceladas podem produzir erros computacionais em outros processos.

Cancelamento Preguicoso: quando essa estratégia de cancelamento é adotada, as antimensagens não são enviadas imediatamente após à ocorrência de violações de causalidade. Ao invés disso, elas ficam observando se a reexecução da computação regenera as mesmas mensagens; se as mesmas mensagens são criadas, em ordem correta de timestamps, não há necessidade de se cancelar as mensagens originais via antimensagens.

Uma antimensagem, criada em tempo de simulação $T$, é enviada apenas se o relógio do processo ultrapassa esse tempo $T$, sem regenerar a mesma mensagem original. Esse tipo de 
cancelamento pode reduzir a quantidade de rollbacks secundários, em relação ao cancelamento agressivo.

Dependendo do tipo da aplicação, cancelamento preguiçoso pode melhorar ou degradar o desempenho do sistema que está sendo simulado. Evidências empiricas sugerem que, na prática, 0 cancelamento preguiçoso desempenha tão bem quanto, ou melhor que, o cancelamento agressivo.

Cancelamento Direto: Essa estratégia de cancelamento, proposta por Fujimoto (Fujimoto, 1989), é utilizada em arquiteturas com memória compartilhada, e tem como objetivo otimizar o cancelamento de computações incorretas através da utilização de ponteiros. Por exemplo, se um evento $E_{1}$ escalona outro evento $E_{2}$, um ponteiro é utilizado para estabelecer a ligação entre $E_{1}$ e $E_{2}$. Entretanto, se ocorrer algum erro no evento $E_{2}$, o ponteiro é usado para cancelar o evento $E_{2}$.

As vantagens apresentadas por essa estratégia são (Fujimoto, 1990): a redução de sobrecarga (de espaço e tempo) associada ao cancelamento de mensagens, e minimização dos danos causados por uma computação errada. Bons desempenhos têm sido registrados na versão do Time Warp que usa cancelamento direto.

\subsubsection{Gerenciamento de Memória}

O mecanismo de sincronização Time Warp requer mais memória para completar uma simulação distribuída que a equivalente simulação seqüencial. Isso acontece porque os programas de simulação seqüenciais requisitam memória apenas para manipular eventos pendentes (da lista de eventos futuros) e uma única cópia do estado do vetor do simulador. O Time Warp, entretanto, faz uso do mecanismo de rollback para sincronizar os diversos processos de um sistema. Esse mecanismo introduz sobrecarga sobretudo no gerenciamento de memória (Das \& Fujimoto, 1993).

Por esse motivo, vários esquemas de gerenciamento de memória têm sido propostos. Alguns deles reduzem a média da utilização do espaço, entretanto, não podem ser utilizados para recuperar espaços de armazenamento de estado. Outros são mais adaptáveis, podendo executar a simulação com a memória disponível (desde que haja uma quantidade mínima de memória disponível, às vezes, 
a utilizada para executar a simulação seqüencial equivalente), e são capazes de recuperar memória "sob demanda ${ }^{14 "}$ (Das \& Fujimoto, 1993)(Preiss \& Loucks, 1995).

A definição operacional do tempo virtual global ou GVT (seção 5.3.2) é importante em vários esquemas de gerenciamento de memória.

O Time Warp consome memória através do armazenamento de três tipos de elementos (Preiss \& Loucks, 1995):

- Armazenamento de Estado: usado para armazenar alguns ou todos os estados (ou vetores de estados), requisitados por um processo durante sua execução;

- Armazenamento de Mensagens em Listas de Entrada: usado para armazenar as mensagens recebidas por um processo receptor;

- Armazenamento de Mensagem em Listas de Saída: usado para armazenar cópias de mensagens enviadas por um processo transmissor.

Podem-se classificar os esquemas de gerenciamento de memória no Time Warp em dois tipos (Das \& Fujimoto, 1993): (1) esquemas que reduzem a média de memória utilizada, mas não recuperam memória "sob demanda", e (2) esquemas que recuperam memória "sob demanda".

\subsubsection{Esquemas que Reduzem a Média de Memória Utilizada}

Embora esses esquemas não sejam forte o bastante para recuperar memória "sob demanda", eles são úteis na redução da média de memória requisitada por programas Time Warp. Alguns esquemas de redução da média de memória utilizada são (Das \& Fujimoto, 1993):

- Redução dos Estados Salvos: quando o tamanho do estado é grande, e apenas uma pequena porção do estado é modificada por um evento, somente a mudança é registrada, ao invés de se fazer uma cópia inteira do estado. Isso reduz o espaço usado e o tempo utilizado que seria necessário para realizar a cópia completa do estado.

- Otimismo Limitado: Diferentes variações do protocolo Time Warp têm sido sugeridas na literatura, com o intuito de limitar a quantidade de processos que possam adiantar-se em relação aos outros, ou seja, que possam provocar violação de causalidade. Alguns desses

\footnotetext{
${ }^{14}$ Segundo Preiss (Preiss \& Loucks, 1995), recuperar memória "sob demanda" significa liberar espaço de memória através do mecanismo de rollback em um ou mais processos lógicos, para um tempo anterior ao tempo de simulação.
} 
limites fazem uso de processos com o protocolo de janela de tempo ${ }^{15}$ (Reiher et al., 1989)(Sokol et al., 1988), alguns tentam controlar a expansão de erros computacionais o mais rápido possível (ver (Madiseti et al., 1988)(Prakash \& Subramarian, 1991)). Outros, porém, limitam o otimismo através do rollingback de todos processos para um ponto próximo do GVT, em intervalos de tempo escolhidos probabilisticamente (Madiseti et al., 1992). Esses esquemas foram sugeridos primeiramente para reduzir a quantidade de rollbacks, entretanto, eles implicitamente reduzem a memória usada através da limitação do número de objetos "futuros".

\subsubsection{Esquemas que Recuperam Memória "Sob Demanda"}

Os esquemas que recuperam memória sob demanda podem ser classificados em duas subclasses: (1) esquemas que recuperam espaços usados por objetos "passados" e (2) esquemas que recuperam espaços usados por objetos "futuros" (Das \& Fujimoto, 1993). Alguns desses esquemas são descritos a seguir.

\section{Esquema que Recupera Espaços Usados por Objetos "Passados"}

- Coleta de Fósseis: Coleta de fósseis (seção 5.3.2.1) recupera os espaços empregados por objetos "passados". A coleta de fósseis é um esquema de gerenciamento de memória bastante difundido, sendo que a maioria dos outros esquemas trabalha em parceria com ele.

\section{Esquemas que Recuperam Espaços Usados por Objetos "Futuros"}

- Retorno de Mensagens: esse protocolo foi proposto por Jefferson, em (Jefferson, 1990). Quando uma mensagem chega em uma lista de entrada de um processo receptor, e não

\footnotetext{
${ }^{15}$ Nesse protocolo, um mestre controla todo o sistema de simulação e os processos são autorizados, por esse mestre, a
} 
existe lugar na lista para armazená-la, o processo receptor devolve uma das mensagens contida nessa lista para o processo que a transmitiu. $O$ processo transmissor (da mensagem original) efetua um rollback para o estado em que se encontrava, no momento do envio da mensagem original, para depois enviá-la novamente para o processo receptor a fim de que seja executada. A mensagem que deve ser devolvida é aquela que possui o maior tempo de envio.

- Protocolo de Gafni - Uma Generalização do Retorno de Mensagens: o retorno de mensagens para o processo transmissor foi, inicialmente, proposto como política de controle de fluxo. O protocolo de Gafni generaliza o retorno de mensagens através da remoção de objetos armazenados (mensagens de entrada, vetores de estado ou mensagens de saída) em um processo $P$. Se o objeto descartado é uma mensagem em uma lista de entrada, ela é devolvida para o seu processo transmissor, como o esquema de Retorno de Mensagens realiza. Se é uma mensagem contida em uma lista de saída, esta é transmitida para o seu processo receptor, onde cancelará a mensagem positiva correspondente, e o processo $P$ aciona o mecanismo de rollback para o estado anterior ao envio da mensagem positiva. Se o objeto armazenado é um estado, ele é descartado e o processo $P$ efetua o rollback para restaurar o estado anterior à violação de causalidade (Das \& Fujimoto, 1993).

- Cancelback: Jefferson em (Jefferson, 1990) propôs o protocolo cancelback destinado às arquiteturas com memória compartilhada, onde existe apenas um pool de memória compartilhada. Todos os processos alocam objetos desse pool de memória compartilhada e liberam esses objetos para o pool, depois de utilizá-los. O protocolo cancelback assume a definição original do GVT. Ele seleciona qualquer objeto "futuro" do sistema, isto é, qualquer objeto que tem seu tempo de envio e timestamp maiores que GVT, para então cancelá-lo. Segundo Jefferson (Jefferson, 1990), o Time Warp com cancelback pode realizar simulação usando nenhum espaço de memória adicional ao correspondente simulador seqüencial; tornando assim o protocolo cancelback um otimizador em 
armazenamento. Um modelo analítico para prognosticar o desempenho do Time Warp com cancelback sobre memória limitada é descrito em (Akyildiz et al., 1992).

\subsection{Considerações Finais}

Os métodos otimistas detectam e solucionam o problema de sincronização entre processos em um ambiente distribuído ou em uma máquina paralela. Ao detectar a violação de relação de causalidade, o processo onde se deu a ocorrência do erro efetua o mecanismo de rollback para retorna ao estado correto anterior ao erro.

As desvantagens do mecanismo Time Warp são a sobrecarga de memória e a comunicação gerada pelo mecanismo de rollback, o que implica em perda de desempenho. Por essas razões, várias técnicas para gerenciar a memória e melhorar o desempenho têm sido propostas.

As duas classes de protocolos disponíveis para sincronização em simulação distribuida, os conservativos (abordados no capítulo 4) e os otimistas apresentam vantagens e desvantagens. A opção entre qual protocolo utilizar não é simples e depende, principalmente, das características da aplicação. 


\section{Capítulo 6}

\section{Projeto e Implementação do Sistema Time Warp (STW)}

Este capitulo descreve o Sistema Time Warp (STW). A estrutura geral desse sistema é apresentada, juntamente com os mecanismos de rollback e antimensagens. As estratégias de Cancelamento Agressivo e Cancelamento Preguiçoso, juntamente com as principais classes que compõem o STW, também são abordados neste capítulo.

\subsection{Considerações Iniciais}

O sistema Time Warp foi desenvolvido neste projeto, e apresenta-se como um sistema composto por um conjunto de programas escrito na linguagem orientada a objetos $\mathrm{CH}$. Seu projeto e implementação se basearam na abordagem otimista Time Warp. O STW procura ser fiel às propostas de Jefferson (Jefferson, 1985), que idealizou o paradigma de tempo virtual, e que serviu de alicerce à concepção do mecanismo Time Warp, idealizado pelo próprio Jefferson. No início deste capítulo é apresentada uma visão comportamental do STW, descrevendo-se os elementos que compõem o sistema e suas interações. Apresenta-se, também, uma visão evolutiva do sistema, a partir de ocorrências de eventos, em tempos discretos, e quando essas ocorrências levam a algumas situações de não sincronismo entre os processos. O mecanismo de rollback e as estratégias de cancelamento - Cancelamento Agressivo e Cancelamento Preguiçoso, utilizados para a recuperação do sincronismo entre os processos e para a eliminação de mensagens enviadas para outros processos no tempo errado, respectivamente, também são abordados neste capítulo.

Visando determinar uma visão mais abrangente da funcionalidade do STW, foram elaborados dois modelos de Rede de Petri para o sistema (seção 6.2.3). Um desses modelos descreve o funcionamento do STW utilizando a estratégia de cancelamento agressivo. O outro descreve o funcionamento do STW usando a estratégia de cancelamento preguiçoso. No final deste capítulo (seção 6.4) são apresentadas as principais classes que constituem o STW. 


\subsection{Estrutura Geral do Sistema Time Warp (STW)}

Em simulação orientada a eventos, um evento ocorre em pontos discretos no tempo, ocasionando a mudança de estado do sistema. Com isso, um sistema que está sendo modelado somente muda seus estados em pontos discretos no tempo simulado através da ocorrência de eventos (Fujimoto, 90). Na simulação seqüencial orientada a eventos, esses eventos são armazenados em uma lista global de eventos, chamada lista de eventos futuros, e o progresso da simulação é monitorado por um relógio global. Mas, devido ao fato da simulação ser atrelada a uma única lista de eventos, a sua execução pode demandar um excessivo esforço computacional, o que pode vir a inviabilizar o processamento dessa simulação. Como alternativa a essa situação, tem-se adotado a solução pela simulação distribuída. No contexto deste trabalho, simular de maneira distribuída implica em particionar o sistema simulado em um conjunto de subsistemas que interagem entre si através da troca de mensagens. $O$ conjunto de subsistemas é simulado por um conjunto de processos lógicos. Cada processo lógico pode armazenar um ou mais objetos. A comunicação entre processos lógicos é realizada através do envio e/ou recebimento de mensagens. Já a comunicação entre objetos situados no mesmo processo lógico é executada através da inserção direta de um evento parametrizado $^{1}$ na lista de entrada do próprio processo lógico. A partir da troca de mensagens ${ }^{2}$, pode-se realizar a sincronização entre os processos envolvidos em uma execução de determinada tarefa.

O STW é um sistema voltado à simulação distribuída orientada a eventos. A lista global de eventos e o relógio global, ambos partes essenciais da simulação seqüencial, não fazem parte desse contexto. Nele, cada processo lógico possui um nome, o qual deve ser único em todo o sistema, uma lista de entrada de eventos ${ }^{3}$, onde são armazenadas os eventos que chegam ao processo, um relógio local (LVT), uma lista que armazena as informações dos estados já ocorridos, uma lista que armazena as cópias dos eventos enviados a si próprio ou a outros processos, além de poder se

\footnotetext{
${ }^{1}$ Neste trabalho, evento parametrizado representa a comunicação entre objetos localizados no mesmo processo lógico. Os campos que fazem parte de um evento são: tempo de envio, tempo de chegada (timestamp), identificador do objeto transmissor, identificador do objeto receptor, sinal e tamanho do evento.

${ }^{t}$ Neste trabalho, mensagem representa a comunicação entre processos lógicos. É composta pelos mesmos campos que fazem parte de um evento parametrizado, acrescentado os campos: identificador do processo lógico transmissor e identificador do processo lógico receptor.

${ }^{3}$ Neste trabalho, lista de entrada de eventos e lista de saida de eventos também se referem à lista de entrada e à lista de saida de mensagens de um determinado processo lógico.
} 
comunicar com os demais processos lógicos do sistema através da troca de mensagens. A lista de entrada de eventos é ordenada de forma ascendente de timestamp, que é o tempo de chegada do evento ao processo lógico receptor, a lista de saída de eventos é ordenada pelo tempo de envio e a lista de estados do processo lógico é ordenada pelo tempo virtual local (LVT). Os elementos que compõem um processo STW estão resumidamente apresentados na tabela 6.1.

\begin{tabular}{|l|l|}
\hline - Nome do Processo & Deve ser único em todo o sistema. \\
\hline $\begin{array}{l}\text { - Virtual Local Time (LVT) } \\
\text { - Tempo Virtual Local }\end{array}$ & $\begin{array}{l}\text { Tempo de chegada (timestamp) do evento que está sendo } \\
\text { processado. }\end{array}$ \\
\hline - Estado Atual & A informação corrente do processo. \\
\hline - Lista de Estados & $\begin{array}{l}\text { Contém cópias dos estados do processo. Com a finalidade de realizar } \\
\text { rollback, deve-se salvar o estado do processo periodicamente. }\end{array}$ \\
\hline - Lista de Entrada & $\begin{array}{l}\text { Contém os eventos/mensagens que chegaram ao processo mais } \\
\text { recentemente. É ordenada pelo timestamp. }\end{array}$ \\
& $\begin{array}{l}\text { Contém uma cópias dos eventos/mensagens que o processo } \\
\text { recentemente enviou a outros objetos ou processos. É ordenada pelo } \\
\text { tempo de envio. É necessária no caso de um eventual rollback, a fim } \\
\text { de cancelar mensagens já enviadas }\end{array}$ \\
\hline
\end{tabular}

Tabela 6.1. Elementos que compõem um processo STW.

A figura 6.1 apresenta graficamente a interação entre três objetos. Os objetos $\mathrm{O}_{1}$ e $\mathrm{O}_{2}$ estão localizados nọ processo lógico 1 e se comunicam através da inserção direta de eventos na lista de entrada do objeto receptor. Quando o objeto $\mathrm{O}_{1}$ ou o objeto $\mathrm{O}_{2}$ deseja estabelecer comunicação com o objeto $\mathrm{O}_{3}$, armazenado no processo lógico 2 , essa comunicação é realizada através da troca de mensagens. Cada evento possui seis parâmetros básicos: tempo de envio, tempo de chegada, identificador do objeto transmissor, identificador do objeto receptor, sinal e tamanho do evento (conforme exposto mais detalhadamente no capítulo 5). Essa figura considera os seguintes fatores: 1) Eventos acontecem em pontos discretos no tempo de simulação; 2) A lista de entrada é ordenada por timestamp; 3) A lista de saída é ordenada pelo tempo de envio; 4) 0 relógio local (LVT) é igual ao timestamp do último evento executado; 5) Execução de evento implica em remover o evento da 
lista de entrada, mudar o estado local do processo lógico, avançar o relógio e possibilitar a geração de novos eventos; 6) Cada processo lógico opera como um simulador independente.

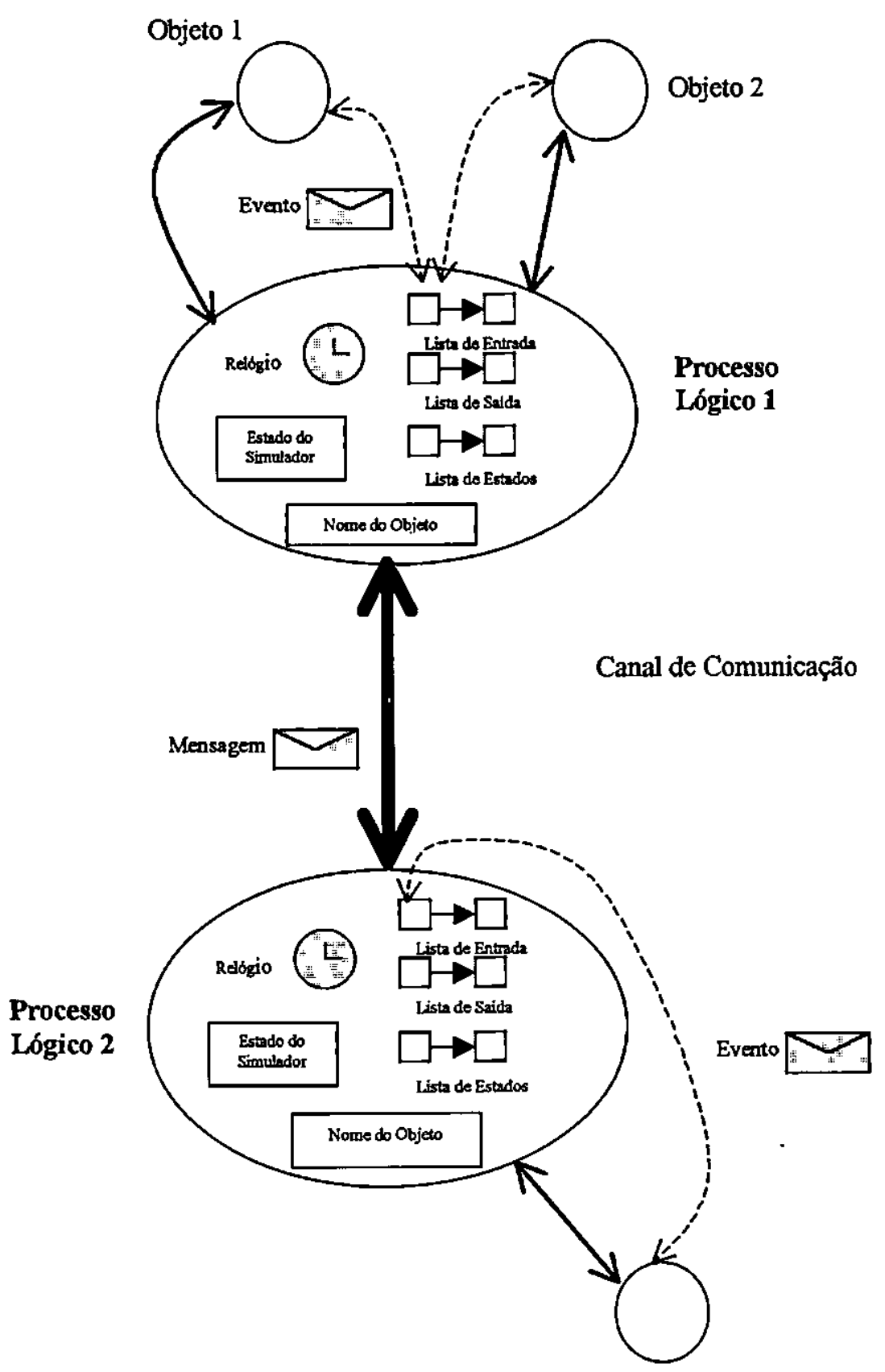

Objeto 3

Figura 6.1. Diagrama estrutural do STW.

Na figura 6.1, cada elipse representa um processo (simulador) que se comunica (seta) com os demais processos lógicos do sistema através da troca de mensagens. Em cada processo, têm-se um 
nome, um relógio local, seu estado atual, uma lista de entradas de eventos, uma lista de saída de eventos e uma lista de estados já ocorridos. Os objetos são representados por círculos e se comunicam com outros objetos armazenados no mesmo processo lógico através da inserção direta de eventos na lista de entrada do processo. Se a comunicação for realizada entre objetos localizados em processos lógicos distintos, faz-se uso do ambiente de passagem de mensagens PVM, a fim de viabilizar a troca de mensagens.

O paralelismo, no STW, encontra-se no nível do processo lógico. Cada processo lógico é responsável pelo gerenciamento de GVT, gerenciamento da comunicação e escalonamento de eventos a serem executados. Os objetos que executam com relativa independência em relação a outros, podem ser colocados sobre processos lógicos distintos, visando maximizar o paralelismo. Já os objetos que freqüentemente se comunicam, são colocados sobre os mesmos processos lógicos. Isso é uma forma de evitar uma sobrecarga de comunicação gerada através de muitas comunicações interprocessos. Muitas mensagens congestionam o canal de comunicação, degradando o desempenho do sistema, e por isso, os objetos que mais se comunicam entre si são postos sobre os mesmos processos lógicos, evitando uma sobrecarga desnecessária com a comunicação.

\subsubsection{Rollback no STW}

No STW, a execução de um evento por um determinado processo não leva em consideração o progresso da execução de eventos dos demais processos do sistema, o que implica na possibilidade de ocorrer avanços de alguns relógios locais (LVT) em relação aos demais, em um determinado momento. Pelo fato dos processos lógicos funcionarem de maneira assíncrona, é possível que um processo receba um evento extraviador (straggler), ocasionando um erro de violação de causalidade (figura 6.2). Como forma de recuperar-se, o processo que recebeu o evento extraviador deve realizar rollback para um tempo de simulação anterior à violação de causalidade. Durante o rollback, um processo deve retornar a um estado anterior à violação e cancelar os eventos que foram enviados para outros processos durante a vigência da violação da causalidade. Esse cancelamento é executado através do envio de antimensagens a outros processos, os quais removem os eventos errôneos de suas listas de entrada (figura 6.3). 


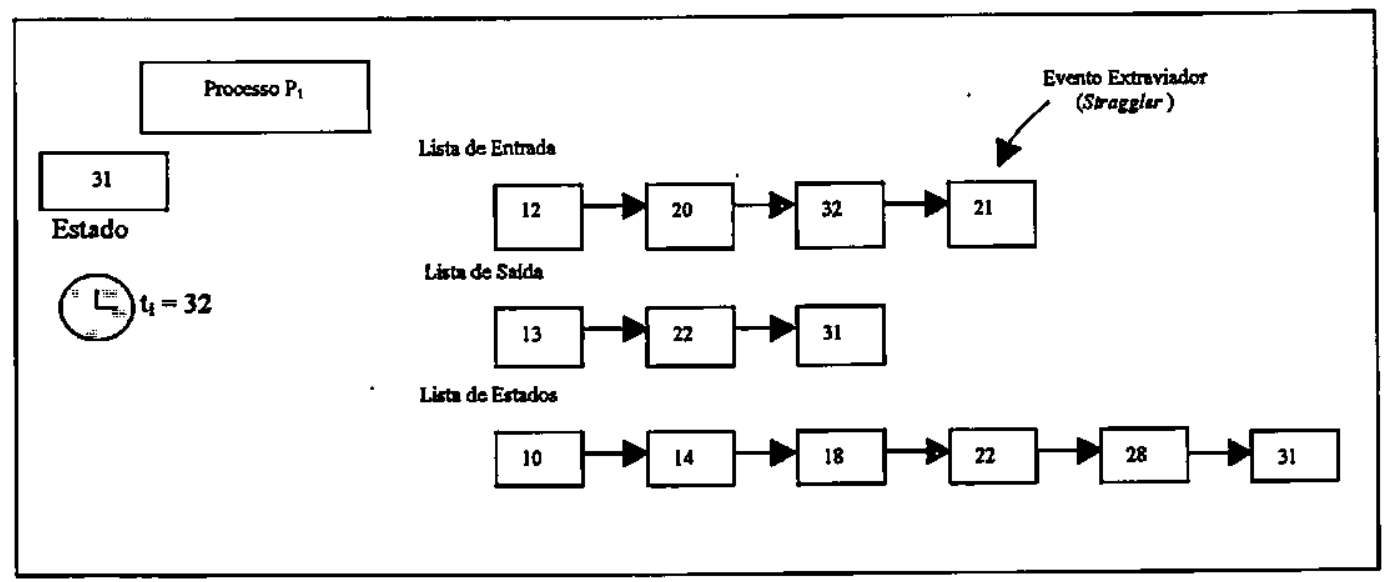

Figura 6.2. Ocorrência de Violação de Causalidade.

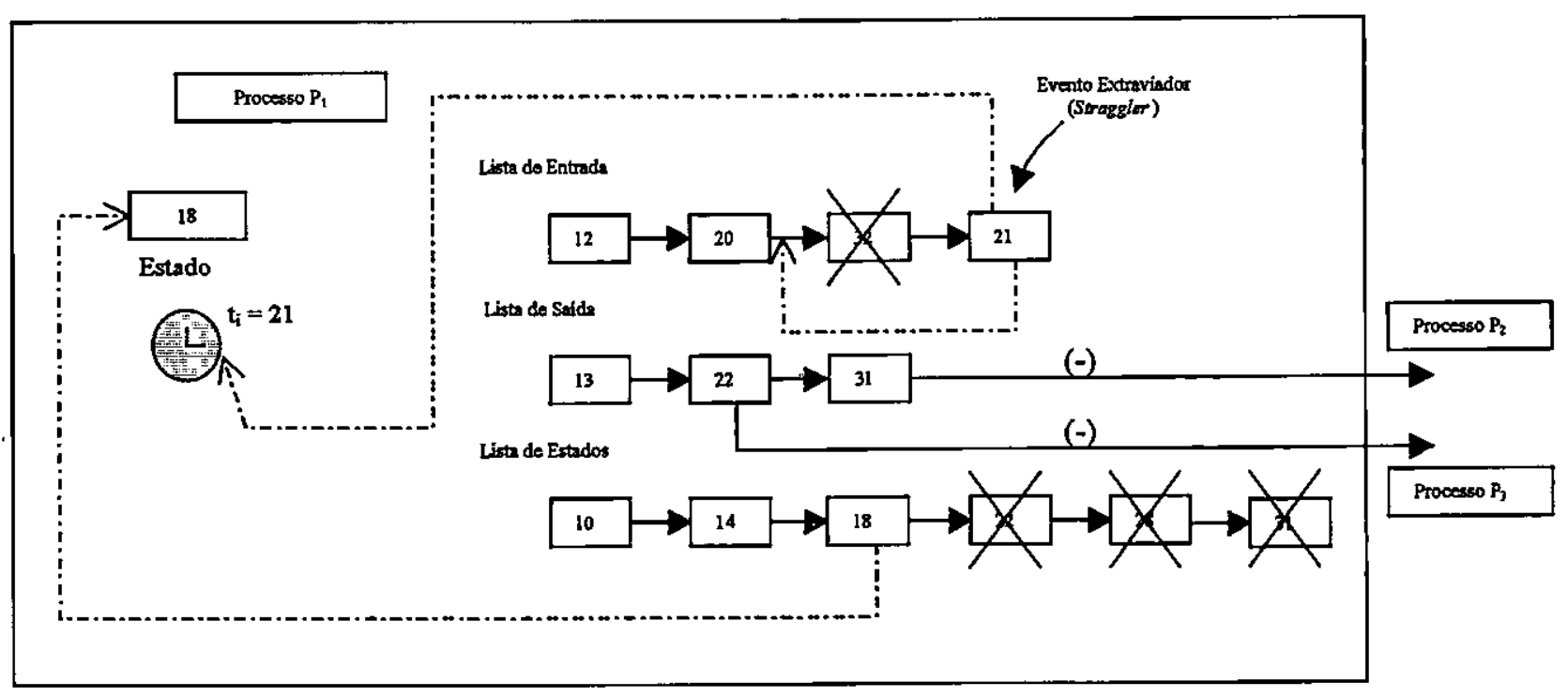

Figura 6.3. Mecanismo de Rollback e Antimensagens.

Como ilustrado na figura 6.2, o relógio-local-(LVT) do processo- $P_{1}$ indica o-tempo-35. Isso quer dizer que o evento cujo timestamp é 35 está sendo executado. Nesse momento, chega ao processo $\mathrm{P}_{1}$ um evento cujo timestamp é 21 (figura 6.3). Isso indica que o processamento realizado por $P_{1}$ entre os tempos 21 e 35 pode estar incorreto. Para desfazer esse suposto erro, o STW ativa o mecanismo de rollback para um tempo anterior à violação de causalidade, ou seja, para o tempo anterior ao valor 21. O LVT do processo é atualizado para 21 . O estado do processo é restaurado para o valor 20. A lista de entrada é atualizada para o evento cujo timestamp é 21 . O processo $\mathrm{P}_{1}$ procura na lista de saída os eventos que foram enviados para outros processos durante o intervalo 21 
a 32. Após essa verificação, $P_{1}$ envia as antimensagens para cancelar os eventos que foram previamente enviados.

\subsubsection{Estratégia de Cancelamento no STW}

Algumas estratégias têm sido desenvolvidas para reparar os danos causados por uma violação de causalidade. As estratégias mais utilizadas em sistemas baseados no paradigma Time Warp são o Cancelamento Preguiçoso e o Cancelamento Agressivo. Essas duas otimizações foram consideradas no STW. A seção 6.2.3 exibe uma especificação formal do STW. Essa especificação divide-se em duas ênfases - Cancelamento Agressivo e Cancelamento Preguiçoso.

\subsubsection{Especificação do STW}

Para gerar uma compreensão mais abrangente de toda funcionalidade do Sistema Time Warp, foi elaborado um modelo em redes de Petri (RP) para o sistema. A intenção é possibilitar uma interpretação formal da semântica do STW, através da utilização da sintaxe das redes de Petri. Com a finalidade de viabilizar o entendimento do modelo, será feita uma introdução às RPs.

As redes de Petri possuem, por definição, dois elementos básicos: os Lugares (representados por círculos) e as transições (representadas por barras). A ligação entre lugares e transições e transições e lugares é feita através de arcos direcionados. Os lugares podem, ainda, possuir marcações (tokens) que determinam o estado em que o sistema se encontra num determinado instante (Maciel et al., 1996). A figura 6.4. apresenta os elementos básicos de uma rede de Petri.

Uma das áreas interessantes para aplicação de redes de Petri é a área da representação de protocolos de comunicação. Em protocolos, geralmente, as transições são bem nítidas (por exemplo, a transmissão ou recepção de uma mensagem). Muitas situações que são mutuamente exclusivas se fazem presentes (como a escolha entre um receptor dentre vários). A figura 6.5 (Maciel et al., 1996) mostra o comportamento de um protocolo bastante simples. Apesar de simples, o modelo apresenta situações interessantes para discussão. 


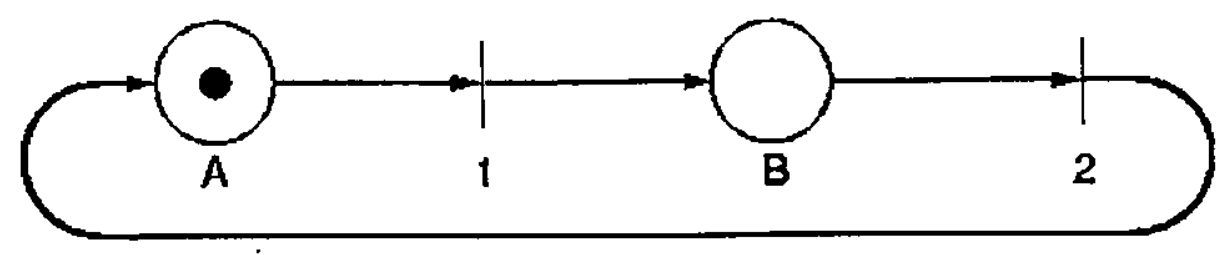

Figura 6.4. Elementos Básicos de uma Rede de Petri.

O funcionamento do protocolo da figura 6.5 se fundamenta basicamente na decisão de qual receptor (1 ou 2) deve aceitar a mensagem. Nesse exemplo específico, a escolha é nãodeterminística, isto é, não se pode decidir qual o arco que o token deve seguir. Além disso, a escolha é mutuamente exclusiva, ou seja, apenas uma das transições será habilitada $\left(t_{2}\right.$ ou $\left.t_{4}\right)$. A escolha citada se processa quando o token, que vem de $t_{0}$, chega ao lugar $\mathbf{P}_{6}$. Nesse ponto, o token ou parte para o Receptorl (habilitando a transição $t_{2}$ ), ou para o Receptor2 (habilitando a transição $t_{4}$ ). A partir daí, após a escolha do receptor, o token segue para um buffer $\left(\mathrm{P}_{3}\right.$ no Receptor 1 , ou $\mathrm{P}_{4}$ no Receptor 2), para ser reconhecido pelo disparo da transição $t_{3}$ (Receptor 1) ou $t_{5}$ (Receptor 2).

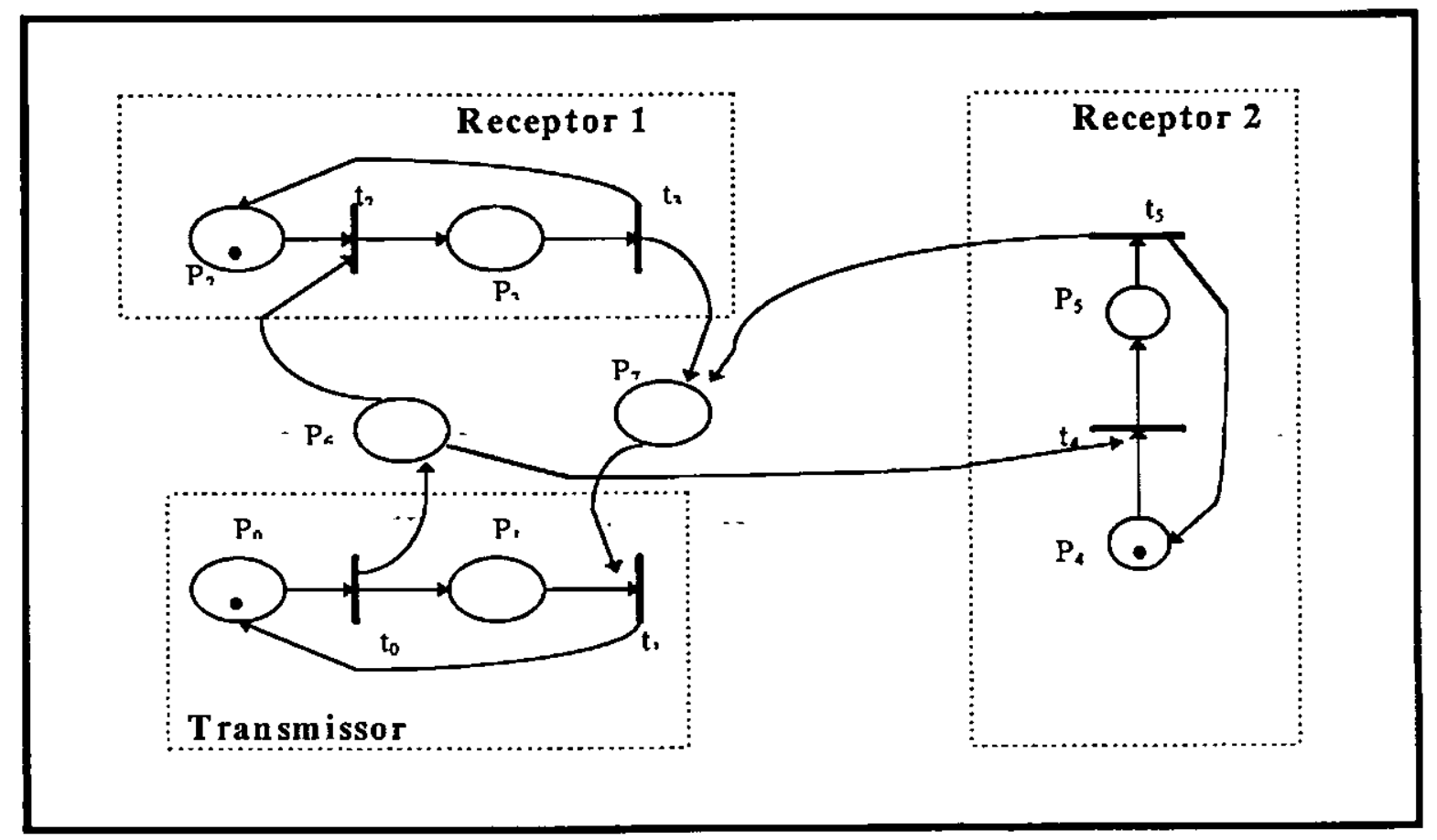

Figura 6.5. Protocolo Simples de Comunicação em Rede de Petri. 
O funcionamento básico do Sistema Time Warp é descrito na figura 6.6, com ênfase para 0 cancelamento agressivo. $O$ modelo apresentado divide a açã่o em duas entidades elementares: 0 Processo Transmissor e o Processo Receptor. Duas tabelas ilustram tanto os lugares dos Processos Transmissor e Receptor (tabela 6.2) quanto as transições desses processos (tabela 6.3). Em seguida, o modelo é apresentado tendo uma nova ênfase, a do cancelamento preguiçoso (figura 6.7). Novamente, os lugares e transições dessa segunda ênfase de cancelamento são organizados e apresentados nas tabelas 6.4 e 6.5 , respectivamente.

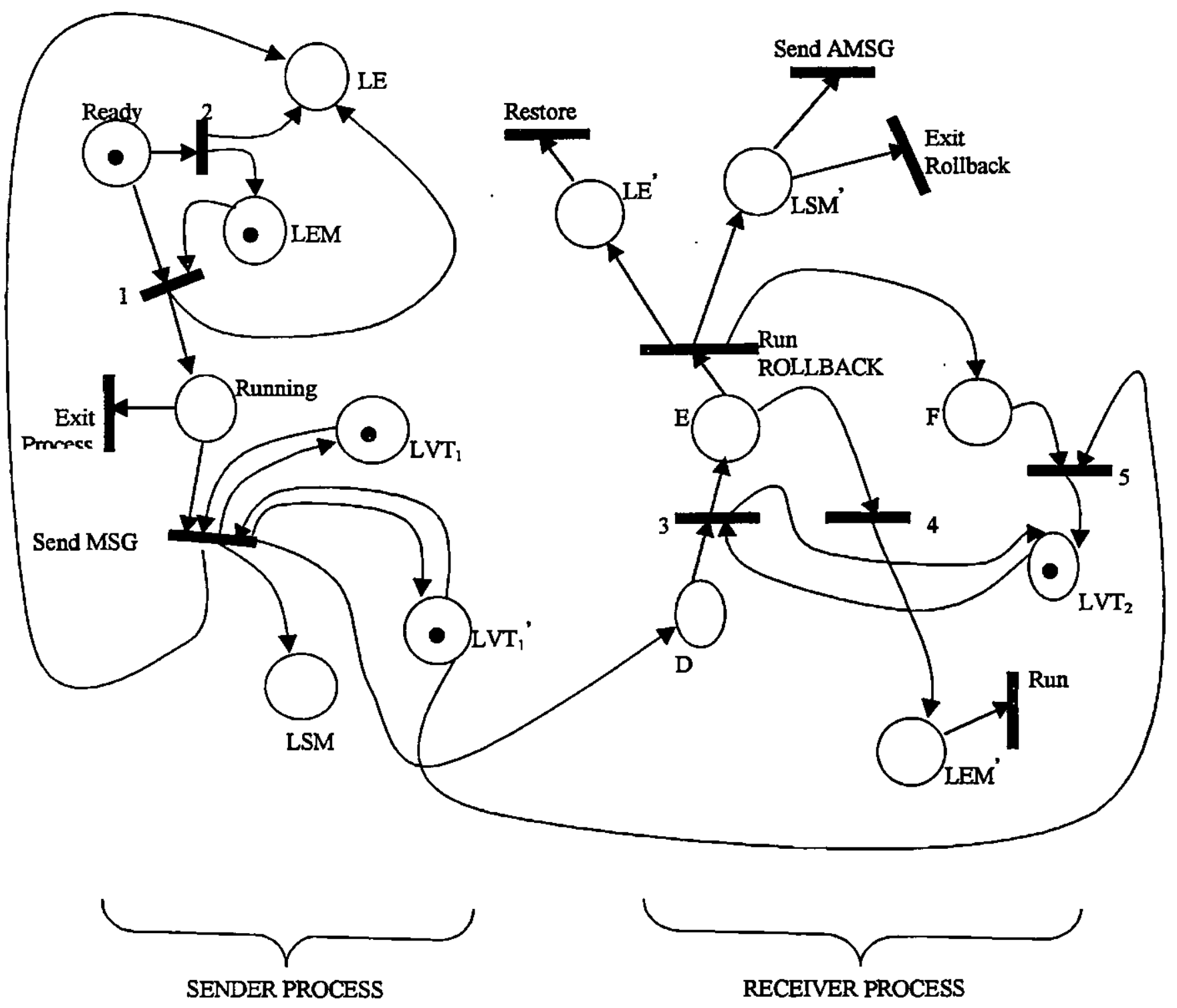

Figura 6.6. Modelo em Rede de Petri para STW, utilizando Cancelamento Agressivo. 


\begin{tabular}{|c|c|}
\hline W f & 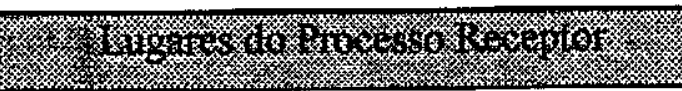 \\
\hline Ready - Processo no estado de Pronto & D - Recebendo Mensagens \\
\hline LE - Lista de estados salvos & E-Tratando Mensagens \\
\hline Running -Processo no estado de executando & F-Atualizando $\mathrm{LVT}_{2}$ \\
\hline $\mathrm{LVT}_{1}-$ Tempo Virtual Local & LE' - Lista de estados salvos \\
\hline $\mathrm{LVT}_{1}^{\prime}$ - Timestamp & $\mathrm{LVT}_{2}$ - Tempo Virtual Local \\
\hline LEM - Lista de Entrada de Mensagens & LEM' - Lista de Entrada de Mensagens \\
\hline LSM - Lista de Saída de Mensagens & LSM' - Lista de Saída de Mer \\
\hline
\end{tabular}

Tabela 6.2. Tabela de Lugares dos Processos Transmissor e Receptor (Cancelamento Agressivo).

\begin{tabular}{|c|c|}
\hline 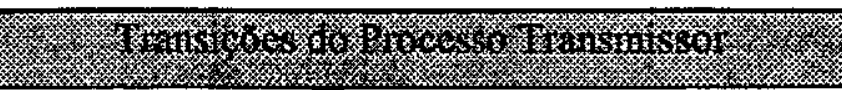 & 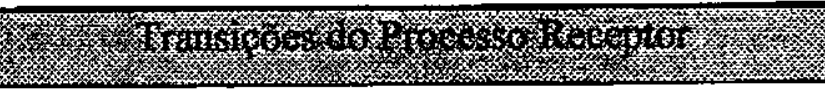 \\
\hline 1 - Executar Processo & 3 - Verificar Timestamp \\
\hline 2 -Salvar estado & 4-Enfileirar Mensagem \\
\hline $\begin{array}{l}\text { Exit Process - Terminar a execução, sem } \\
\text { necessidade do envio de mensagem. }\end{array}$ & Run - Executar mensagem \\
\hline Send MSG - Enviar mensagem & Run ROLLBACK - Executar Rollback \\
\hline & 5- Atualizar LVT 2 \\
\hline & Restore - Restaurar estado anterior ao Rollback \\
\hline & Send AMSG - Enviar Antimensagens \\
\hline & $\begin{array}{l}\text { Exit Rollback - Sair do Rollback sem enviar } \\
\text { antimensagens }\end{array}$ \\
\hline
\end{tabular}

Tabela 6.3. Tabela de Transições dos Processos Transmissor e Receptor (Cancelamento Agressivo).

A semântica da Rede de Petri da figura 6.6 tem seu início no fato de que um processo para se tornar transmissor deve se encontrar no estado de pronto (existência de token no lugar Ready), e deve haver um evento, para ser processado, na lista de entrada de mensagens (existência de token no lugar LEM). Satisfeitas essas condiçōes a transição 1 (processo no estado de executando) pode ser disparada. Ao executar um processo, deve-se atualizar a lista de estado, isto é, passar o processo do 
estado de pronto para o estado de executando (lugar Running). 0 modelo, ao se encontrar em Running, pode realizar duas ações: sair do processo, sem a necessidade de enviar mensagens ou enviar mensagens para um processo receptor. No segundo caso, ainda são necessários o valor do relógio local do processo transmissor e o timestamp (token nos lugares LVT1 e LVT1'). Ao enviar uma mensagem, é necessário que se atualize a lista de estados salvos do processo transmissor, fazer uma cópia da mensagem a ser enviada na lista de saida de mensagens (lugar LSM), e levar a rede para o estado de recebendo mensagem (lugar D). A partir desse estado, as ações já serão realizadas no processo receptor. A primeira ação é verificar timestamp (transição 3). A partir de 3, o modelo transiciona para o estado de tratando mensagem (lugar $\mathrm{E}$ ). A partir de $\mathrm{E}$, podem-se tomar duas atitudes: enfileirar mensagem (em LEM' para posterior execução), caso o timestamp seja maior que o LVT2, ou executar rollback (transição Run ROLLBACK), caso o timestamp seja menor que o LVT2. Na Segunda hipótese, o sistema terá que restaurar o estado salvo antes da violação de causalidade (transição Restore), atualizar o relógio do processo receptor e enviar antimensagens, quando necessário.

Já a figura 6.7 apresenta o comportamento do Sistema Time Warp, utilizando o Cancelamento Preguiçoso. O raciocínio apresentado é o mesmo do Agressivo para o processo transmissor. No que se refere ao processo receptor, a semântica do modelo muda, a partir do tratamento da mensagem, ou seja, quando da ocorrência de rollback. Após a ocorrência do rollback, uma nova lista de entrada de mensagens é gerada (lugar LEMR) e há reexecução da mensagem, o que vai originar outra nova lista de entrada de mensagens a partir de LEM (o lugar LEMA). Após isso, é feita uma comparação entre as duas listas geradas (LEMR e LEMA), ao se disparar a transição compare. De acordo com essa comparação, podem-se tomar duas atitudes: continuar a execução, sem a necessidade de transmissão de antimensagens (transição continue), ou enviar antimensagem (transição Send AMSG). A seguir são apresentadas as tabela do processo receptor (Lugares e Transiçōes, tabelas 6.4 e 6.5, respectivamente). 


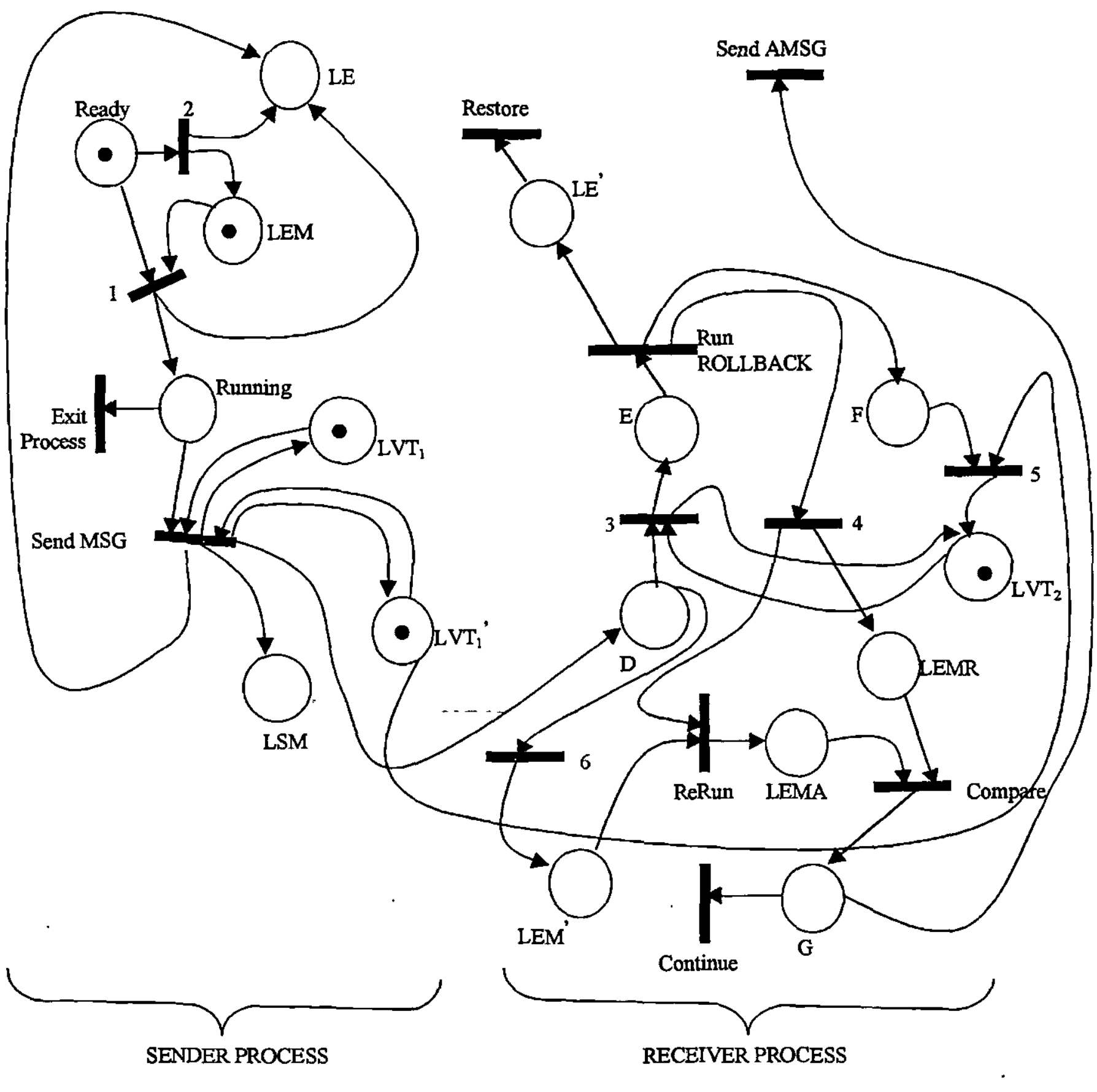

Figura 6.7. Modelo em Rede de Petri para STW, utilizando Cancelamento Preguiçoso. 


\begin{tabular}{|l|}
\hline D - Recebendo Mensagens \\
\hline E - Tratando Mensagens \\
\hline F - Atualizando LVT 2 \\
\hline G - Analisando Comparação \\
\hline LE' $^{\prime}$ Lista de estados salvos \\
\hline LVT $_{2}$ - Tempo Virtual Local \\
\hline LEM' $^{\prime}$ Lista de Entrada de Mensagens \\
\hline LEMA - Lista de Entrada de Mensagens Atualizadas \\
\hline LEMR - Lista de Entrada de Mensagens Após Rollback \\
\hline LSM' - Lista de Saída de Mensagens \\
\hline
\end{tabular}

Tabela 6.4. Tabela de Lugares do Processo Receptor (Cancelamento Preguiçoso).

\begin{tabular}{|l|}
\hline 3 - Verificar Timestamp \\
\hline 4- Atualizar Lista de Entrada de Mensagens, Após Rollback \\
\hline Run - Executar mensagem \\
\hline ReRun - Reexecutar mensagem \\
\hline Compare - Comparar LEMA e LEMR \\
\hline Continue - Continuar a Execução Normalmente \\
\hline Run ROLLBACK - Executar Rollback \\
\hline 5 - Atualizar LVT 2 \\
\hline 6 - Enfileirar Mensagem \\
\hline Restore - Restaurar estado anterior ao Rollback \\
\hline Send AMSG - Enviar Antimensagens \\
\hline
\end{tabular}

Tabela 6.5. Tabela de Transições do Processo Receptor (Cancelamento Preguiçoso). 


\subsection{Implementação do Sistema Time Warp (STW)}

O STW é um conjunto de programas voltado à simulação distribuída orientada a eventos. $\mathrm{O}$ STW foi escrito em $\mathrm{C}++$, utilizando alguns conceitos do paradigma de orientação a objetos, tais como herança, funções virtuais e sobrecarga. $\mathrm{O}$ beneficio deste projeto é que o usuário final pode redefinir e reconfigurar algumas funções do sistema sem precisar mudar o código do sistema. 0 STW é destinado a dois tipos de usuários: aqueles que desejam construir modelos de aplicações distribuídas, e aqueles que desejam apenas experimentar e analisar o STW. O STW apresenta as seguintes caracteristicas:

- Escalonamento: Menor timestamp primeiro. Todos os objetos sobre um processo lógico compartilham uma mesma lista de entrada, e o objeto que possui o evento com o menor timestamp é o próximo a ser escalonado para executar;

- Salvamento Periódico de Estado: $O$ estado do processo é salvo a cada três ocorrência de três eventos;

- Gerenciamento de Lista de Evento: Lista ligada ordenada por:

- Timestamp $\rightarrow$ Lista de entrada de mensagens;

- Tempo Virtual de Envio $\rightarrow$ Lista de saídà de mensagens.

- Estratégias de Cancelamento: Cancelamento Agressivo e Cancelamento Preguiçoso.

No STW, os objetos são modelados como entidades. Os objetos da simulação são organizados em grupos chamados de processos lógicos. Os processos se comunicam através de troca de mensagens, utilizando para isso o ambiente de passagem de mensagens PVM. Os objetos que desejam se comunicar com objetos localizados sobre o mesmo processo lógico, apenas inserem o evento a ser escalonado, na lista de entrada de eventos do processo lógico responsável pelos objetos comunicantes.

\subsubsection{Requisitos Básicos}

O STW foi escrito e compilado usando o compilador GNU C++, g+t, versão 2.7.0. O STW foi projetado para executar sobre o ambiente de passagem de mensagem PVM, versão 3.3. $O$ sistema operacional sobre o qual foi desenvolvido é o LINUX 2.0.30. É possivel desenvolver 
aplicações seqüenciais com STW sem que o PVM esteja instalado no sistema. Mas, se o STW for usado de forma paralela, o PVM deve estar instalado.

\subsection{Classes do STW}

Esta seção descreve as principais classes do STW. Essas classes são desenvolvidas através de técnicas de orientação a objetos. Trechos de algoritmos de algumas classes e métodos que compõem essas classes são apresentados, em virtude de um melhor entendimento do funcionamento dessas classes.

- Classe Evento: A classe Evento é formada por um conjunto de dados que armazena a informação básica necessária para enviar um evento para outro objeto. A definição desta classe encontra-se nos arquivos Evento.h e Evento.cc. Um trecho da definição desta classe é ilustrada a seguir:

class Evento \{

TVirtual tempoEnvio; // tempo virtual de envio do evento

TVirtual tempoChegada; // tempo virtual de chegada do evento (timestamp)

int transmissor, receptor; //identificador do objeto transmissor e objeto receptor

SINAL sinal; // mensagem ou antimensagem

int eventoId;

$/ /$ identificador do evento

unsigned tamanho

// tamanho do evento

\}

ostream\& operator $<<$ (ostream\& os, const Evento\& ev) \{

os <<"Tempo Envio: " < < ev.tempoEnvio<<" Tempo Chegada: " << ev.tempoChegada $<<$

" Objeto Transmissor: " < ev.transmissor<<" Objeto Receptor: "<< ev.receptor $<<$

" Sinal: " < ev.sinal <<" EventoId: " < < ev.eventoId < " tamanho: " < ev.tamanho < <

" Processado: " < ev.jaProcessado;

return os; \} 
Os eventos passados entre os objetos da simulação muitas vezes poderão ser definidos pelo usuário, sem que haja a necessidade de mudar o código do sistema Time Warp. Esses novos eventos geralmente herdam os métodos e dados pertencentes à classe origem Evento.

- Classe TVirtual: Por definição, o STW tem uma simples notação para tempo. Mais precisamente, tempo é definido através da classe TVIRTUAL como um inteiro sinalizado. Um trecho da definição desta classe é exibida a seguir:

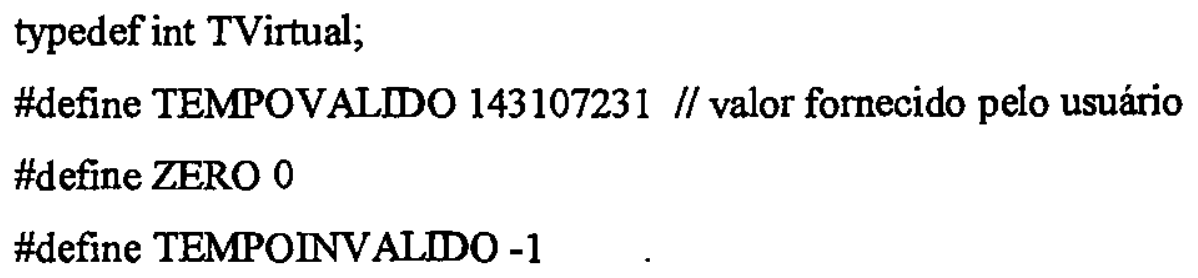

Essa notação foi adotada visando facilitar a manipulação do tempo. Essa definição é utilizada nạ simulação de sistemas, que não precisam de uma definição de tempo complexa. Entretanto, se o sistema a ser simulado precisa de uma definição de tempo mais complexa, como por exemplo sistemas que utilizam a linguagem VHDL. O STW possui um mecanismo para definição de estruturas complexas de tempo. Se a definição original de tempo no STW não for suficiente, o programa do usuário somente necessita definir a macro pré-processadora USUARIO_USA_TVIRTUAL durante a compilação, mais precisamente dentro do programa Makefile. Após isso, o usuário pode definir a classe Tvirtual com os dados apropriados à sua aplicação.

- Classe Estado: O estado de um objeto de simulação STW é o dado que é requerido em qualquer tempo de simulação para fornecer informações sobre o progresso do objeto durante a simulação. Essa classe possui um ponteiro, referenciado por entradaPos, que aponta para o evento que está sendo executado no momento, e um outro, chamado saidaPos, que aponta para o último evento criado até o momento durante a simulação. Ela também armazena o valor do LVT do processo. 
- Classe TwarpBasico: A classe TwarpBasico contém dados comuns a qualquer processo Time Warp. Esses dados incluem uma lista de entrada de mensagens (EntradaLST), uma lista de saida de mensagens (SaidaLST) e o tempo virtual local (LVT) de um processo. A lista de entrada armazena os eventos que os processos necessitam executar, possivelmente alguns desses eventos já tenham sido processados, mas continuam armazenados na lista como forma de garantir a realização de futuros rollbacks. A lista de saída (SaidaLST) armazena eventos que foram gerados e enviados para outros objetos. No STW, cada processo Time Warp possui sua própria definição de estado. Por isso, cada processo precisa definir seu estado, antes de ser utilizado na execução da simulação.

- Classe Twarp: A classe Twarp define todos os métodos necessários para um processo interagir com os outros processos do sistema. Essa classe herda todos os métodos e dados da classe TwarpBasico, ou seja, a lista de estrada de mensagens, a lista de saída de mensagens, o LVT e todas as funções e dados que compõem a classe TwarpBasico.

Durante uma simulação STW, as atividades realizadas durante um ciclo de simulação são:

$>$ Executar uma ou mais chamadas à função getEvento(), para obter os eventos que serão processados durante o ciclo de simulação;

$>$ Processar o(s) evento(s) usando o estado corrente para acessar informações de estado e armazenar novos estados;

$>$ Enviar quaisquer novos eventos gerados a outros processos através de chamadas à função enviaEvento();

$>$ Retornar o controle ao STW.

As atividades citadas acima são realizadas tanto pela aplicação do usuário como pelo sistema STW. Isso é possível porque durante o processamento de uma aplicação, o controle da execução alterna-se entre a aplicação do usuário e o STW. No fim da execução o controle volta a ser somente do STW. 


\section{- Métodos definidos na classe Twarp:}

a) inicializa0: Este método não manipula nenhum parámetro e é chamado para instanciar todos os objetos e processos envolvidos na simulação.

b) finaliza0: Este método é chamado no final da simulação.

c) executaProcesso(): Este método define o comportamento do objeto de simulação quando ele é escalonado para a ser executado. Se um objeto não possui nenhum evento para processar, ele é considerado disponível e não será escalonado.

d) getEvento 0: Este método é usado para obter o próximo evento a ser executado.

e) void enviaEvento(Evento ${ }^{*}$ ): Este método obtém um ponteiro para um Evento (ou um tipo derivado de Evento) como um argumento e o entrega para o processo especificado por Evento::receptor.

f) void rollback(TVirtual): Este método é chamado pelo próprio objeto, quando a lista de entrada registra que o evento recebido estava no passado. Esse método restaura o estado e envia as antimensagens (mensagens negativas) baseado no tempo de recebimento do evento. Um trecho do algoritmo do rollback é mostrado a seguir.

Se (timestamp do evento que chegou < LVT)

entao

Inicio // executa rollback

rollback(tempo anterior à violação);

Procura evento anterior à violação; estado.corrente $\rightarrow \mathrm{LVT}$; // restaura estado do processo

Restaura estado anterior à violação;

LVT $\rightarrow$ timestamp do evento que chegou;

Atualiza relógio local, lista de entrada, lista de saída e lista de estados; contaRollback $=$ contaRollback +1 ;

Atualiza número de rollbacks; fim.

g) void recebeEvento(Evento *): Este método é utilizado por um processo que deseja 
receber um evento de outros proçessos.

h) cancelaMensagemAgressivamente(const TVirtual tempoRollback): Usado durante 0 cancelamento agressivo para enviar as mensagens negativas (antimensagens) que possuem a finalidade de eliminar as mensagens positivas, cujos tempos de envio sejam maiores que o determinado no parâmetro tempoRollback.

i) bool cancelamentoPreguicoso(Evento ${ }^{*}$ ): Este método é usado durante cancelamento preguiçoso, para determinar se o mesmo evento foi gerado depois do rollback ou não.

j) bool cancelaMensagemPreguicosa (Evento * paraEnviar): Este método é usado durante o cancelamento preguiçoso, para determinar se o evento reexecutado deve ser enviado ou não.

1) void moveMsgParaLstCancelamentoPreguicoso(TVirtual): Este método é usado para mover todos os eventos que possuem tempo de envio maior que o TVirtual para a lista LstCancelamentoPreguicoso. Esse armazenamento possibilita que os eventos da lista possam ser usados para fazer comparações com os eventos regenerados após o rollback.

- Classe EntradaLST: Essa classe armazena em uma lista ligada, chamada de lista de entrada, os eventos que chegam em um determinado processo. Esses eventos são dispostos na lista de forma ascendente de seus timestamps. A coerência temporal depende diretamente da chegada dos eventos num processo qualquer, pois o tempo de chegada do evento deve ser, no mínimo, igual ou maior que o LVT do processo receptor. Para verificar a ocorrência de eventos "no passado" (straggler) na lista de entrada, a classe EntradaLST possui um método que ao inserir um evento na lista de entrada faz uma comparação entre os valores do timestamp do evento e do LVT do processo receptor. Se a função retorna o valor booleano verdade, então o evento está "no passado"; no entanto, se o valor retornado é falso, o evento está de acordo com o sincronismo temporal do processo que o recebeu.

- Classe SaidaLST: Esta classe armazena em uma lista ligada, chamada de lista de saída, uma cópia de cada evento que foi enviado para si próprio ou para outros processos. Essa lista é ordenada pelo tempo de envio dos eventos. A única diferença entre os eventos armazenados na lista de saida e os eventos localizados em uma lista de entrada é o campo sinal, que é negativo na lista de 
saída e positivo na lista de entrada. Esses eventos negativos (antimensagens) são enviados para os processos que receberam os eventos enviados durante a violação da causalidade.

- Classe EstadolsT: Esta classe armazena em uma lista, chamada lista de estados, os estados salvos de um processo durante a simulação. A lista é ordenada através dos tempos virtuais locais (LVTs) do processo. No STW, o salvamento dos estados do processo é realizado a cada ciclo da simulação, ou seja, após um ciclo da simulação uma cópia do estado do processo é inserida na lista de estados.

- Classe Processologico: Esta classe é formada por um ou mais processos que compartilham o gerenciador de comunicação (GerenciadorCom), o gerenciador de GVT (GerenciadorGVT) e um escalonador (Escalonador). O laço principal da execução encontra-se no método ProcessoLogico::simula, que informa ao processo lógico para permanecer executando o laço da simulação até receber o tempo definido por SMMULA_ATE.

A classe ProcessoLogico é instanciada através de um construtor que possui três inteiros como argumentos: 1) $\mathrm{O}$ número total de objetos no sistema, 2) $\mathrm{O}$ número de objetos contido em um processo lógico e 3) $\mathrm{O}$ número de processos lógicos que serão utilizados durante a simulação.

Um ProcessoLogico utiliza o método registraObjeto para registrar todos os objetos armazenados sobre ele. Após o registro de todos os processos, faz-se uma chamada ao método ProcessoLogico::simula, que utiliza o parâmetro TVirtual para determinar que a simulação deverá executar até que o tempo da simulação exceda o valor especificado por TVirtual. Se esse parâmetro não for especificado, então a simulação executará até se completar.

\section{- Classes Gerenciadoras:}

>Classe GerenciadorCom: Esta classe define as funções requeridas para comunicação entre processos lógicos sobre PVM. Comunicação entre objetos de simulação locais ocorre através da inserção direta de eventos na lista de entrada, sem o envolvimento do gerenciador de comunicação. ProcessoLogicos enviando eventos para destinos remotos utilizam o gerenciador de comunicação para esse envio. 
- Método da Classe ProcessoLogico:

- simula: Este método contém o loop principal que orienta uma simulação. Esse loop executa as seguintes ações em cada ciclo de simulação: 1) o gerenciador de comunicação recebe mensagens de outro subsistema e as envia para seus destinos; 2) o escalonador seleciona o próximo ProcessoLogico para execução.

\subsection{Resultados}

Os resultados estatísticos obtidos com o STW podem ser escritos em um arquivo fisico de saída, criado diretamente pelo sistema, ou podem ser enviados diretamente para a tela do computador. A escolha deve ser realizada no arquivo config.h (arquivo de configuração). Dentre os resultados estatísticos obtidos encontram-se o número total de rollbacks ocorridos e o número de eventos processados durante a simulação.

\subsection{Arquivo de Configuração (Config.h)}

O arquivo de configuração Config.h, permite o usuário do STW alterar as características de funcionamento do sistema sem precisar mudar o código do STW. Após alguma alteração realizada no arquivo de configuração, deve-se recompilar o STW através do programa Makefile. As opções presentes no arquivo config.h são:

1. EscalonadorLSTF;

2. Sequencial;

3. Cancelamento Agressivo;

4. Cancelamento Preguiçoso;

A estrutura do arquivo cabeçalho Config.h é apresentada a seguir:

$$
\begin{aligned}
& \text { \#define SEQUENCIAL } \\
& \text { \#define ESCALONADOR_LTSF } \quad / / \text { flag usado para indicar que a simulação será sequencial } \\
& \text { \#define CANCELAMENTO_PREGUICOSO habilitar Escalonador LTSF } \\
& \quad / / \text { flag usado para habilitar o cancelamento } \\
& \quad / / \text { preguicoso }
\end{aligned}
$$


1

// Estratégias de Cancelamento

\#ifdef CANCELAMENTO_PREGUICOSO

// Ele move as mensagens para a lista ListaCancelPreguicoso durante o Cancelamento

// Preguicoso

\#define CANCELA_MENSAGENS (tempoRollback) moveMsgParaListaCancelPreguicoso (tempoRollback)

\#define TESTE_CANCELA_PREGUICOSO(eventPtr) Cancelamento_Preguicoso(eventPtr)

\#else // Cancelamento Agressivo

\#define CANCELA_MENSAGENS (tempoRollback) cancelMsgAgressivamente (tempoRollback) \#endif

/--.-Fim do Arquivo Config.h

As opções do arquivo Config.h são ativadas através da retirada dessas opções como comentário. A opção é definitivamente ativada quando o arquivo Config.h, fazendo parte de outros . programas, é recompilada através do programa Makefile.

\subsection{Considerações Finais}

Este capítulo apresentou o STW a partir de visões e técnicas que, de diferentes ângulos, procuraram mostrá-lo como um todo.

Uma visão interessante, que foi apresentada através das redes de Petri, enfatizou diferenças significativas na utilização da estratégia de cancelamento. A despeito da discussão em torno dessas estratégias, ambas foram consideradas no STW, ressalvando-se apenas que o cancelamento agressivo foi tomado como padrão.

Após essa visão mais abstrata, o STW foi observado em um nivel mais próximo da efetiva implementação. Nesse momento, requisitos básicos foram estabelecidos, com o objetivo de prover suporte a uma explanação das principais classes que compõem o sistema. Foi enfatizada a utilização da orientação a Objetos, que traz consigo vantagens como portabilidade e reutilização mais natural 
do código. Ainda foram delimitadas algumas características-chave do STW (como escalonamento e gerenciamento de lista de eventos).

Toda a abordagem provida neste capítulo visa servir de fundamentação teórica e de alicerce para a próprio implementação do Sistema Time Warp. No próximo capítulo, será apresentado um estudo de caso, através do qual pretende-se verificar a utilização e validação dos conceitos apresentados neste capítulo. 


\section{Capítulo 7}

\section{Estudo de Caso e Análise dos Resultados}

\section{SimTW - Biblioteca para Simulação de Modelos de Filas}

Este capitulo apresenta a biblioteca SimTW, desenvolvida neste projeto, visando a construção de modelos de sistemas de filas. $O$ desenvolvimento do estudo de caso deste projeto é abordado neste capítulo. A análise dos resultados obtidos com o experimento do exemplo de aplicação também é mostrada neste capitulo.

\subsection{Considerações Iniciais}

A biblioteca SimTW, construída sobre o STW, destina-se à construção de sistemas de filas. A biblioteca SimTW é um conjunto de classes $\mathrm{C}++$ que permite a criação de aplicações que simulem sistemas de filas de forma seqüencial ou paralela.

Antes de iniciar a explanação sobre a biblioteca SimTW, o estudo de caso e a análise dos resultados, dar-se-á um breve comentário sobre o assunto Teoria de Filas. A próxima seção (seção 7.2) destina-se à apresentação de sistemas de redes de filas. A seção 7.3 destina-se à explicação da biblioteca SimTW, enfatizando, sobretudo, a sua implementação e utilização. A seção 7.4 detalha a implementação dos objetos que constituem o SimTW. A seção 7.5 exibe a interação entre o STW e a biblioteca SimTW. A seção 7.6 descreve o estudo de caso. A seção 7.7 expõe os resultados obtidos com a simulação. A seção 7.8 comenta os resultados obtidos e a seção 7.9 apresenta as considerações finais. 


\subsection{Teoria de Filas}

A teoria de filas é um ramo da probabilidade que estuda o fenômeno da formação de filas de solicitantes de serviços providos por um determinado recurso. Há vários sistemas que são propícios à formação de filas. Os elementos de um sistema de fila são os clientes e os servidores. Alguns exemplos de sistemas de filas são mostrados na tabela 7.1 (Banks et al, 1996). Um sistema computacional é um exemplo típico desses sistemas, pois, normalmente, há mais requisitantes do que prestadores de serviços.

Um sistema real (computacional ou não) geralmente possui recursos propícios à formação de filas (Kleinrock, 1975). Denomina-se rede um conjunto desses recursos interconectados de alguma forma. Por sua vez, uma fila é uma linha de espera pela utilização de um determinado recurso. Assim, um modelo de redes de filas é uma representação em alto nível dos recursos de um dado sistema.

Pode-se concluir, então, que modelagem de rede de filas em computação, nada mais é do que um método particular de utilização da teoria de filas, onde se associa um sistema computacional a uma rede de filas, para então poder avaliá-lo (Soares, 1992).

\begin{tabular}{|l|l|l|}
\hline \multicolumn{1}{|c|}{ SISTEMA } & \multicolumn{1}{|c|}{ CLIENTE } & \multicolumn{1}{c|}{ SERVIDOR(ES) } \\
\hline Recepção & Pessoas & Recepcionista \\
\hline Hospital & Pacientes & Enfermeiro/Médico \\
\hline Computador & jobs ou tarefas & CPU, disco, fitas \\
\hline Telefone & Chamadas & Permutador \\
\hline Banco & Cliente & Caixa \\
\hline
\end{tabular}

Tabela 7.1. Exemplos de Sistemas de Filas

\subsubsection{Redes de Filas}

Uma rede de filas é uma coleção de centros de serviço, os quais representam recursos do sistema, e clientes que representam usuários ou transações dispostos em áreas de espera (filas), os 
quais, de alguma forma, solicitam a prestação de um serviço a um determinado servidor, dentro dos centros (Soares, 1992).

Centros de serviço são entidades prestadoras de serviços aos clientes solicitantes. Esses centros podem possuir servidores únicos ou múltiplos, dependendo do número de recursos disponíveis no modelo. A figura 7.1 ilustra a representação de um centro de serviço com um servidor, e a figura 7.2 apresenta múltiplos centros de serviço, onde cada um possui apenas um servidor (Francês, 1998).

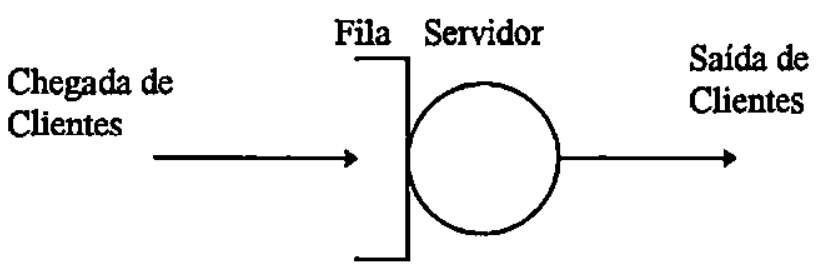

Figura 7.1. Um centro de Serviço com um Único Servidor.

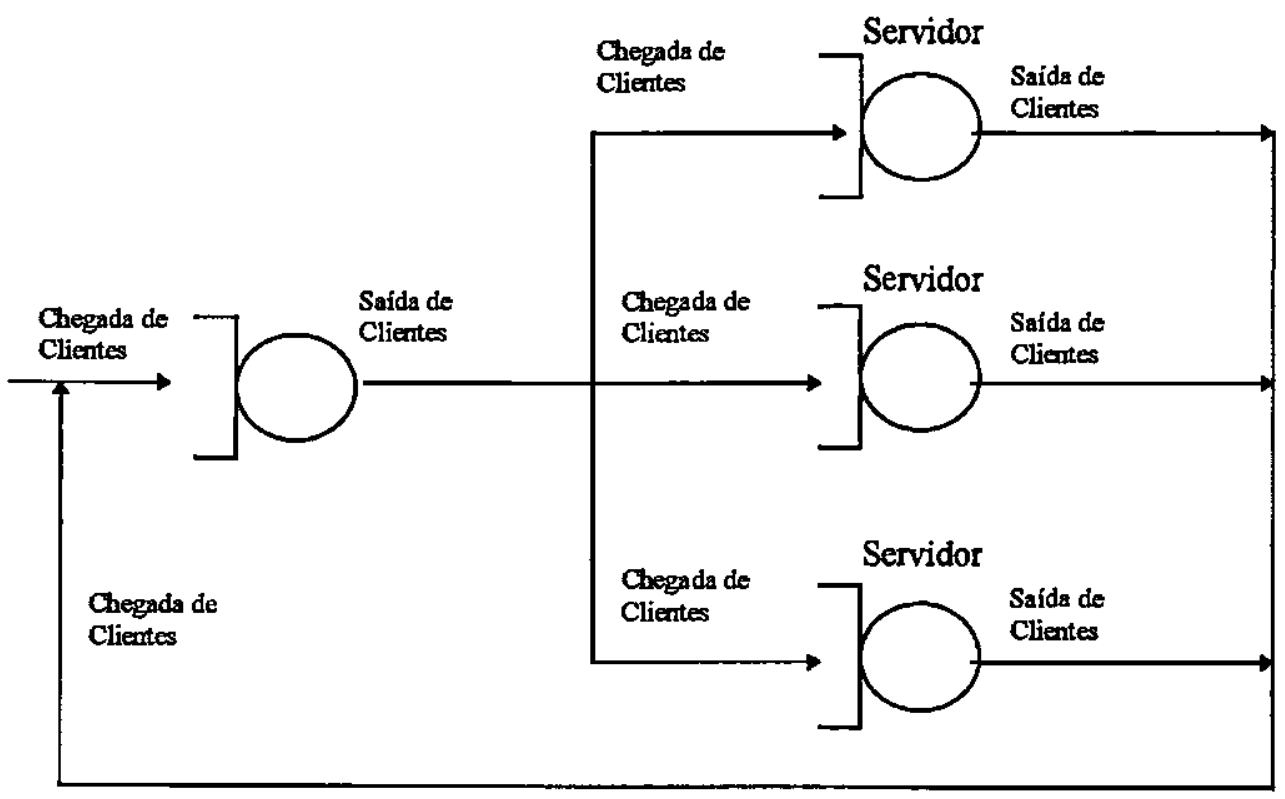

Figura 7.2. Múltiplos Centros de Serviço com apenas um Servidor. 


\subsubsection{Notação para Sistemas de Filas}

A notação de um sistema de filas é baseada em seis parâmetros: a distribuição dos tempos entre chegadas (A), a distribuição do tempo de serviço (B), o número de servidores (c), a capacidade do sistema (K), o número de clientes na fonte $(\mathrm{m})$ e a disciplina de fila (Z) (Kleinrock, 1976). A associação de tais parâmetros origina a notação $\mathrm{A} / \mathrm{B} / \mathrm{c} / \mathrm{K} / \mathrm{m} / \mathrm{Z}$. Os símbolos (e seus significados) usados para A e B são:

G distribuição de tempo entre chegadas independente geral ou tempo de serviço geral;

Hk distribuição de tempo de serviço ou de tempo entre chegadas hiperexponencial de estágio k;

Ek distribuição de tempo de serviço ou de tempo entre chegadas Erlang de estágio k;

M distribuição de tempo de serviço ou de tempo entre chegadas exponencial;

D distribuição de tempo de serviço ou de tempo entre chegadas determinístico, ou seja, tempo de serviço ou de tempo entre chegadas são valores constantes.

Uma simplificação da notação $\mathrm{A} / \mathrm{B} / \mathrm{c} / \mathrm{K} / \mathrm{m} / \mathrm{Z}$ usualmente empregada é a notação $\mathrm{A} / \mathrm{B} / \mathrm{c}$, onde admite-se que não existe limite para o tamanho da fila, a fonte de clientes é infinita, e a disciplina da fila é FCFS (First Come - First Served, primeiro a chegar, primeiro a ser servido) (Orlandi, 1995). Assim, um sistema de fila $\mathrm{M} / \mathrm{M} / 1$ é aquele caracterizado por apresentar taxas de chegadas entre clientes e tempo de serviço obedecendo à distribuição exponencial e possuindo um único servidor (Kleinrock, 1976). A notação $G$ denota a utilização de distribuições arbitrárias (Kleinrock, 1976), que, por exemplo, pode não ser nenhuma das distribuições já citadas ou um conjunto delas.

Pelo fato dos elementos representativos de um sistema de fila sempre obedecerem a uma forma de distribuição de probabilidade, as principais distribuições serão discutidas na próxima seção. 


\subsubsection{Distribuições de Probabilidade}

Nesta seção serão apresentadas algumas das principais distribuições de probabilidade (contínua e discreta). Objetivando tão somente fornecer subsídios aos interesses deste trabalho, serão apresentadas as seguintes distribuições: Uniforme, Exponencial, Binomial, Normal e de Poisson. As distribuições são discutidas de maneira abreviada (para obtenção de maiores detalhes, consultar (Dantas, 1997), (Francisco, 1993), (Farias et al., 1991)).

- Distribuição Uniforme: é a distribuição contínua que especifica que valores compreendidos entre um máximo e um mínimo são equiprováveis. $O$ uso dessa distribuição geralmente se processa quando há um total desconhecimento da variável aleatória1, conhecendo-se apenas seus limites.

- Distribuição Exponencial: é a distribuição cuja probabilidade de acontecer um evento em um pequeno intervalo de tempo é proporcional ao tamanho desse intervalo. Se a probabilidade de ocorrência de mais de um evento nesse intervalo é nula e se a probabilidade de ocorrência de um evento é independente da ocorrência de outros, então o intervalo entre ocorrências possui uma distribuição exponencial. Essa distribuição possui algumas características interessantes à modelagem (principalmente quando se utiliza a solução analítica). Uma característica que interessa à resolução analítica é o fácil tratamento matemático dessa distribuição, sendo por isso, muitas vezes assumida em vários estudos. A distribuição exponencial possui uma variância elevada, ou seja, admite uma grande disparidade entre valores, fato que é interessante em um estudo de filas.

- Distribuição de Binomial: é a distribuição da variável aleatória discreta construída pelo número de vezes que ocorre determinado evento, quando a probabilidade desse evento for constante em cada prova.

1 É uma regra de associação de um valor numérico a cada ponto de um espaço amostral. Por exemplo, em um lançamento de duas moedas $(\mathrm{k}=$ cara e $\mathrm{C}=$ coroa), o espaço amostral é $\mathrm{E}=\{\mathrm{KK}, \mathrm{KC}, \mathrm{CK}, \mathrm{CC}\}$ e KK pode ser associada à variável aleatória de valor 2 (Farias et al., 199l). 
- Distribuição Normal: distribuição baseada no Teorema do Limite Central, que afirma que ao realizar-se uma seqüência de experimentos independentes, o resultado de cada um deles é expresso pela mesma distribuição de probabilidade ou, em outras palavras, por variáveis aleatórias independentes e identicamente distribuídas com média $\mu$ e variância $\sigma^{2}$, então para um número $n$ de parcelas suficientemente grande $S_{n}=X_{1}+X_{2}+\ldots+X_{n}$ tem distribuição de probabilidade aproximadamente normal com média $n \mu$ e variância $n \sigma^{2}$.

- Distribuição de Poisson: é a distribuição discreta que estabelece que se a duração do intervalo de tempo entre chegadas é exponencialmente distribuído e se as chegadas ocorrem uma de cada vez, então o número de chegadas em um intervalo fixo qualquer possui uma distribuição de Poisson. As chegadas de clientes em uma fila geralmente se dăo de maneira discreta (e não contínua), por esse motivo, a distribuição de Poisson é bastante representativa às chegadas de clientes a um sistema de filas.

As distribuiçōes de probabilidades representam o padrão em que os clientes chegam a um centro de serviço e também o padrão de tempo de serviço destinado a cada cliente. Entretanto, elas não definem qual a ordem de atendimento dos clientes. Essa ordem é estabelecida através de algoritmos de escalonamento denominados disciplina de filas (Kleinrock, 1975), (Kleinrock, 1976), (Soares, 1992). Os principais escalonamentos são discutidos a seguir.

\subsubsection{Disciplinas de Atendimento aos Clientes}

A disciplina de fila é o mecanismo responsável por decidir qual deverá ser o próximo cliente a ser atendido pelo servidor (Soares, 1992). Algumas das técnicas mais usuais são:

FCFS (First Come - First Served) é uma disciplina bastante comum e muito usada. Ela baseia o seu atendimento na ordem de chegada dos clientes, isto é, o primeiro a chegar será o primeiro a sair. Essa disciplina não é apropriada para filas cujos clientes possuam prioridade, ou seja, clientes que exigem um tratamento diferenciado.

A disciplina LCFS (Last Come - First Served) é exatamente o oposto da FCFS, ou seja, o último a chegar será o primeiro a ser atendido pelo servidor. Essa disciplina possui a estrutura de uma pilha. 
RR (Round Robin) é a disciplina na qual um cliente é atendido durante um pequeno intervalo de tempo, denominado quantum. Caso esse intervalo não seja suficiente para a realização de todo o serviço requisitado pelo cliente, este é colocado no final da fila novamente, até que o seu serviço seja completado.

As filas, entretanto, podem requerer a atribuição de prioridades para os clientes. As prioridades podem ser preemptivas, isto é, o atendimento de um cliente é interrompido caso chegue um cliente com maior prioridade, ou não preemptivas, ou seja, o cliente em atendimento não é afetado, porém o próximo a ser atendido será sempre o de maior prioridade.

\subsection{A Biblioteca SimTW}

Como já citado anteriormente, SimTW é uma biblioteca destinada à construção sistemas de filas. Ela é formada por um conjunto de classes $\mathrm{C}++$. Ela fornece ao usuário uma biblioteca de objetos, com os quais ele pode modelar vários tipos de aplicações que envolvem sistemas de filas.

As aplicações de sistemas de filas construídas utilizando os objetos da biblioteca SimTW podem possuir uma ou mais filas. Como já citado anteriormente, um modelo no qual tarefas, jobs ou clientes partem de um serviço para outra fila (possivelmente podem retornar à fila do mesmo serviço) é chamado de Rede de Filas. Uma rede de filas pode ser classificada em dois tipos: 1) Uma rede de fila aberta ou 2) Uma rede de fila fechada. Uma rede de fila aberta apresenta chegadas e partidas externas, ou seja, as tarefas ou os clientes chegam, são atendidos e partem do sistema através de entidades externas ao sistema. Uma rede de fila fechada não possui chegadas ou partidas externas. As tarefas ou os clientes do sistema permanecem circulando de um centro de serviço para outro. Em geral, em um sistema fechado a saida do sistema encontra-se diretamente ligada à entrada do sistema. As tarefas ou os clientes que "saem" do sistema imediatamente reentram no sistema.

A biblioteca SimTW é constituída por sete objetos:

- Fonte, Fork, Join, Delay, Fila, Servidor e Saída. As representações gráficas desses objetos foram obtidas em (Nair \& Sauer, 1985), exceto a representação do objeto Delay. 


\subsubsection{Fonte}

Em sistemas de filas, o objeto Fonte representa o lugar no qual os clientes são gerados. A função do objeto Fonte é produzir tokens ou eventos. Esses eventos ou tokens são roteados entre os objetos Fork/Fila/ Join e atendidos ou processados nos objetos Servidor e Saida. Cada objeto Fonte possui uma função distribuição que realiza a distribuição de tokens entre os objetos. A escolha da forma de distribuição pode ser realizada entre as seguintes:

- Normal

- Poisson

- Binomial

- Exponencial

- Uniforme

- Fixa

O gerador de números aleatórios usado para fornecer essas distribuições é o Multiplicative Linear Congruential Generator (MLCG). Esse gerador foi escolhido por ser considerado um dos mais estável e simples geradores de números aleatórios (Warped, 1996). Além das distribuiçõeś citadas na seção 7.2.3, o objeto fonte também pode utilizar a distribuição Fixa. Essa distribuição gera tokens em um intervalo fixo de tempo.

\section{- Representação Gráfica:}

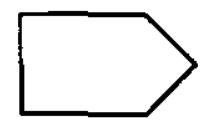

A figura 7.3 apresenta a representação gráfica de um sistema de fila. Esse sistema representa um banco, em horário normal de funcionamento. Na figura, o objeto Fonte reproduz a entrada de clientes no banco.

\subsubsection{Fork}

O objeto Fork distribui tokens de entrada com diferentes caracteristicas de distribuição. Os tokens de entrada do objeto Fork podem ser, por exemplo, a entrada de clientes em um sistema de filas. O Fork passa seus tokens de entrada para uma ou mais saídas dèpendendo da característica de 
distribuição determinada pelo usuário. As escolhas podem ser ALTERNADO, ROUND-ROBIN, TODOS, CONDICIONAL e ESPECIAL. A descrição desșas formas de distribuição é apresentada a seguir:

- ALTERNADO: Os tokens são distribuídos de maneira alternado entre os destinos;

- TODOS: Os tokens são enviados para todos os destinos;

- CONDICIONAL: Os tokens são enviados para um destino determinado por alguma condição;

- ROUND-ROBIN: Os tokens são distribuídos durante um intervalo de tempo;

- ESPECIAL: Os tokens são distribuídos através de quaisquer funções de distribuições citadas na seção 7.2.3.

$\mathrm{Na}$ figura 7.3, o objeto Fork distribui os clientes de acordo com uma distribuição CONDICIONAL. Nessa distribuição, um cliente será roteado para um fila com dois caixas (2 servidores), se ele for cliente especial do banco, ou será roteado para uma fila com apenas um caixa (1 servidor), se ele não for cliente especial do banco.

- Representação Gráfica:

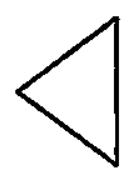

\subsubsection{Join}

O objeto Join transporta os tokens que saem do objeto Servidor para o objeto Saída.

$\mathrm{Na}$ figura 7.3, o objeto Fork é representado pelo término do atendimento do cliente pelo caixa. Se o cliente não precisar mais de nenhum outro serviço do banco, ele se conduz para a saída do recinto.

\section{- Representação Gráfica:}

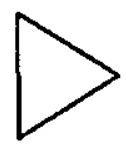

\subsubsection{Delay}

O módulo Delay é um módulo comum em redes de filas. Os tokens que passam através do módulo Delay são atrasados para um intervalo determinado probabilisticamente ou para um intervalo fixo. O tempo de atraso (delay) fixo pode ser usado para modelar vários atrasos associados com diferentes elementos de um projeto. $O$ tempo de atraso pode ser um intervalo de atraso 
determinado probabilisticamente, com uma distribuição que poderia ser Uniforme, Poisson e Normal.

Na figura 7.3, o objeto Delay pode representar o atraso na demora do atendimento de um cliente por um caixa.

- Representação Gráfica:

\subsubsection{Fila}

O objeto Fila é definido com um buffer e uma disciplina de filas. A disciplina de fila pode ser FCFS (First Come - First Served), o primeiro a entrar é o primeiro a se atendido, ou LCFS (Last Come - First Served), o último a entrar é o primeiro a se atendido. $O$ objeto fila é projetado para trabalhar com um servidor ou vários servidores. Um objeto fila armazena mensagens que recebe em um buffer e quando um servidor requisita um token ou mensagem, ele envia o token armazenado em seu buffer. O token escolhido deve seguir uma das disciplina de escalonamento FCFS ou LCFS.

Na figura 7.3, o objeto Fila representa as filas onde os clientes ficam esperando até serem atendidos por um caixa (servidor).

\section{- Representação Gráfica:}

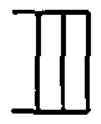

\subsubsection{Servidor}

O objeto Servidor é uma das unidades mais importantes na biblioteca SimTW. Um ou mais servidor, juntamente com uma fila forma um centro de serviço. $O$ servidor é uma entidade capaz de produzir o serviço requerido pelo cliente. Se todos os servidores do centro do serviço estão ocupados quando um cliente entra no sistema, o cliente espera na fila até que um dos servidores fique disponivel. Quando o servidor termina o processamento de um evento, ele envia uma mensagem para sua fila requisitando outro evento para processar.

Na figura 7.3, o objeto Servidor representa os caixas do banco.

- Representação Gráfica:

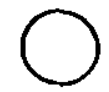




\subsubsection{Saída}

O objeto Saida consome tokens de uma rede de filas. O token (evento), após ser servido, deixa o sistema em um modelo de rede aberta. Esse módulo representa a destruição de tokens em uma rede de fila aberta.

$\mathrm{Na}$ figura 7.3, o objeto Saída representa a saída do cliente do banco.

\section{- Representação Gráfica:}

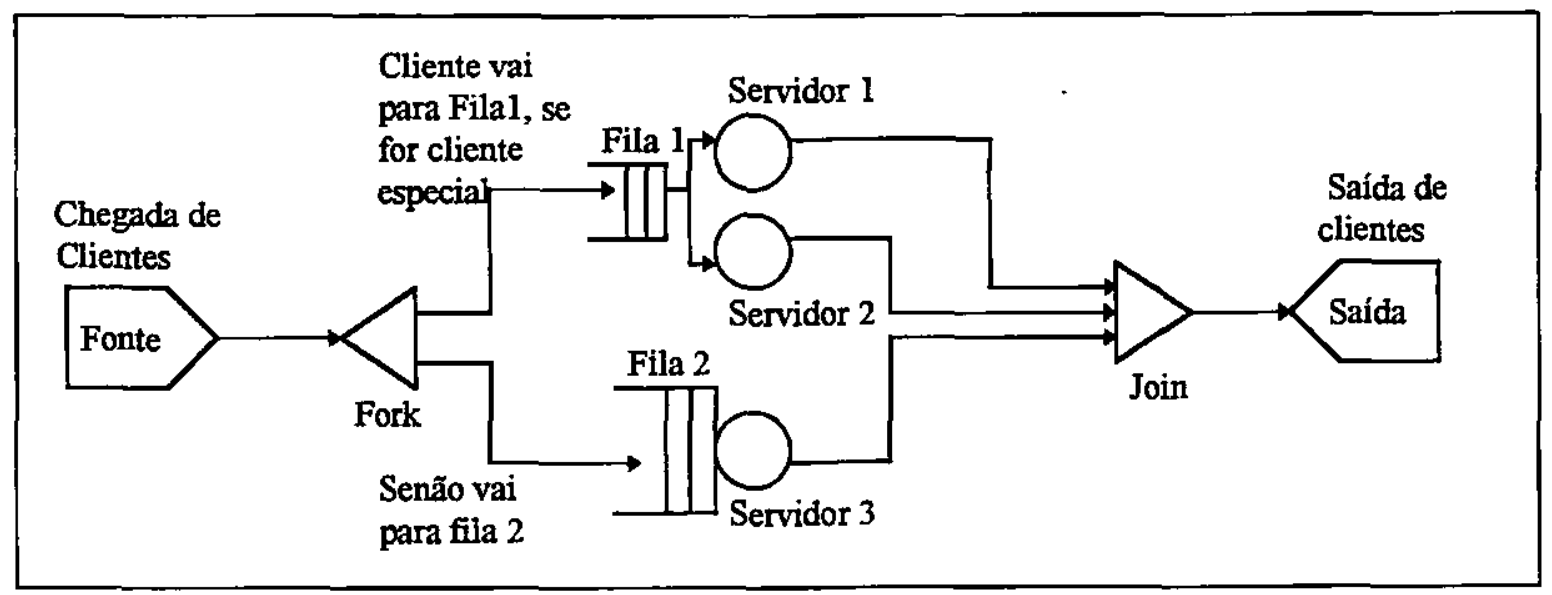

Figura 7.3. Representação gráfica de um sistema Bancário

$\mathrm{Na}$ biblioteca SimTW, cada objeto possui um estado. $\mathrm{O}$ estado de cada objeto é representado por uma definição de classe individual. Esses estados contêm informações, que o sistema necessita relembrar, no caso de ocorrência de rollbacks. A biblioteca SimTW contém as classes FonteEstado, ForkEstado, JoinEstado, FilaEstado, DelayEstado, ServidorEstado e SaidaEstado associados com os seus respectivos objetos.

Informações sobre coleta de estatísticas podem ser incluídas dentro de cada objeto. Atualmente, cada objeto registra apenas o número de eventos que ele processa. Informações adicionais podem ser adicionadas nos códigos de cada objeto. 


\subsection{Instanciação dos Objetos da Biblioteca SimTW}

Esta seção apresenta uma visão mais aprofundada da implementação e funcionamento dos objetos que constituem a biblioteca SimTW.

Uma instância de um objeto Fonte é ativada pelo método FonteObjeto. A função distribuição, a semente (seed) e o tamanho do espaço usado pelo gerador de números aleatórios são especificados através da função setaDistribuicao. $\mathbf{O}$ objeto Fonte recebe um identificador (id) e um nome, os quais devem ser únicos em todo o sistema. $\mathrm{O}$ destino, lugar onde os tokens gerados devem ser roteados, é especificado através do campo destino ao recebe o identificador do objeto destino. $\mathbf{O}$ objeto Fonte recebe um nome através do campo nome. Após o objeto Fonte receber todas essas informações, ele é registrado em um processo lógico. Isso é feito através da função membro registraObjeto. Um exemplo de instanciação do objeto Fonte é mostrado na figura 7.4.

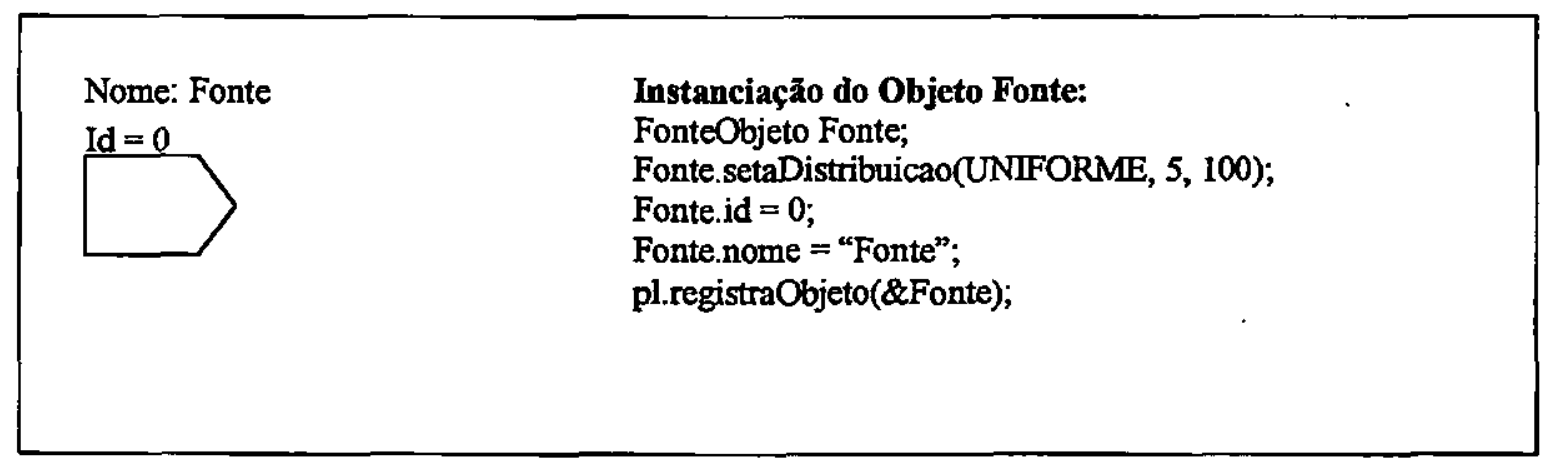

Figura 7.4. Instanciação de um objeto Fonte.

O mesmo procedimento realizado para instanciar o objeto Fonte, também é realizado pelo objeto Fork. $\mathbf{O}$ objeto Fork recebe um identificador (id) e um nome, os quais devem ser únicos em todo o sistema. O fork envia os tokens de entrada para um ou mais destinos. $O$ destino é especificado quando o campo destino recebe o identificador do objeto destino. Um vetor de destinos e o número de destinos são passados através da função membro setaForkDistribuicao. Essa função possui um parâmetro extra. Esse parâmetro extra é a opção que determina como o fork irá rotear os tokens para seus destinos. Dessa forma, ao enviar os tokens a seus destinos, o fork pode 1) enviar um token para todos os destinos, 2) enviar tokens alternativamente para dois destinos, 3) enviar tokens na forma 
round robin, 4) enviar para um destino determinado por alguma outra condição. Esse envio é realizado através da especificação TODOS, ALTERNADO, ROUNDROBIN, CONDICIONAL ou ESPECIAL. A opção ESPECIAL é usado quando o usuário deseja usar um esquema específico de distribuição. Esse esquema específico pode ser qualquer uma das usadas pelo objeto Fonte. Um exemplo de instanciação do objeto Fork é mostrado na figura 7.5.

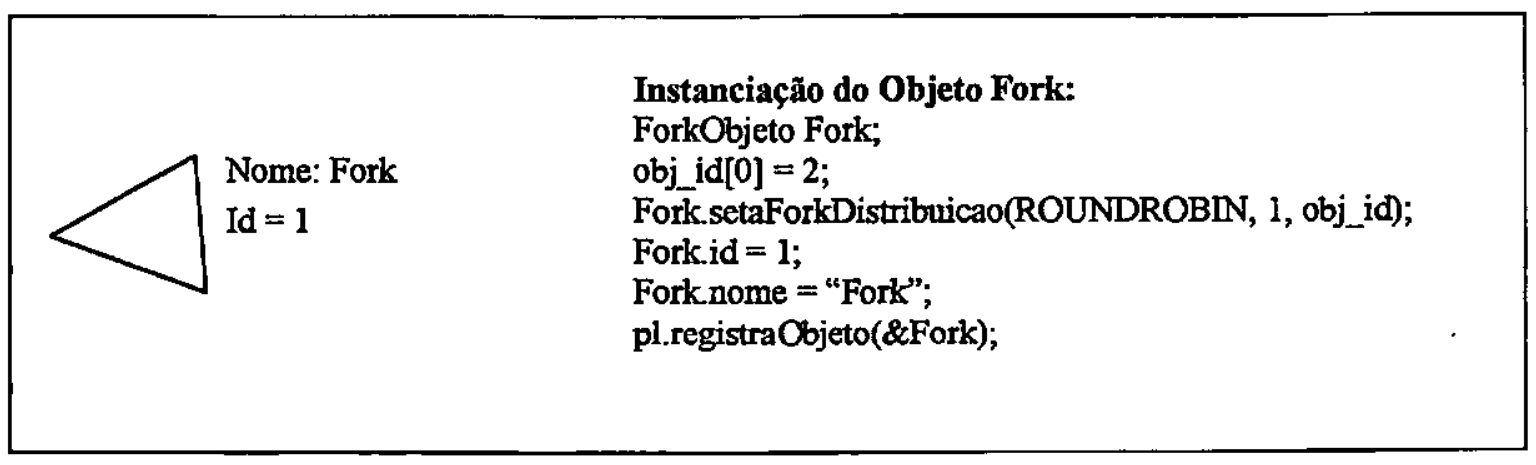

Figura 7.5. Instanciação de um objeto Fork.

$\mathrm{O}$ objeto delay (atraso) é muito similar ao objeto Fonte. $\mathrm{O}$ objeto Delay recebe um identificador (id) e um nome, os quais devem ser únicos em todo o sistema. Ele recebe os tokens de entrada e adiciona um intervalo de atraso ao tempo de chegada dos tokens, enviando-os para o objeto cujo identificador (id) corresponde ao campo destino do objeto delay. $\mathrm{O}$ intervalo de atraso é determinado usando uma das distribuições mencionadas anteriormente. $O$ usuário determina a distribuição, a semente (seed) e o tamanho, usando a função membro setaDelayDistribuicao. Um exemplo de instanciação do objeto Delay é mostrado na figura 7.6.

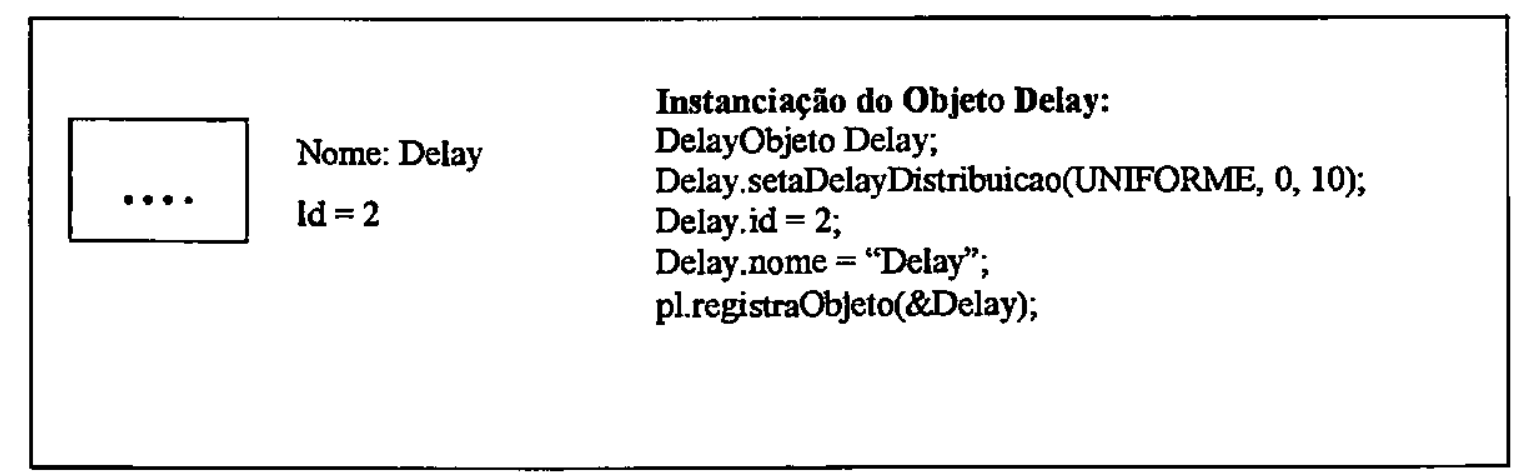

Figura 7.6. Instanciação de um objeto Delay. 
O objeto Fila destina-se a fornecer tokens ao objeto servidor. O objeto Fila pega tokens de vários recursos de Fonte e enfileira as tarefas (jobs) que devem ser processadas pelo servidor. Se a capacidade do buffer é excedida, os tokens extras que chegam são ignorados ou redirecionados. Durante a sua instanciação, o objeto Fila recebe um nome e um identificador (id), os quais devem ser únicos em todo o sistema. Um exemplo de instanciação do objeto Fila é mostrado na figura 7.7.

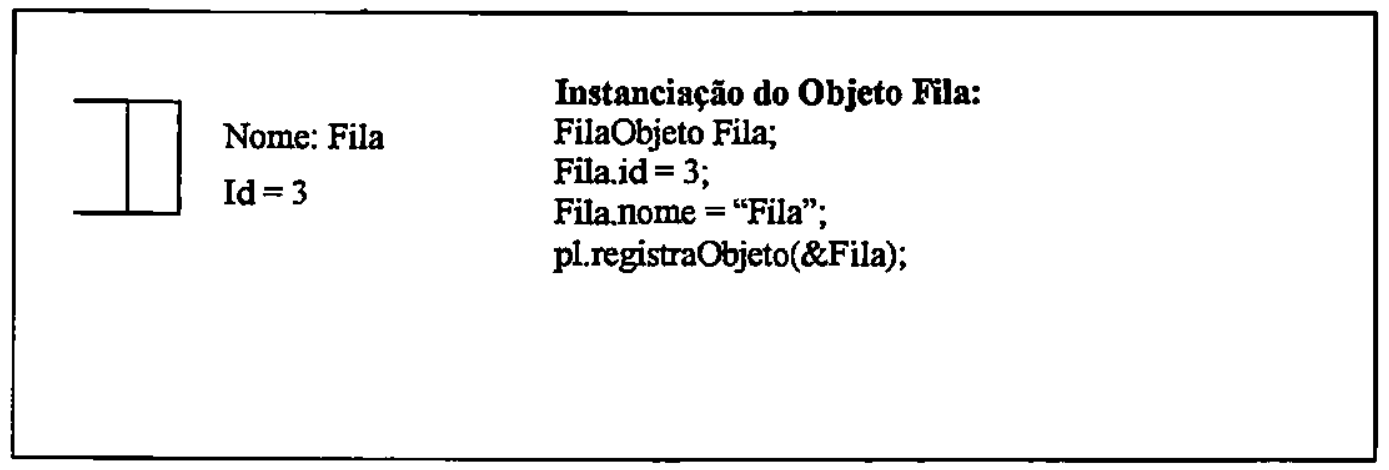

Figura 7.7. Instanciação de um objeto Fila.

O objeto servidor é similar ao objeto Fonte. Ao invés de produzir tokens, ele os processa e, durante esse processamento, um intervalo de tempo, representando o atraso (delay), é adicionado ao tempo de chegada do token. O servidor processa o token e o envia para um objeto especificado através da variável destino. Durante o processamento, o atraso (delay) pode ser modelado usando uma das funções de distribuição citadas anteriormente. A função distribuição, a semente (seed) e o tamanho para o gerador de número aleatório são fornecidos através da função setaServidorDistribuicao. $\mathrm{O}$ objeto Servidor também recebe um nome e identificador (id), os quais devem ser únicos em todo o sistema. Um exemplo de instanciação do objeto Servidor é mostrado na figura 7.8 .

O objeto Join coleta tokens de várias origens, passando-os para um único destino. $\mathrm{O}$ destino é especificado pela variável destino. Quando se deseja enviar um ou mais tokens para um determinado destino, basta o objeto transmissor colocar o identificador do destino na sua variável destino. Um exemplo de instanciação do objeto Join é mostrado na figura 7.9. 


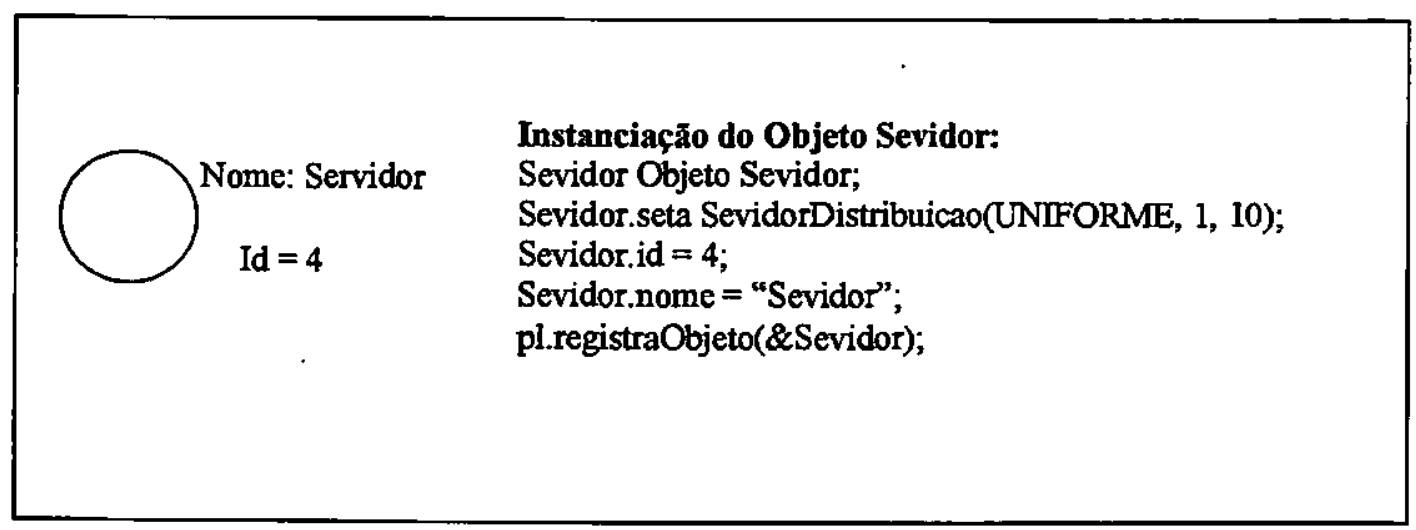

Figura 7.8. Instanciação de um objeto Servidor.

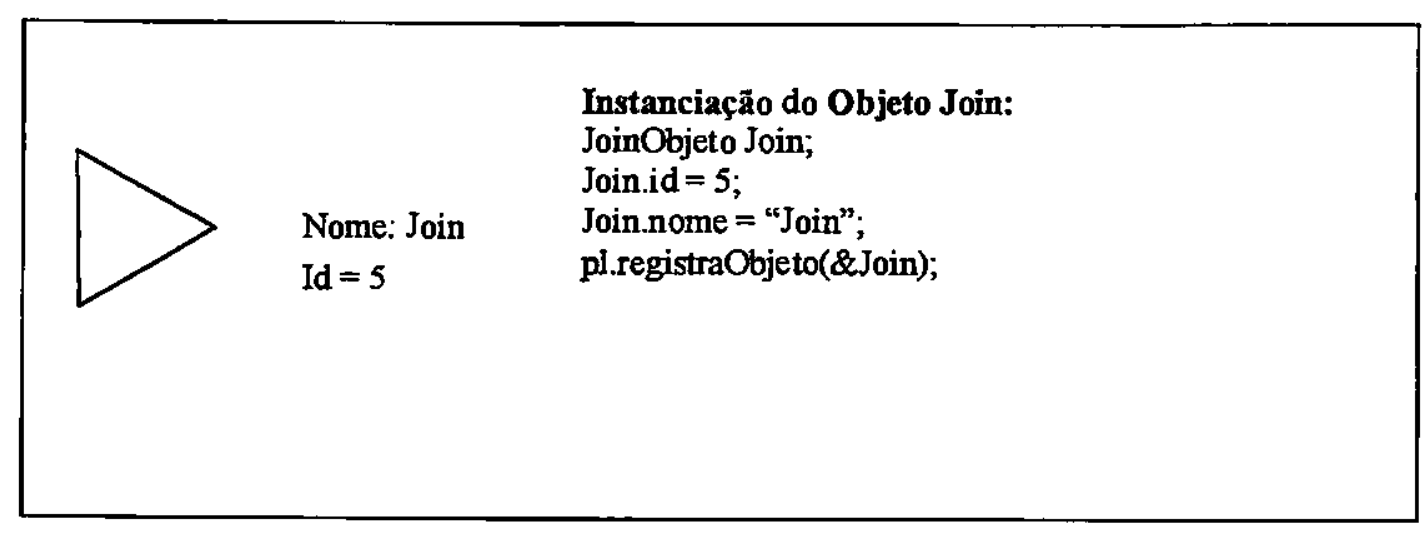

Figura 7.9. Instanciação de um objeto Join.

O objeto Saida representa a saída ou destruição dos tokens no sistema. Durante a sua instanciação, recebe um nome e identificador, únicos em todo o sistema. Um exemplo de instanciação do objeto Join é mostrado na tabela 7.10.

\footnotetext{
Instanciaçăo do Objeto Saida:

SaidaObjeto Saida;

Saidanome = "Saida";

pl.registraObjeto(\&Saida);
}

Nome: Saida $\quad$ Saida.id $=6$;

Id $=6$

Figura 7.10. Instanciação de um objeto Saida. 
Após o registro de todos os objetos em um processo lógico, a aplicação do usuário chama a função todosRegistrados, para verificar se os objetos foram realmente registrados em seus processos lógicos. Depois de realizar essa verificação, faz-se uma chamada à função simula, que determina o início da simulação.

O mesmo procedimento é repetido em outras máquinas. Quando o código é compilado e executado, cada máquina (processo lógico, neste caso) tem que conhecer quais objetos possui e quais objetos estão presentes em outras máquinas ou processos lógicos. Durante o processo de execução, as máquinas envolvidas na execução da simulação trocam mensagens através do PVM.

\subsection{O Sistema Time Warp e a Biblioteca SimTW}

Como explicado no capítulo 6, o sistema STW foi projetado para executar sobre o ambiente de passagem de mensagens PVM, versão 3.3. A biblioteca SimTW, assim como o STW, foi escrita e compilada usando o compilador GNU $\mathrm{CH}, \mathrm{g}+$, versão 2.7.0 Algumas classes pertencentes à biblioteca libg + são utilizadas pelo STW. Se o g+ não se encontra disponível, ele deve ser instalado nos computadores onde os programas serão compilados e a simulação realizada.

A figura 7.11 fornece uma visão de como a biblioteca SimTW interagi com o sistema STW. A biblioteca fornece certos construtores ao STW, solicitando serviços e indicando as mudanças que deseja realizar em alguma classe do STW previamente definida. Por exemplo, se a biblioteca requisitar mudanças nas definições das classes Evento e Estado, ela deve informar ao STW que utilizará uma nova definição para as classes Evento e Estado. As novas definições das classes Evento e Estado podem herdar os métodos e dados pertencentes às suas classes originais.

A camada mais baixa (camada 1) do ambiente para simulação, é formada pelo ambiente de passagem de mensagens PVM. A camada 2 é formada pelo sistema STW. A camada 3 é onde a biblioteca SimTW está localizada. A SimTW encontra-se em uma camada acima do STW, por necessitar de alguns serviços oferecidos diretamente pelo STW, como por exemplo, envio e recebimento de mensagens, ativação de rollbacks, eliminação de mensagens, entre outros. A camada 4 é a camada de aplicação e deve ser fornecida pelo usuário. Essa camada é formada pelo código de programa (aplicação) do usuário. Essa aplicação contém o modelo do sistema de fila que o usuário deseja simular. 
Antes de iniciar uma simulação, deve-se especificar quais máquinas serão envolvidas no processo de execução da simulação. Isso é feito após ativar o Pvm. O comando add nome-damáquina é utilizado para adicionar máquinas na máquina paralela virtual criada através do PVM. Depois de adicionar todas as máquinas necessárias à simulação, o STW é ativado através da aplicação fornecida pelo usuário.

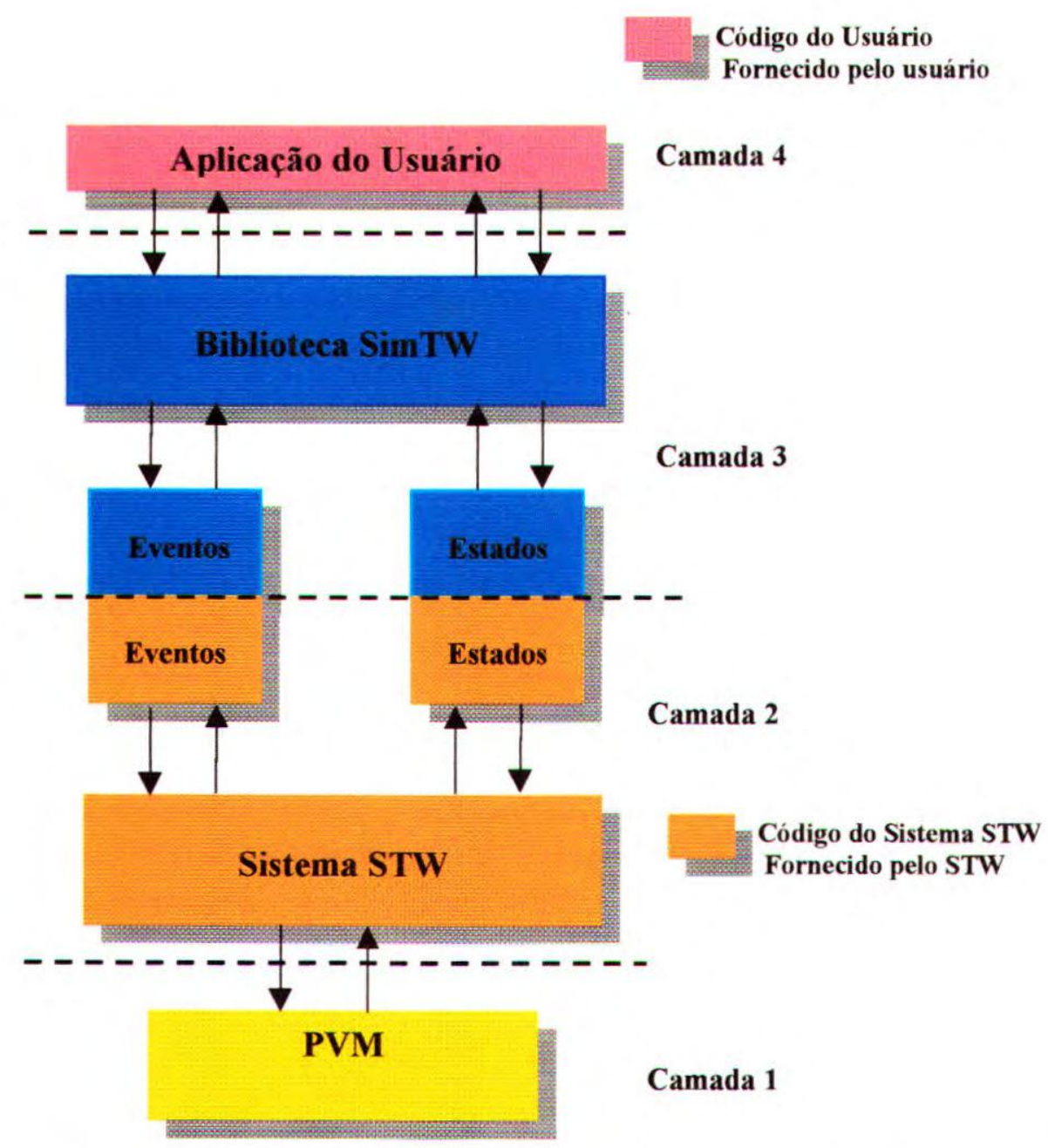

Figura 7.11. Interação entre a Aplicação do usuário, a biblioteca SimTW, o STW e o PVM 


\subsection{Estudo de Caso: STW Como Modelo de Simulação}

Após o desenvolvimento do STW e da biblioteca SimTW, um estudo de caso foi desenvolvido utilizando o STW e a biblioteca SimTW. Esse estudo tem como objetivo analisar o comportamento e validar o sistema Time Warp através da simulação do modelo sobre o cancelamento agressivo e sobre o cancelamento preguiçoso. Visando alcançar esse objetivo, optouse por modelar o próprio sistema Time Warp, utilizando os objetos da biblioteca SimTW.

Descrição do modelo: No STW, os eventos gerados são roteados para a máquinal (servidor1) ou para a máquina 2 (servidor2). Os eventos são enviados para a máquina 1 se o seu campo dest for igual ao tid_pl[0] (dest $=$ tid_pl[0]), a posição 0 do vetor tid_pl indica que os eventos serão processados na máquinal (servidorl), ou são transmitidos para a máquina 2 se o seu campo dest for igual a tid_pl[1] (dest = tid_pl[1]), a posição 0 do vetor tid_pl indica que os eventos serão processados na máquina2 (servidor2). Após a distribuição dos eventos, se o servidor estiver ocupado, esses eventos são armazenados em filas, senão são enviados diretamente para a máquina (servidor) para serem executados. Após os eventos serem processados pelo servidor, eles (os eventos processados) são enviados para o objeto Join, que envia esses eventos para o objeto Saída. $O$ objeto Saida retira os eventos processados do sistema. A ilustração do modelo de rede de filas do STW é mostrado a seguir (figura 7.12).

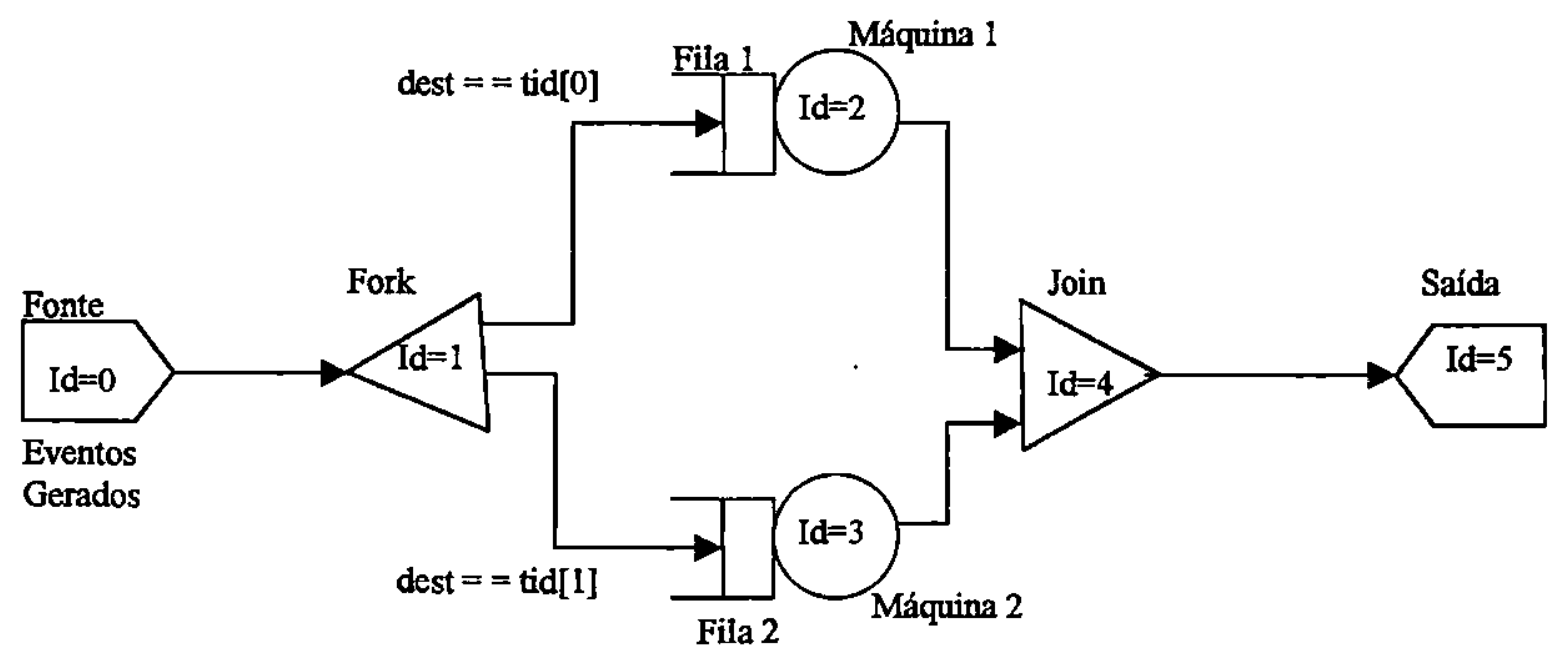

Figura 7.12. Modelo de Rede de Fila do STW. 
Neste modelo, o objeto Fonte é instanciado com identificador igual a zero $(\mathrm{id}=0)$ e o nome Fonte, o nome dos objetos da biblioteca SimTW pode ser qualquer um estabelecido pelo usuário. Os eventos gerados pelo objeto Fonte são passados para o objeto Fork, cujo identificador recebe o valor 1 (id = 1) e o campo nome recebe Fork como nome do objeto. $O$ Fork recebe os eventos do objeto Fonte e os distribui de maneira uniforme (distribuição uniforme) entre as máquinas do STW. Os eventos são roteados aos seus destinos de acordo com a condição imposta pelo sistema Time Warp. Se o evento a ser escalonado possui o campo (dest = tid_pl[0]), então ele segue para o objeto Fila, cujo identificador recebe o valor $2(\mathrm{id}=2)$ e o nome Filal. $\mathrm{O}$ evento fica armazenado na fila, enquanto o servidor estiver ocupado, ao ser liberado, o servidor atende o evento. Neste caso, o identificador do servidor recebe o valor $3(\mathrm{id}=3)$ e o nome Máquinal. Entretanto, se o evento a ser escalonado possui o campo (dest $=$ tid_pl[1]), isso indica que esse evento deve ser enviado remotamente para o objeto Fila localizado em outra máquina. Esse objeto Filla recebe o identificador igual a 4 e nome Fila2. Se o servidor está disponível, ele atende o evento escalonado, senão o evento fica armazenado na Fila2 até o servidor liberar. $O$ atendimento dos eventos pela máquina2 obedece a uma distribuição exponencial . O identificador do servidor recebe valor igual a $5(\mathrm{id}=5)$ e o nome do objeto servidor Máquina2. $\mathrm{O}$ objeto fork reagrupa todos os eventos que já foram processados e precisam deixar o sistema. Esse objeto apresenta um identificador igual a $6(\mathrm{id}=6)$ e nome Join. $O$ objeto Saída representa a saída ou eliminação de eventos no sistema Time Warp. O objeto Saída recebe um identificador com valor 7 e nome Saída.

Através do modelo STW proposto acima, verifica-se que o processo lógico 1 é formado por seis objetos (Fonte, Fork, Fila1, Máquinal, Join e Destino). Já o processo lógico 2 é formado por apenas dois objetos (Fila2 e Máquina2). O sistema possui ao todo oito objetos, seis pertencentes ao processo lógico $1(\mathrm{id}=0)$ e dois pertencentes ao processo lógico $2(\mathrm{id}=1)$. Após o registro de todos os objetos em seus processos lógicos, deve-se iniciar a simulação, realizando uma chamada à função Simula.

Durante a simulação do modelo STW, a chegada dos eventos no sistema obedece uma distribuição exponencial. Os destinos (máquina 1 e máquina 2) são roteados através da distribuição CONDICIONAL, indicando quem tem dest $=$ tid_pl[0] deve permanecer no processo lógico 1 , máquinal, e quem possuir dest $=$ tidpl[1] deve ser enviado ao processo lógico 2 , localizado na máquina2. Os eventos são roteados entre os servidores (máquinal e máquina2) de acordo com uma distribuição uniforme. $\mathrm{O}$ tempo de atendimento dos servidores (máquinal e máquina2) obedece a 
uma distribuição exponencial.

\subsubsection{Implementação do Modelo STW}

A implementação do modelo de Rede de Fila do STW utilizando a biblioteca SimTW foi realizada no laboratório LaSDPC, do grupo de Sistemas Distribuídos e Programação Concorrente, pertencente ao Instituto de Ciências Matemáticas e de Computação (ICMC), da Universidade de São Paulo (USP). Foram utilizadas neste projeto duas máquinas Linux, versão 2.0.30. Ambas particionadas com o Windows95. O ambiente de passagem de mensagens utilizado foi o PVM, versão 3.3. A implementação do modelo de uma rede de fila como a do STW torna-se relativamente fácil, devido à biblioteca SimTW possuir funções pré-definidas destinadas ao modelamento de sistemas de filas. A coleta e análise dos dados são restritos à quantidade de eventos gerados, à quantidade de eventos processados por segundo e o tempo de simulação, utilizando o cancelamento agressivo e o cancelamento preguiçoso. $O$ objetivo da coleta e análise dos resultados não.é avaliar o sistema STW, mas sim analisar o seu comportamento usando as técnicas de cancelamento incorporadas ao STW, validando o sistema desenvolvido neste projeto.

\subsection{Resultados Obtidos}

Esta seção detalha os experimentos conduzidos para avaliar o comportamento do STW, utilizando as técnicas de eliminação de mensagens por Cancelamento Agressivo e por Cancelamento Preguiçoso. Esse experimento levou em consideração três medidas: (i) tempo total de execução (em segundos); (ii) Número de eventos gerados e (iii) total de eventos processados por segundo.

Esses resultados foram obtidos através da execução do modelo STW apresentado na seção 7.6 sobre duas máquinas Linux, utilizando o compilador GNU $\mathrm{C}++, \mathrm{g}++$. Essa aplicação foi testada sobre um processo lógico (execução sequiencial) e sobre dois processos lógicos (execução distribuída). Como resultado da simulação sequiencial do modelo STW, a taxa de processamento ficou em torno de 29.419,75 eventos processados por segundo. Visando facilitar a análise dos resultados, as simulações foram realizadas gerando um número fixo de eventos (500.000). 
As médias do processamento seqüencial foram as seguintes:

- Número de eventos gerados: 500.000;

- Tempo de Simulação (segundos) - Média: 16,9953;

- Eventos processados por segundo - Média: 29.419,75.

Os experimentos distribuidos foram realizados com as seguintes técnicas de cancelamento:

1. Cancelamento Agressivo;

2. Cancelamento Preguiçoso.

A média dos processamentos distribuídos foram as seguintes:

1) Cancelamento Agressivo:

- Número de eventos gerados: 500.000;

- Tempo de Simulação (segundos): 12,567345;

- Eventos processados por segundo: Média de 39.785,78.

O Speedup alcançado pelo STW utilizando o Cancelamento Agressivo foi:

$$
\text { Speedup }=16.9953 / 12.5673=1,35
$$

2) Cancelamento Preguiçoso:

- Número de eventos gerados: 500.000;

- Tempo de Simulação (segundos): 11,636328;

- Eventos processados por segundo: Média de 42.968,43.

O Speedup alcançado pelo STW utilizando o Cancelamento Preguiçoso foi:

$$
\text { Speedup }=16.9953 / 11.6363=1,46
$$

A figura 7.13. apresenta um gráfico com os resultados da execução do modelo de rede de fila STW. 


\section{Comparação entre Tempos de Simulação em Cancelamento Agressivo, Cancelamento Preguiçoso e Seqüencial ( 500.000 eventos gerados)}

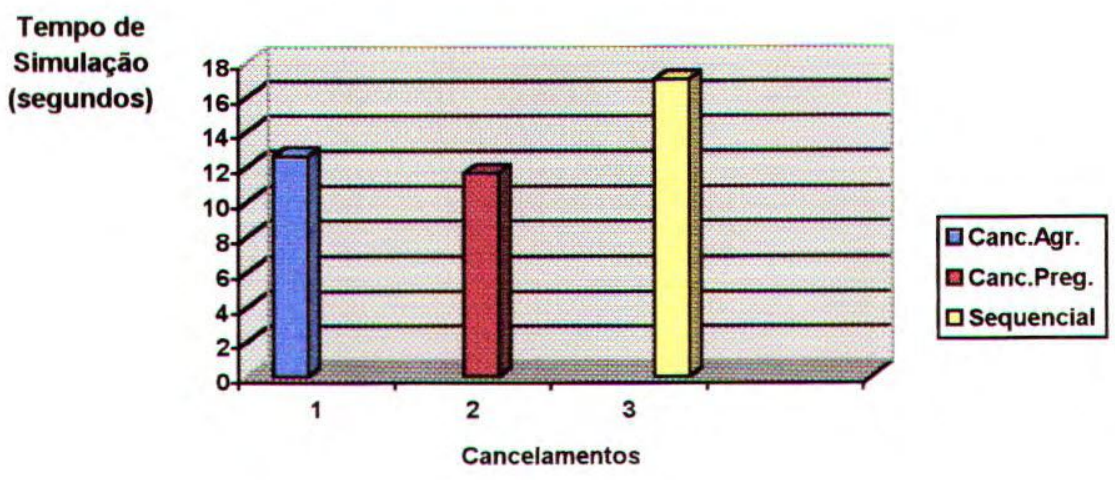

Figura.7.13. Gráfico de Comparação entre Tempos de Simulação do Cancelamento Agressivo, Cancelamento Preguiçoso e Seqüencial.

\subsection{Análise dos Resultados}

Esta seção discute os resultados obtidos durante o experimento do modelo STW. Vale ressaltar que os experimentos realizados sobre o modelo STW destinam-se a uma avaliação comportamental do sistema STW. Essa análise comportamental visa apenas validar e não avaliar o desempenho do sistema Time Warp.

Dentre os resultados obtidos, uma comparação entre o processamento realizado pelo cancelamento preguiçoso com o realizado pelo cancelamento agressivo, merece destaque. Nesse experimento verificou-se que o cancelamento preguiçoso apresenta um desempenho relativamente melhor que o apresentado pelo cancelamento agressivo, cerca de $8 \%$ de ganho de processamento. Esse ganho pode ser explicado através do fato de que o processo que realiza o cancelamento preguiçoso não precisar enviar automaticamente as antimensagens após a detecção de uma violação de causalidade. O cancelamento preguiçoso realiza um rollback para o tempo anterior à ocorrência da violação de causalidade, mas ao invés de enviar sumariamente as antimensagens, ele move os eventos, que estão no período de violação de causalidade, para uma lista mantida por ele. Após o mecanismo de rollback ocorre uma reexecução dos eventos armazenados na lista de entrada. Após a 
reexecução desses eventos, faz-se uma comparação entre os novos eventos gerados e os eventos contidos na lista utilizada pelo cancelamento preguiçoso. Se à comparação for positiva então não será preciso enviar antimensagens, pois a recomputação dos eventos determinou que computação estava correta. Após essa verificação, o conteúdo da lista utilizada pelo cancelamento preguiçoso é removido. Portanto, com a utilização do cancelamento preguiçoso tem-se uma redução do lixo acumulado durante uma execução Time Warp, já que o cancelamento preguiçoso evita uma quantidade relativamente boa de antimensagens. Entretanto, o desempenho do sistema utilizando cancelamento preguiçoso também pode vir a deteriorar, se a probabilidade das novas mensagens geradas ser diferentes das originais for alta.

Verifica-se também que os resultados obtidos com os speedups, média de 1,35 para 0 cancelamento agressivo e 1,46 para o cancelamento preguiçoso, determina que a simulação distribuída de sistemas complexos, como é o caso do STW, é viável e pode apresentar tempo de processamento inferior ao seu equivalente no processamento seqüencial.

\subsection{Considerações Finais}

Neste capítulo foi apresentada a biblioteca SimTW, utilizada para construção de sistemas de filas. Antes de descrever a implementação e os componentes desse sistema, realizou-se uma breve revisão do assunto teoria de filas.

O estudo de caso adotado neste projeto foi o sistema STW. Após a implementação do modelo STW sobre o SimTW, realizou-se uma análise dos dados obtidos, segundo as estratégias de cancelamento agressivo e preguiçoso. Os dados obtidos mostram uma visão do comportamento do STW, visto que não foram realizados testes suficientes para determinar o desempenho do sistema. Dessa forma, a simulação do modelo STW serviu para validar o sistema em questão. 


\section{Capítulo 8}

\section{Conclusões}

Neste capítulo são tecidas algumas considerações relativas ao desenvolvimento deste trabalho, ressaltadas as contribuições relevantes da pesquisa, e comentados os pontos importantes que determinam e estimulam a continuidade desta pesquisa.

\subsection{Considerações Iniciais}

O mecanismo Time Warp é um dos mais importantes protocolos de sincronização de processos em simulação distribuída. No entanto, por apresentar conceitos e regras de funcionalidade relativamente mais complexos que outros protocolos de sincronização, sua implementação e utilização pode, às vezes, degradar ou até mesmo inviabilizar a execução de uma simulação distribuída. Com o intuito de melhorar seu desempenho, divulgar e estimular mais a suạ utilização, várias pesquisas foram e estão sendo realizadas.

Este trabalho apresenta a implementação de um sistema voltado à implementação de programas de simulação. Além dos conceitos primitivos referentes ao Time Warp, foram incorporadas algumas otimizações no ambiente do sistema STW.

\subsubsection{Sistema STW}

Este trabalhou incorporou ao mecanismo original Time Warp algumas otimizações, destinadas a prover uma melhora substancial no desempenho deste protocolo. Um exemplo de otimização implementada é o cancelamento preguiçoso. Além dessa otimização, o mecanismo de cancelamento agressivo também foi embutido no sistema. $O$ cancelamento agressivo é a estratégia de cancelamento 
padrão, seu conceito nasceu junto com a idéia da abordagem Time Warp. As duas estratégias de cancelamento de mensagens - Agressiva e Preguiçosa foram incorporadas ao sistema STW.

O sistema STW é destinado à construção de programas de simulação distribuída. Uma característica marcante do STW é o mecanismo de controle local, suprido pelo rollback, cancelamento agressivo, cancelamento preguiçoso e antimensagens.

O sistema STW apresenta-se em uma camada acima da camada de comunicação formada pelo ambiente de passagem de mensagens PVM. A biblioteca, desenvolvida neste trabalho, situa-se em uma camada acima da camada do STW. Acima da camada SimTW, encontra-se a camada de aplicação, onde o usuário desenvolve suas aplicações.

\subsubsection{Biblioteca SimTW}

A biblioteca SimTw destina-se à construção de sistemas de redes de filas. Essa biblioteca, construída em uma camada acima do STW, utiliza algumas classes e métodos pertencentes ao STW.

O estudo de caso implementado foi a modelagem do STW, e a sua posterior construção sobre utilizando as funções da biblioteca SimTW. Os resultados obtidos com a simulação do modelo STW demonstrou que o cancelamento preguiçoso apresentou uma pequena vantagem no processamento de eventos sobre o cancelamento agressivo. Isso se deve ao fato de que durante a violação de causalidade, o cancelamento preguiçoso não envia de imediato as antimensagens, destinadas à eliminar as mensagens positivas que foram enviadas para o próprio ou outros processos, durante o período de violação de causalidade. Somente após a reexecução dos eventos, se os eventos gerados indicarem que a computação realmente está incorreta, faz-se então o envio das antimensagens. Essa estratégia evita a ocorrência indiscriminada de rollbacks. Entretanto, quanto maior o número de rollbacks, a vantagem do cancelamento preguiçoso sobre o agressivo diminui.' Isso pode ser explicado pelo fato de que ao aumentar o número de rollbacks, torna-se necessária uma computação extra para armazenar os eventos em uma lista utilizada somente pelo cancelamento preguiçoso, e verificar se os eventos gerados após o rollback são iguais aos localizados na lista mantida pelo cancelamento preguiçoso. Porém, os riscos apresentados pelo cancelamento agressivo continuam maiores. Um aumento no número de rollbacks pode levar a um aumento no número de rollbacks 
secundários, o que pode vir a provocar um efeito "cascata" ou efeito "dominó" de rollbacks, degradando o desempenho do sistema.

\subsection{Crítica Bibliográfica}

Existe uma vasta bibliografia sobre modelagem e avaliação de desempenho de sistemas, a maioria delas considerando o estudo das técnicas utilizadas para a solução de modelos. A bibliografia consultada (Adam \& Dogramaci, 1979) (Pegen, 1991) (Soares, 1992) (MacDougall, 1987) (Fishwick, 1995) concentra-se nos aspectos práticos necessários, não apenas para solução, mas também à construção de modelos.

Percebe-se, através da bibliografia consultada, que todos autores evidenciam a crescente utilização da simulação em diversa áreas de aplicação; e que entre os principais fatores que incentivam este crescimento estão o desenvolvimento do hardware e as linguagens de simulação, provocando um redução drástica dos esforços necessários para programar um modelo de simulação.

A flexibilidade é um dos fatores mais importantes para a grande utilização da simulação, segundo a maioria dos autores. Grande parte das outras técnicas, como por exemplo, solução analítica de modelos requer que os problemas encontrados no sistema real sejam transformados em um modelo idealizado em uma estrutura bastante simplificada, levando, às vezes, a uma solução irreal do modelo. A simulação, por outro lado, impõe menos obstáculos para a solução de modelos do sistema real.

O uso generalizado da simulação como uma ferramenta que auxilia o projeto, a validação e avaliação de desempenho de um sistema real (existente ou apenas em projeto) deu origem a uma série de pacotes e linguagens especificamente projetadas para este fim, impondo uma certa estruturação nos modelos e simplificando suas soluções (Soares, 1992).

A computação paralela caracteriza-se pela busca de melhor desempenho através da divisão de uma aplicação para que esta execute em vários elementos de processamento, de maneira que se obtenha um melhor aproveitamento do hardware disponivel. Vários são os fatores que motivaram a computação paralela, podem-se citar: melhor relação custo/beneficio em relação a 
supercomputadores, limitação fisica do aumento de velocidade em processadores e tolerância a falhas (Almasi \& Gottlieb, 1994)(Amorim et al., 1988).

O uso da computação paralela implica na utilização de novos conceitos e novas formas de estruturar hardware e software. Várias arquiteturas de computadores paralelos foram propostas; sendo estas agrupadas em diversas classificações (Flynn, 1972) (Almasi \& Gottlieb, 1994) (Duncan, 1990)(Hwang \& Briggs, 1984). A mais conhecida é a classificação de Flynn (Flynn, 1972), sendo até hoje, vastamente utilizada. Entretanto, uma classificação mais abrangente e completa é apresentada por Duncan (Duncan, 1990). Dentre as arquiteturas paralelas destacam-se as arquiteturas MIMD, em virtude de sua flexibilidade e potencialidade para a execução de algoritmos paralelos de granularidade grossa e média (Blech, 1994). As arquiteturas MMD dividem-se em dois grupos, definidos de acordo com a organização de memória: arquiteturas de memória centralizada e distribuída.

Para a programação em arquiteturas MIMD, vários métodos foram propostos para a ativação e coordenação de processos paralelos. Os métodos de ativação de processos paralelos diferenciam-se basicamente pelos itens flexibilidade e estruturação, de forma que métodos estruturados (cobegin/coend e doall) são menos flexíveis, e métodos flexíveis (fork/join) são menos estruturados (Almasi \& Gottlieb, 1994) (Andrews \& Schneider, 1983) (Kirner, 1989) (Quinn, 1987).

Para a cooperação dos vários processos paralelos, existe a necessidade da implementação de métodos de comunicação e sincronismo. Estes métodos são definidos de acordo com a organização de memória da arquitetura onde os processos são executados: em memória centralizada, utilizam-se variáveis compartilhadas (busy-wayting, semáforos e monitores) (Almasi \& Gottlieb, 1994) (Andrews \& Schneider, 1983) (Tanenbaum, 1998), e para memória distribuída utiliza-se troca de mensagens (comunicação ponto a ponto, rendezvouz e RPC) (Almasi \& Gottlieb, 1994) (Andrews \& Schneider, 1983) (Kirner, 1989).

Várias ferramentas para o desenvolvimento de programas paralelos existem, e dividem-se basicamente em: compiladores paralelizadores, linguagens concorrentes e extensões paralelas (Almasi \& Gottlieb, 1994). Dentre as extensões paralelas destacam-se as plataformas de portabilidade, que relacionam ambientes portáteis para a programação via troca de mensagens (paradigma de troca de mensagens) em arquiteturas paralelas ou ambientes distribuídos (Almasi \& Gottlieb, 1994).

$O$ uso do paradigma de troca de mensagens tem-se difundido na computação, e os ambientes de portabilidade tem-se mostrado uma abordagem eficiente para a implementação deste paradigma 
(Mcbryan, 1994). Várias ambientes foram propostos, entre eles: PVM, Express e MPI (Almasi \& Gottlieb, 1994) (Andrews \& Schneider, 1983) (Kirner, 1989) (Quinn, 1987) (Mcbryan, 1994) (Blech, 1994) (Zaluska, 1991).

Atualmente, considera-se o PVM como o padrão "de fato" para ambientes de portabilidade, por ele ser o mais usado pela comunidade computacional. O PVM é um conjunto integrado de bibliotecas de funções e de ferramentas de software, cuja finalidade é emular um sistema computacional concorrente heterogêneo, flexível e de propósito geral (Beguelin, 1994)(Souza, 1996).

Uma simulação realista requer esforço computacional, e o tempo de processamento paralelo muitas vezes inviabiliza a simulação. Para esses casos, a utilização de simulação distribuída vem, gradativamente, substituindo a simulação seqüencial. A simulação distribuída (Fujimoto, 1990)(Nicol \& Fujimoto, 1995)(Misra, 1986) explora o paralelismo e a alta capacidade de comunicação (Almasi \& Gottlieb, 1994).

Para possibilitar a utilização de diversos processadores na execução de uma simulação é necessário adaptar-se a simulação seqüencial para esta nova realidade. Um problema crítico na simulação distribuída é o sincronismo entre os processos. A simulação seqüencial baseia-se em uma lista de eventos futuros que armazena os eventos a serem executados pela simulação, ordenados pelo tempo em que eles devem ocorrer (MacDougall, 1987). A ativação desses eventos é controlada por um sistema de relógio que controla o tempo da simulação.

As obras consultadas sobre simulação distribuída apontam que o problema desta, está na natureza seqüencial da lista de eventos futuros. Um único evento é retirado da lista para ser executado; podendo, o evento, gerar novos eventos com diferentes localizações na lista. Esse mecanısmo torna dificil a execuçăo conco1ı nte aos eventos, uma vez que a lista de eventos futuros não pode ser simplesmente particionada (Fujimoto, 1990)( Misra, 1986) (Jefferson, 1985) (Candy \& Misra, 1981) (Nicol \& Fujimoto, 1995).

Para solucionar o problema de sincronismo entre os processos de uma simulação distribuída, diferentes protocolos de sincronização têm sido propostos.

O protocolo CMB (proposto por Chandy, Misra e Bryant) nāo utiliza a estrutura sequaencial imposta pela lista de eventos futuros. A execução segue a ordem imposta pelo tempo real do sistema. $\mathrm{O}$ esquema proposto pelo método $\mathrm{CMB}$ garante que um processo só executará um evento quando 
estiver seguro que todos os eventos, cuja execução pode influenciar o evento em questão, já foram processados. Este protocolo é denominado conservativo e baseia-se no bloqueio da execução de eventos. Para evitar a ocorrência de deadlocks devido a este bloqueio, utiliza-se a emissão de mensagens nulas (Fujimoto, 1990)( Misra, 1986).

A utilização de mensagens nulas provoca uma sobrecarga considerável e consequentemente um aumento no tempo de simulação. Para evitar esta sobrecarga, o protocolo Time Warp (proposto por Jefferson e Sowrizral) utiliza um mecanismo otimista para a sincronização dos processos (Jefferson, 1985). Nesse protocolo, assume-se que o próximo evento disponivel no processo em questão pode ser executado. Se após executá-lo, for recebida uma mensagem com tempo anterior, um mecanismo de rollback é acionado, isto é, o estado anterior à execução do evento deve ser recuperado, mensagens cancelando as erroneamente enviadas são transmitidas, o novo evento é executado e então o evento que já tinha sido executado é novamente executado (Jefferson, 1985) (Fujimoto, 1990) (Overeinder et al., 1991).

O mecanismo de rollback pode gerar um grande overhead no sistema. Assim, o objetivo dos diferentes protocolos é minimizar o overhead imposto pela necessidade de sincronização. Um dos problemas dessa minimização é que o melhor protocolo não é sempre o mesmo para diferentes sistemas simulados e para diferentes arquiteturas consideradas.

\subsection{Dificuldades Encontradas}

Durante a realização deste trabalho as principais dificuldades encontradas foram:

- Complexidade dos algoritmos que descrevem o mecanismo otimista Time Warp, dificultando a compreensão e implementação do sistema;

- Complexidade apresentada por alguns algoritmos de otimizações, dificultando a implementação dos mesmos no sistema;

- Gerenciamento de memória devido à sobrecarga na utilização de memória. O mecanismo Time Warp tende a provocar uma sobrecarga de memória, devido às muitas listas que ele deve manter para um provável rollback. 


\subsection{Contribuições Relevantes}

As contribuições mais importantes fornecidas por este trabalho são:

- O sistema STW destina-se à construção de programas para simulação distribuída, utilizando o ambiente de passagem de mensagens PVM. Ele fornece ao usuário uma boa ferramenta à construção de programas para simulação distribuída;

- Um sistema destinado à análise do funcionamento do mecanismo Time Warp. $\mathrm{O}$ usuário que deseja apenas analisar o funcionamento e desempenho do STW, precisa apenas construir um programa que avalie o sistema, sem precisar alterar o código do mesmo;

- Uma biblioteca destinada à construção de modelos de redes de filas. Essa biblioteca fornece objetos (métodos) pré-definidos, tornando a construção de modelos de sistemas de filas uma tarefa mais fácil;

- Geração de um conjunto de classes-base para o mecanismo Time Warp. 0 usuário pode redefinir algumas classes do sistema, como por exemplo, as classes eventos e estados, sem alterar o código do sistema. Essa vantagem foi conseguida através do uso do paradigma de orientação a objetos, tornando o STW estruturalmente modular, facilitando alterações em partes do código, sem ter que alterar toda a estrutura do programa.

- A utilização do STW em outros trabalhos de pesquisa. O sistema STW ainda encontra-se em fase inicial, faz-se necessário a inclusão de novas otimizações, para que o sistema melhore cada vez mais seu desempenho.

\subsection{Trabalhos Futuros}

A abordagem otimista Time Warp tem-se tomado o foco principal em várias linhas de pesquisas no mundo. Algumas dessas pesquisas resultam em boas propostas de otimizações. Por isso, as propostas de trabalhos futuros do STW concentram-se na implementação e inclusão de otimizações. As propostas para trabalhos futuros são:

- Acrescentar novas otimizações: 
- No Gerenciamento de memória para que o sistema faça uma coleta de lixo automática. Nessa coleta, todos os objetos que possuam tempo menor que o estimado pelo GVT são descartados do sistema, levando a um melhor aproveitamento da memória pelo sistema;

- Gerenciamento de Comunicação: Agregação Dinâmica de Mensagens. Essa otimização visa diminuir a quantidade de mensagens enviadas de um processo para outro, diminuindo dessa forma, a sobrecarga gerada por sistema que utiliza muita comunicação interprocessos. A sua proposta é agrupar em um único buffer uma quantidade suficiente de mensagens destinadas a um mesmo processo. Quando o processo transmissor for estabelecer comunicação com o processo receptor, faz-se necessário apenas uma porta de comunicação para enviar o conteúdo do buffer, ao invés das muitas que seriam precisas para transmitir cada mensagem individualmente;

- Cancelamento Dinâmico $\rightarrow$ O sistema escolhe automaticamente, em tempo de execução, qual tipo de cancelamento utilizar;

- Utilizar o sistema STW para construção de novas aplicações, como por exemplo, modelos VHOL, modelos de redes de telecomunicações, entre outros;

- Implementação de um sistema único que integre tanto a abordagem CMB quanto* a abordagem otimista Time Warp (doutorado em andamento). 


\section{Referências Bibliográficas}

ADAM, N.R.; DOGRAMACI, A. Current Issues in Computer Simulation. Academic Press, 1979.

AKYILDIZ, I.F.; CHEN, L.; DAS, S.R.; FUJIMOTO, D.M.; SERFOZO, R.F. Performance Analysis of Time Warp with Limited Memory. ACM SIGMETRICS Conference on Measurement and Modeling Computer Systems, p. 213-224, May 1992.

ALLEN, A. O. Probability Statistic and Queueing Theory - with Computer Applications. Academic Press, 1990.

ALMASI, G. S., GOTTLIEB A. Highly Parallel Computing. $2^{2}$. ed., The Benjamin Cummings Publishing Company, Inc., 1994.

AMORIM, C. L., et al Uma Introdução a Computação Paralela e Distribuida. VI Escola de Computação, 1988.

ANDREWS, G.R.; SCHNEIDER, F.B. Conceps and Notations for Concurrent Programming. $A C M$ Computing surveys, v.15, n.1, mar. 1983.

AZEVEDO, C.M.R. Uma Linguagem de Simulação Distribuida para Transputer. Recife, 1993. Dissertação (mestrado) - Universidade Federal de Pernambuco.

BEGUELIN, A. PVM: Parallel Virtual Machine. A User's Guide and Tutorial for Networked Parallel Computing. The MTT Press, 1994.

BLECH, R.A. An Overview of Parallel Processing (slides). Washington, Parallel Computing with PVM Workshop, 1994. 
BUTLER, R.M.; Lusk, E.L. Monitors, messages and clusters: The P4 parallel programming system. Parallel Computing, v. 20, p. 547-564, 1994.

BRYANT, R.E.. Simulation of Packet Communications Architecture Computer Systems. MIT-LCSTR-188, Massachusetts Institute of Tecnology, 1977.

CENTURION, A.M. Análise de Desempenho de Algoritmos Paralelos Utilizando Plataformas de Portabilidade. Projeto do Grupo de Sistemas Distribuídos e Programação Concorrente, Instituto de Ciências Matemáticas de São Carlos (ICMSC), Universidade de São Paulo (USP), 1997.

CHANDY, K.M.; MISRA, J. Distributed Simulation: A Case Study in Design and Verification of Distributed Programs. IEEE Transactions on Software Engineering, v. SE-S, n.5, p. 440-452, Sep. 1979.

CHANDY, K.M.; MISRA, J. Asynchronous Distributed Simulation Via a Sequence of Parallel Computations. Communication ACM, v.24, n.4, p. 198-205, abr. 1981.

COLLIN, S.M.H. MICHAELIS: Dicionário Prático de Informática. Melhoramentos, São Paulo, 1993.

COULOURIS, G.; DOLLIMORE, J.; KINDBERG, T. Distributed Systems - Concepts and Design. 2a. ed., Addison-Wesley Publishing Company 1994.

CUBERT, R; FISWICK, P. Sim++ Version 1.0. Department of Computer and Information Science and Engineering, University of Florida, USA, Jul. 1995.

DANTAS, C.A.B. Probabilidade: Um Curso Introdutório, Edusp, 1997.

DAS, S.R.; FUJMMOTO, R.M. A Performance Study of the Cancelback Protocol for Time Warp. Workshop on Parallel and Distributed Simulation, p.135-142, San Diego, California, Jul. 1990. 
DUNCAN, R. A Survey of Parallel Computer Architectures. IEEE Computer, p.5-16, Feb. 1990.

EDWARDS, G.;SANKAR, R. Modeling and Simulation of Networks using CSIM. Simulation, v.58, n.2, p.131-136, feb. 1992.

FARIAS, AA; SOARES, J.F.; CESAR, C.C. Introdução à Estatística, Guanabara Koogan S.A, 1991.

FERNANDES, M. Modelagem Analitica de Desempenho de Sistemas Multiprocessadores: Aplicação ao Multiprocessador CPER. São Carlos, 1992. Dissertação (Mestrado) - Universidade de São Carlos.

FERREIRA, AB.H. Minidicionário da Língua Portuguesa. $3^{\text {a }}$ Edição, Nova Fronteira, Rio de Janeiro, 1993.

FERCHAS, A; TRIPATHI, S. K. Parallel and Distributed Simulation of Discrete Event Systems. Computer Simulation - Technical Report - 3336, Department of Computer Systems, University of Maryland, College Park, MD. Aug. 1994.

FLYNN, M.J. Some Computer Organization and Their Efetiveness. IEEE Transactions on Computer, n.21, p.948-60, 1972.

FLOWER, J;; KOLAWA A Express is not just a message passing system. Current and future directions in Express. Parallel Computing, v. 20, p. 597-614, 1994.

FISHWICK, P. (1995, January). Computer Simulation: Growth Through Extension. WWW: Techinical Report, http://www.cs.wm.edu/ subhas/parsim.html.

FOSTER, Y. Designing and Bulding Parallel Programs: Concepts and Tools for Parallel Software Engineering. Addison-Wesley Publishing Company Inc., 1995. 
FRANCÊS, C. R. L. STOCHASTIC FEATURE CHARTS - Uma Extensão Estocástica para os

Statecharts. São Carlos, 1998. Dissertação (Mestrado) - Instituto de Ciências Matemáticas e de Computação (ICMC), Universidade de São Paulo (USP).

FRANCISCO, W. Estatística Básica, Editora UNIMEP, 1993.

FUIIMOTO, R.M. Performance Measurementss of Distributed Simulation Strategies. Transactions of the Society for Computer Simulation. v. 6, n. 2, p. 89 - 132, Apr. 1989.

FUIMOTO, R.M. Parallel Discrete Event Simulation. Comunications of the $A C M$, v. 33, n.10, oct. 1990.

GEIST, A. PIM: Parallel Virtual Machine. MIT Press, Cambridge, Massachusetts, London, England, 1994.

GONÇALVES, RC.M.G. Simulação na Construção de Protótipos de Sistemas Distribuidos. XXII Congresso Nacional de Informática, 1989.

HWANG, K. ; BRIGGS, F.A. Computer Architecture and Parallel Processing. MacGraw-Hill Inc. Computer, 1984.

JEFFERSON, D.R. Virtual Time. ACM Transactions Prog. Lang. Systems, v. 7, n.3, p. 404-425, jul. 1985.

KIRNER, C. Sistemas Operacionais para Ambientes Paralelos. In: IX CONGRESSO DA SBC, Anais da VIII Jornada de Atualização em Informática, 1989.

KIRNER, C. Arquiteturas de Sistemas Avançados de Computą̧ão, In: Jornada EPUSP/IEEE em Sistemas de Computação de Alto Desempenho. Anais. p. 307-353, 1991.

- KLEINROCK, L. Queueing Systems - Volume II: Computer Applications, Wiley-Interscience, 1976. 
LOMOW, G.; CLEARY, J.; UNGER, B.; WEST, D.A. A Peiformance Study of Time Warp. SCS Multiconference on Distributed Simulation, v. 19, n. 3, p. 50-55, jul. 1988.

MAcDOUGALL, M.H. System Level Simulation em Digital System Design Automation: Languages, Simulation \& Data Base. Computer Science Press Inc., p. 1-115, 1975.

MAcDOUGALL, M.H. Simulating Computing Systems Techniques and Tools. The MIT Press, 1987.

MACIEL, P.R.M.; LINS,R.D.; CUNHA, P.R.F. Introdução às Redes de Petri e Aplicações, In: $10^{n}$ Escola de Computação, Campinas, Jul. 1996.

MADISETI, V.; WALRAND, J.; MESSERSCHIMITT, D. Wolf: A Rollback Algorthm for Optimistic Distributed Simulation Systems. Winter Simulation Conference Proceedings, p. 296 - 305, Dec. 1988.

MADISETI; V.; HARDARKER, D.A.; FUJMOTO, R.M. The MIMDIX Operating System for Parallel Simulation SCS Multiconference on Parallel and Distributed Simulation, v. 24, n. 3, p. $65-74$, Jan. 1992.

MARYANSKI, F.J. Digital Computer Simulation. Computing Surveys, v. 18, n. 1, mar. 1986.

MISRA, J. Distributed Discrete-Event Simulation. ACM Computing Surveys, v. 18, n.1, mar. 1986.

MORSELLI Jr., J.C.M. Simulação Distribuida em uma Rede de Transputers Utilizando o Método $C M B$. São Carlos, 1995. Dissertação (Mestrado) - Instituto de Ciências Matemáticas de São Carlos (ICMSC), Universidade de São Paulo (USP). 
MORSELLI Jr., J.C.M.; SANTANA, M.J.; SANTANA, R.H.C.; CALÔNEGO Jr., N. Distributed Simulation Using the CMB Method in a Transputer Network Summer Computer Simulation Conference, p. 144-149, 1996.

MCBRYAN, O.A. An overview of message passing environments. Parallel Computing, v. 20, p. 417-444, 1994.

NAIR, E. A; SAUER, C.H. Elements of Pratical Performance Modeling, Prentice Hall, N. Jersey, 1985.

NAVAUX, P. O. A. Introdução ao processamento paralelo. RBC-Revista Brasileira de Computação, v. 5, n. 2, p.31-43, Out., 1989.

NEWELL, G.F. Application of Queueing Theory - Second Edition, Chapman and Hall, 1982.

NICOL, D.; FUJIMOTO, R.M. (1995, January). Parallel Simulation Today. WWW: Technical Report, http://www.cs.wm.edu/ subhas/parsim.html.

ORLANDI, R. C. G. S. Ferramentas para Análise de Desempenho de Sistemas Computacionais Distribuidos. São Carlos, 1995. Dissertação (Mestrado) - Instituto de Ciências Matemáticas de São Carlos (ICMSC), Universidade de São Paulo (USP).

OVEREINDER, B.; HERTZBERGER, B.; SLOOT, P. (1991,October). Parallel Discrete Event Simulation, http://www.fwi.uva.nl/research/pwrs/archieve/Overeinder91.

PEDGEN, C.D. Introduction to Simulation Using SIMAN. MacGrawHill, 1991.

PRAKASH, A.; SUBRAMARIAN, R. Optimistic Distributed Simulations. 24th Anmunal Simulation Symposium, p. 123-132, Apr. 1991. 
PREISS, B.R.; LOUCKS, W.M. The Impact of Lookahead on the Performance of Conservative

Distributed Simulation. European Multiconference - Simulation Methodologies, Languages and Architectures, p. 204-209, Nuremberg, FRG, Jun. 1990.

PREISS, B.R.; MACINTYRE, I.D.; LOUCKS, W.M. On the Trade-off between Time and Space in Optimistic Parallel Discrete-Event Simulation. Department of Electrical and Computer Engineering, University of Waterloo, Waterloo, Ontario, Canada, 1992.

PREISS, B.R.; LOUCKS, W.M. Memory Management Techniques for Time Warp on a Distributed Memory Machine. Ninth Workshop on Parallel and Distributed Simulation, Lake Placid, New York, Jun. 1995.

QUINN, M.J. Designing Efficient Algorithms for Parallel Computers. MacGrawHill, 1987.

REIHER, P.L.; WIELAND, F; JEFFERSON, D.R. Limitation of Optimism in the Time Warp Operating System. Winter Simulation Conference Proceedings, p. 765-770, Dec. 1989.

REIHER, P.L.; FUJIMOTO, R.M.; BELLENOT, S.; JEFFERSON, D.R. Cancellation Strategies in Optimistic Execution Systems. SCS Multiconference on Distributed Simulation, v.22, n.1, p. 112121, Jan. 1990.

SANTANA, R.H.C.; SANTANA, M.J.; ORLANDI, R.C.G.S.; SPOLON, R., CALÔNEGO Júnior, N. Técnicas para Avaliaçāo de Desempenho de Sistemas Computacionais. Sāo Carlos, ICMSC, 1994. (Notas Didáticas do ICMSC, N 14 ).

SANTANA, M.J.; SOUZA, P.S.L.; SANTANA, R.H.C.; SOUZA, S.R.S. Parallel Virtual Machine for Windows95. Third Euro PVM User's Group Meeting, in Springer Verlag Lecture Notes in Computer Science, Munich, Germany, p. 7-9, Out. 1996.

SAYDAM, T. Process Oriented Languages. Simuletter, v. 16, n. 2, Apr. 1985. 
SHARMA, S.; LAUWRENCE, L.R. Modular Design for Simulation. Software - Pratice and Experience, v.18, n. 10, p. 945-966, 1988.

SOARES, L.F.G. Modelagem e Simulação Discreta de Sistemas, Editora Campus Ltda, 1992.

SOKOL, L.M.; BRISCOE; D.P; WIELAND, A.P. MTW: A Strategy. for Scheduling Discrete Simulation Events for Concurrent Execution. Proceedings of the SCS Multiconference on Distributed Simulation, v.19, n.3, p. 34-42, Jul. 1988.

SOUSA, R Desemvolvimento de uma Extensão Funcional em C para a Construção de um Ambiente de Simulação Orientado a Processo. São Carlos, ICMSC, 1991. (Relatório de Iniciação Científica ICMSC).

SOUZA, P.S.L. Máquina Paralela Virtual no Ambiente Windows. São Carlos, 1996. Dissertação (Mestrado) - Instituto de Ciências Matemáticas de São Carlos (ICMSC), Universidade de São Paulo (USP).

SOUZA, M.A. Avaliação das Rotinas de Comunicação Ponto-a-Ponto do MPI. São Carlos, 1997. Dissertação (Mestrado) - Instituto de Ciências Matemáticas de São Carlos (ICMSC), Universidade de São Paulo (USP).

SOUZA, M.A; SANTANA, R.H.C; SANTANA, M.J. Performance Evaluation of MPI Communication Functions Using Different MPI Implementations in LINUX. SCS Simulation Conference, Atlanta, Georgia, Apr. 1997.

SPOLON, R. Extensão Funcional de Módula 2 para Simulação de Sistemas Discretos. São Carlos, ICMSC, 1992. (Relatório ao CNPq).

STEVENS, W. R UNLX Network Programming. Prentice Hall International Inc., 1990. 
STENNMAN, J.S.; LEE, C.A.; WILSON, L.F.; NICOL, D.M Global Virtual Time and Distributed Synchronization. Workshop on Parallel and Distributed Simulation, p.139-148, Lake Placid, New York, Jun., 1995.

SUNDERAN, V.S.; GEIST, G.A; DONGARRA, J.; MANCHEK, R. The PVM Concurrent Computing System:Evolution, Experiences and Trends. Parallel Computing, v.20, n.4, 1994.

SWAIN, J.J. Simulation Survey: Tools for Process Understanding and Improvement. ORMS Today, Aug. 1995.

TANENBAUM, A.S. Modern Operating Systems, 3². ed., Prentice Hall International Inc., 1998.

TANIR, O; SEVINC, S. Defining Requirements for a Standard Simulation Environment. Computer IEEE, fev. 1994.

TANENBAUM, A.S. Distributed Operating Systems, Prentice Hall International Inc., 1995.

WALKER, D.W. The Design of a Standard Message Passing Interface for Distributed Memory Concurrent Computers. Parallel Computing, v. 20, p. 657-673, 1994.

ZALUSKA E.J. Research Lines in Distributed Computing Systems and Concurrent Computation, Workshop em Programação Concorrente, Sistemas Distribuidos e Engenharia de Software, p. $132-155,1991$. 


\section{Bibliografia Complementar}

ENSLOW, P.H.. Multiprocessors and Parallel Processing. Comtre Corporation, 1974.

KLEINROCK, L. Queueing Systems - Volume I: Theory, Wiley-Interscience, 1975.

KRISHNAMURTHY, E.V. Parallel Processing Principles and Practice. Addison Wesley, 1989.

KWOK, B.T.W.; PREISS, B.R. Simulating Continuos Systems with Piecewise-linear Signals Using Time Warp. International Journal in Computer Simulation, v. 1, n. 1, p.59-79, 1991.

LILJA, D.J. Architectural Alternatives for Exploiting Parallelism. IEEE Computer Society Press, 1992.

LIN, Y.; LOUCKS, W.M; PREISS, B.R; LAZOWSKA, E.D. Selecting the Checkpoint Interval in Time Warp Parallel Simulation. Workshop on Parallel and Distributed Simulation, p. 3-10, San Diego, California, May. 1993.

LIPOVSKI, G.J; MIROSLAW, M. Parallel Computing Theory and Comparisons. WisleyInterscience, 1987.

MORRIS, D.; EVANS, D.G. Modelling Distributed and Parallel Computer Systems. Parallel Computing, n. 18, p. 793-806, 1992.

PREISS, B.R.; LOUCKS, W.M. The Role of Knowledge in Distributed Simulation SCS Multiconference on Distributed Simulation, p. 9-16, San Diego, California, Jan. 1990.

VELDE, E.F.V. Concurrent Scientific Computing. Springer-Verlag, 1994. 